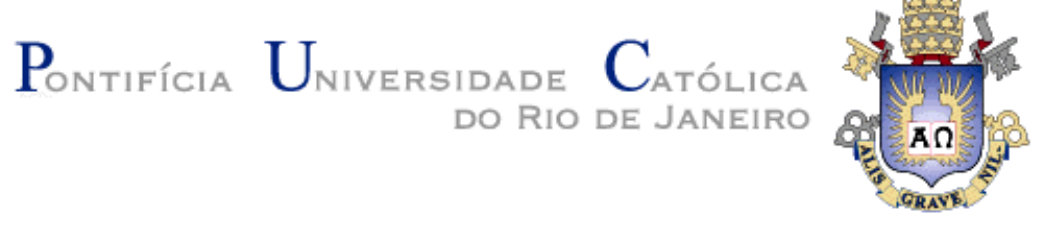

Luciana Dall'Orto Lucena de Souza

\title{
A pessoa com deficiência no Pontificado do Papa Francisco: um olhar misericordioso
}

\author{
Dissertação de Mestrado
}

Dissertação apresentada ao Programa de Pósgraduação em Teologia da PUC-Rio como requisito parcial para a obtenção do título de Mestre em Teologia.

Orientador: Prof. Abimar Oliveira de Moraes 


\title{
Pontifícia Universidade $\mathrm{C}_{\text {atólica }}$

\section{Luciana Dall'Orto Lucena de Souza}

\section{A pessoa com deficiência no Pontificado do Papa Francisco: um olhar misericordioso}

Dissertação apresentada como requisito parcial para obtenção do grau de Mestre pelo Programa de Pós-graduação em Teologia do Departamento de Teologia do Centro de Teologia e Ciências Humanas da PUC-Rio. Aprovada pela Comissão Examinadora abaixo assinada.

\author{
Prof. Abimar Oliveira de Moraes \\ Orientador \\ Departamento de Teologia - PUC-Rio
}

Prof. Cesar Augusto Kuzma

Departamento de Teologia - PUC-Rio

Prof ${ }^{a}$. Arlene Denise Bacarji

Prof. Monah Winograd

Coordenadora Setorial de Pós-Graduação e Pesquisa do

Centro de Teologia e Ciências Humanas - PUC-Rio

Rio de Janeiro, 30 de agosto de 2016 
Todos os direitos reservados. É proibida a reprodução total ou parcial do trabalho sem autorização da universidade, da autora e do orientador.

\section{Luciana Dall'Orto Lucena de Souza}

Graduou-se em Direito pela Universidade Federal do Rio de Janeiro em 1982 e graduou-se em Teologia pelo Centro Universitário Claretiano de Batatais em 2013.

Ficha Catalográfica

Souza, Luciana Dall'Orto Lucena de

A pessoa com deficiência no Pontificado do Papa Francisco: um olhar misericordioso / Luciana Dall'Orto Lucena de Souza ; orientador: Abimar Oliveira de Moraes. - 2016.

$124 \mathrm{f.} ; 30 \mathrm{~cm}$

Dissertação (mestrado)-Pontifícia Universidade Católica do Rio de Janeiro, Departamento de Teologia, 2016.

Inclui bibliografia

1. Teologia - Teses. 2. Deus. 3. Pessoa com deficiência. 4. Pobres. 5. Cultura do encontro. 6. Cultura do descarte. I. Moraes, Abimar Oliveira de. II. Pontifícia Universidade Católica do Rio de Janeiro. Departamento de Teologia. III. Título.

CDD: 200 
Dedico essa Dissertação, todos os esforços, toda a atenção, tudo o que resultou, tudo o que resultará, e todo o meu amor a JESUS DE NAZARE, O FILHO DE DEUS VIVO, a quem pretendo seguir até o fim dos meus dias. 


\section{Agradecimentos}

A Deus, a Nossa Senhora, a São Miguel Arcanjo e a sua Milícia, a São José, ao meu Anjo da Guarda e a todos aqueles que no céu me protegem, inclusive meus pais que lá estão.

Ao Professor Abimar Oliveira de Moraes, pois a leitura indicada me fez entender a profundidade das palavras que tomam sentido segundo uma ordem.

À PUC-Rio, a CAPES, pelos auxílios concedidos.

A todos os professores e funcionários do Departamento pelos ensinamentos e pela ajuda, em especial ao funcionário Sergio Albuquerque pelo profissionalismo exemplar.

Aos amigos e em especial ao Jean e ao Valdo pelo convívio ao longo dos anos que nos possibilitam dizer que somos de fato amigos.

A Margarida e as "Preciosas" pela companhia e amor incondicionais. 


\section{Resumo}

Souza, Luciana Dall'Orto Lucena de; Moraes, Abimar Oliveira de (Orientador). A pessoa com deficiência no pontificado do Papa Francisco: um olhar misericordioso. Rio de Janeiro, 2016. 124p. Dissertação de Mestrado - Departamento de Teologia, Pontifícia Universidade Católica do Rio de Janeiro.

As pessoas com deficiência são pessoas fantásticas porque elas são “doadoras" e não "sugadoras". Elas podem nos ensinar a viver uma vida de felicidade e alegria apesar do sofrimento. Papa Francisco é consciente de que o sofrimento está relacionado com a "cultura do descarte". É por isso que ele sempre lembra a todos que ouçam as vozes de nossos irmãos e irmãs que são pobres, doentes, marginalizados. Ele deseja promover a "cultura do encontro" porque a "cultura do encontro" é o oposto da "cultura do descarte" cujas vítimas são precisamente as pessoas mais frágeis e vulneráveis. Olhar o mundo pelas lentes do encontro é perceber a presença de Deus que é misericordioso e que nos precede no amor. Papa Francisco nos encoraja no sentido de que sejamos para as pessoas com deficiência como Bons Samaritanos, e tenhamos para com essas pessoas solidariedade, caridade e misericórdia. Ele diz que nós não devemos ter medo de abrir as portas e sair para o "encontro" servindo com amor e ternura especialmente às pessoas com deficiência porque elas são recursos de humanidade.

\section{Palavras-chave}

Deus; pobres; pessoa com deficiência; "cultura do encontro"; "cultura do descarte"; solidariedade; caridade; misericórdia 


\section{Abstract}

Souza, Luciana Dall'Orto Lucena de; Moraes, Abimar Oliveira de (Advisor). The disabled people in Pope Francis'Pontificate: a merciful look. Rio de Janeiro, 2016. 124p. MSc.Dissertation - Departamento de Teologia, Pontifícia Universidade Católicado Rio de Janeiro.

The disabled people are great persons because they are givers and not takers. They can teach us to live a life with joy and laughter in spite of the pain. Pope Francis is conscious that the cause of the pain has to do with a "throw-away culture". That is why he always reminds everybody to hear the voices of our brothers and sisters who are poor, sick, marginalized. He wants to promote the "culture of encounter" because the "culture of encounter" is the opposite of the "throw-away culture" whose victims are precisely the weakest and most fragile human beings. To see the world through the lens of encounter is to realize a presence of a merciful God who first encounters us in love. Pope Francis encourages us to take the disabled person on as "Good Samaritans", with solidarity, charity and mercy. He says that we don't have to fear of opening the doors and going out to encounter, serving with love and tenderness especially the disabled people because they are true resources of humanity.

\section{Keywords}

God; poor; disabled people; "culture of encounter"; "throw-away culture"; solidarity; charity; mercy 


\section{Sumário}

1. Introdução 10

2. Um encontro com Bergoglio e com Francisco 13

2.1. A concepção da cultura do encontro em Bergoglio 14

2.1.1. A dignidade humana com vistas a pessoa com deficiência $\quad 15$

2.1.2. O caminhão de lixo como símbolo cultura do descarte 17

$\begin{array}{lr}\text { 2.1.3. A misericórdia divina } & 19\end{array}$

2.1.4. Uma lgreja pobre para os pobres 20

2.2. A apresentação e ponderações sobre a pessoa de Francisco 22

2.2.1. O autorretrato 24

2.2.2. Socci: um crítico contundente 31

2.2.3. Boff e Kasper: defensores ardorosos 34

2.3. Alguns pontos fundamentais da teologia de Francisco 36

2.3.1. A opção preferencial pelos pobres 38

$\begin{array}{ll}\text { 2.3.2. A dignidade humana } & 40\end{array}$

2.3.3. A cultura do descarte 43

3. Misericórdia: um dos pontos centrais da teologia de Francisco 48

3.1. Misericórdia: um coração para o mísero 49

3.2. A ternura como benevolência da misericórdia divina 53

3.2.1. A misericórdia divina na ternura paternal $\quad 55$

3.2.2. A misericórdia divina na ternura maternal 57

3.2.3. A misericórdia divina na ternura das carícias: o perdão 58

3.3. A misericórdia humana: sabedoria do coração 61

3.3.1. Sabedoria do coração é servir ao irmão 65

3.3.2. Sabedoria do coração é estar com o irmão 67

3.3.3. Sabedoria do coração é sair de si ao encontro do irmão 67

3.3.4. Sabedoria do coração é ser solidário com o irmão sem o julgar 70

3.4. A Igreja da Misericórdia

3.5. O Jubileu Extraordinário da Misericórdia 74

4. A pessoa com deficiência: o encontro com Francisco 77

4.1. A pessoa com deficiência: recurso de humanidade 78

4.1.1. Victor E. Frankl: a busca de sentido para o sofrimento 79

4.1.2. Olivia Byington: a inclusão e a diversidade 82

4.1.3. Jean Vanier: a fraternidade e o encontro 84

4.1.4. A ressonância do pensamento cultural na pessoa de Francisco 88

4.2. O encontro de Francisco com a pessoa com deficiência 95

$\begin{array}{lr}\text { 5. Conclusão } & 107\end{array}$

$\begin{array}{lr}\text { 6. Referências Bibliográficas } & 110\end{array}$ 


\section{Abreviaturas}

$A L$ - Exortação Apostólica Pós- Sinodal Amoris Laetitia

EG - Exortação Apostólica Evangelii Gaudium

LF - Carta Encíclica Lumen Fidei

LS - Carta Encíclica Laudato Si

MV - Bula de proclamação do Jubileu Extraordinário da Misericórdia Misericordiae Vultus 


\section{1 \\ Introdução}

No ano de 2013 após a surpresa da renúncia do Papa Bento XVI o mundo se viu frente à outra surpresa: um cardeal argentino, jesuíta, eleito Papa.

Afinal, quem seria o novo Papa? Como seria o seu Pontificado? Pois tendo em vista a origem latino-americana do Papa eleito, em descontinuidade com o padrão europeu vigente, sendo ele o primeiro Papa da América do Sul, tal questionamento se impunha.

Essa pergunta, feita em março de 2013, alavancou o tema dessa Dissertação que tem em Francisco seu princípio basilar, condutor, norteador e principal referencial bibliográfico.

Além disso, sempre houve uma preocupação pessoal com a pessoa com deficiência, tendo em vista a convivência próxima com essas pessoas, cuja valorização é praticamente inexistente, embora sejam pessoas de grandeza ímpar.

Foi pensando nesse quadro que nasceu a intenção de conjugar o pensamento de Francisco com a realidade vivida pelas pessoas com deficiência, uma vez que seu Pontificado está fortemente comprometido com a realidade de exclusão, sofrimento e abandono dessas pessoas, as quais Francisco nomeia como recursos de humanidade, mas que, ainda assim, são vítimas do que ele chama de "cultura do descarte".

É preciso que se diga que escrever sobre Francisco é uma empreitada que se apoia no próprio Francisco, em razão de que seu Pontificado é recente. Por isso, em nossa pesquisa valemo-nos principalmente de suas Encíclicas, Exortações Apostólicas, de suas Homilias e de seu Magistério. Para além disso, há uma escassa bibliografia sendo que a maior parte do que foi escrito, diz respeito aos seus primeiros dias ou meses de Pontificado.

Francisco se preocupa com aqueles que estão à margem da sociedade e conclama a todos para que saiam ao encontro dessas pessoas mais vulneráveis: um êxodo de si na direção dos mais frágeis. O êxodo de si se radica em um coração misericordioso, fraterno e solidário, que está atento ao clamor dos mais pobres. 
Assim sendo, o coração se abre e se torna próximo do irmão que sofre, favorecendo a "cultura do encontro", que para Francisco é de suma importância, pois é por meio dessa cultura que se dá a promoção humana.

Nessa dissertação, portanto, damos destaque ao que para Francisco é de valor inestimável: a opção pelos pobres, aqui representados pelas pessoas com deficiência; a misericórdia a que todos somos chamados para com essas pessoas, e ao encontro, uma vez que elas também são chamadas a ser protagonistas de uma cultura que a todos abrace, qual seja, a cultura do encontro.

A dissertação se divide em três capítulos e em cada qual se apresentam os pontos fundamentais de sua doutrina: o primeiro capítulo fará referência à opção fundamental pelos pobres; o segundo capítulo se remeterá à questão da misericórdia e o terceiro capítulo desenvolverá o tema da "cultura do encontro".

O primeiro capítulo será aquele em que vai se descortinar a pessoa e a Teologia de Francisco. Para tanto, o próprio Francisco tem voz própria, pois é por meio de suas palavras e de seu Magistério que podemos saber quem ele é.

Antes porém, nos debruçaremos sobre o que foi o Arcebispado do Cardeal Jorge Mario Bergoglio em Buenos Aires, elucidando alguns pontos nevrálgicos de sua práxis teológico-pastoral, no sentido de demonstrar que Francisco, em seu Pontificado, tem enfim a chance de colocar em ato, pensamentos e desejos que sempre o acompanharam.

O segundo capítulo buscará esclarecer uma das chaves exponenciais de seu Pontificado: a misericórdia. Deus é misericórdia e o mundo está carente da misericórdia de Deus. Em razão dessa carência Francisco põe em destaque a misericórdia divina e promove o Ano Santo da Misericórdia, clamando a todos para que se voltem para o irmão que sofre, com ternura semelhante à ternura divina, nos moldes da sabedoria do coração.

No terceiro capítulo destacaremos uma das características da pessoa de Francisco, que é exatamente a de conseguir captar o clamor do povo, no sentido de que seus desejos e seus questionamentos ressoam na pessoa de Francisco, que tem o dom de processá-los e de retransmiti-los, tornando-se, assim, voz maior de vozes menores. 
Nesse sentido nos remeteremos ao pensamento de pessoas que conviveram e convivem com pessoas com deficiência, cujo contributo individual, em Francisco, ganha o mundo, com forte possibilidade de se enraizar nas culturas. É também nesse exato momento, que Francisco se encontrará com as pessoas com deficiência, pois nesse capítulo se destacam as homilias e discursos papais em prol dessas pessoas, a quem Francisco dirige um olhar misericordioso, destacando que essas pessoas são vistas como aquelas pessoas que são postas de lado, em uma cultura de descarte e de indiferença; pessoas que sua Igreja quer abraçar, promovendo assim a cultura do encontro.

Por todo o exposto, essa Dissertação terá o seguinte título: A pessoa com deficiência no Pontificado do Papa Francisco: um olhar misericordioso. 


\section{2 \\ Um encontro com Bergoglio e com Francisco}

O atual e primeiro Papa latino americano e Bispo de Roma foi eleito em um momento em que, para uma grande maioria daqueles que compõem o cenário eclesial, e também para aqueles que de fora o acompanham, mudanças são necessárias.

Esse desejo de conversão teológico pastoral tem em Francisco a possibilidade de se realizar. Francisco abraça esse Pontificado tido como renovador trazendo na bagagem um pensamento inovador, fruto de um trabalho pastoral que tem suas raízes nas periferias argentinas, de onde já demonstrava forte reação em relação ao que entendia ser uma violação da dignidade humana onde os excluídos eram considerados como "sobras".

Destarte, esse primeiro capítulo tem dois objetivos: o primeiro é dar a conhecer alguns aspectos teológico-pastorais do arcebispado de Jorge Mario Bergoglio em Buenos Aires, fruto de sua experiência sacerdotal na Argentina. Faz-se necessário dar esse "passo atrás", pois, conhecer Bergoglio é conhecer Francisco. O segundo objetivo é apresentar Francisco, sua pessoa e alguns pontos fundamentais de seu pontificado.

A fim de apresentar Bergoglio e Francisco, estruturamos o presente capítulo em três partes. A primeira parte será dedicada a discorrer sobre alguns vetores preponderantes que compuseram a ação pastoral de Bergoglio em Buenos Aires.

A segunda parte será dedicada a apresentar a pessoa de Francisco em uma apresentação que se desvela a partir dele próprio. Nesse sentido uma espécie de autorretrato ajudará a esclarecer quem é e o que pensa o Bispo de Roma. A apresentação de Francisco traz o relato de sua escolha em relação ao sacerdócio, seus anseios e receios, seus pensamentos e sua identidade quando responde a pergunta sobre quem ele é. Em seguida, nossa atenção se volta para críticas tanto negativas quanto positivas, que representam a opinião de algumas pessoas sobre o seu Pontificado.

A terceira parte será dedicada ao pontificado de Francisco, a fim de demonstrar alguns pontos fundamentais da visão teológico-pastoral que delineia o seu Magistério. A partir daí, fica nítida a perfeita continuidade que há entre o pontificado de Francisco e o Arcebispado de Jorge Mario Bergoglio. 


\section{1 \\ A concepção da cultura do encontro em Bergoglio}

A "cultura do encontro" com o "Deus das surpresas", 1 que se encontra no caminhar e que favorece o encontro com seu povo, ${ }^{2}$ é um tema marcantemente "bergogliano". Um encontro que tem o condão de ser experiencial, conduzindo o homem para um encontro maior que o conduz a vida plena; ${ }^{3}$ um encontro que se estabelece entre os homens e seus pares; um encontro que acontece entre os homens e um Deus que se deixa encontrar.

Em face da amplitude desse encontro, Bergoglio entende que se deve educar a todos para a cultura do encontro, pois é daí que se começa a construção de um mundo melhor, dando lugar a uma sociedade fraterna e solidária. ${ }^{4}$ Portanto, há que se proporcionar espaços, para que esse encontro educativo aconteça, sendo a cidade um lugar propício, uma vez que Deus vive na cidade. ${ }^{5}$

$\mathrm{Na}$ dimensão do encontro educativo cabe dizer que há alguém que precede e já conhece a melhor forma de dinamizar esse encontro; é aquele que conhece o caminho e o indica àquele que se deixa conduzir. Nesse caminho de dupla mão

\footnotetext{
${ }^{1}$ De acordo com Spadaro "O Deus de Bergoglio é (...) o Deus das surpresas". (Cf. SPADARO, A., A proposta do Papa Francisco. O futuro rosto da Igreja. São Paulo: Loyola, 2013, p. 42).

2 Ao se referir a Deus que se deixa encontrar Bergoglio afirma como se segue: "El Dios del encuentro que sale al encuentro de su pueblo. El Dios que - voy a usar una palabra linda de la diócesis de San Justo: el Dios que pone a su pueblo en situación de encuentro". (Cf. BERGOGliO, J. M., Desgrabación de la homilía del Cardenal Jorge Mario Bergoglio s.j. en ocasión de la misa de clausura del Encuentro 2012 de Pastoral Urbana Región Buenos Aires, 02 de setembro de 2012. Disponível em: <http://www.arzbaires.org.ar/inicio/homiliasbergoglio.html >. Acesso em 29 de maio de 2016).

3 "La Vida Plena requiere que el Encuentro se establezca y perdure, superando las rupturas generacionales. (...) La Vida Plena nos pide trabajar por instaurar una cultura del encuentro". (Cf. BeRgoglio J. M., Propuesta de Aparecida para la Pastoral de la Iglesia en Argentina, 15 de junho de 2009. Disponível em: <http://www. www.arzbaires.org.ar/inicio/homiliasbergoglio.html>. Acesso em 25 de maio de 2016).

${ }^{4}$ Cf. BERGOGLIO, J. M., O Verdadeiro poder é o serviço. São Paulo: Ave-Maria, 2013, p. 79.

${ }^{5}$ Nesse sentido assim se pronuncia Bergoglio: "La ciudad brilla como lugar de encuentro. La fe nos enseña que Dios vive en la ciudad, en medio de sus alegrías, anhelos y esperanzas, como también en sus dolores y sufrimientos. Las sombras que marcan lo cotidiano de las ciudades, violencia, pobreza, individualismo y exclusión, no pueden impedirnos que busquemos y contemplemos al Dios de la vida también en los ambientes urbanos. Las ciudades son lugares de libertad y oportunidad...En ellas las personas tienen la posibilidad de conocer a más personas, de interactuar y convivir con ellas...En las ciudades es posible experimentar vínculos de fraternidad, solidaridad y universalidad. En ellas el ser humano está llamado a caminar siempre más al encuentro del otro, convivir con el diferente, aceptarlo y ser aceptado por él".(Cf. BerGOGLIO J.M., Palabras Iniciales Del Sr. Arzobispo En El Primer Congreso Regional De Pastoral Urbana Dios Vive En La Ciudad, Buenos Aires, 25 de agosto de 2011. Disponível em: <http://www.arzbaires.org.ar/inicio/homiliasbergoglio.html>. Acesso em 25 de maio de 2016).
} 
começa a ter lugar à cultura do encontro e nesse processo, tanto aquele que ensina como aquele que aprende, acaba por se conhecer e se perceber com mais clareza, pois há uma troca mútua que os aperfeiçoa e os purifica ${ }^{6}$. A esse caminhar que dá sentido e que estabelece metas e objetivos Bergoglio chama de "educar na cultura do encontro". 7

$\mathrm{O}$ educar no encontro se faz imprescindível para que haja um respeito às diferenças, e para tanto requer como cláusula obrigatória o "êxodo de si" manifesta a compaixão que o homem tem pelo sofrimento do outro, que recolhido em sua dor sente a força esmagadora da solidão. Por isso diz Bergoglio: "Permito-me abrir uma proposta: necessitamos gerar uma cultura do encontro". 9

\subsection{1}

\section{A dignidade humana com vistas à pessoa com deficiência}

Bergoglio defende a dignidade da pessoa humana em chave de proximidade $^{10}$, tendo como objetivo fazer com que os homens se aproximem daqueles que sofrem a indiferença e a exclusão.

Cada ser humano é único, singular e importante, "nem uma só violação a dignidade da mulher ou do homem pode justificar-se em nome de nenhuma coisa ou ideia" ${ }^{11}$, pois essa dignidade é dada por Deus junto com a própria vida.

A dignidade se diz das coisas absolutas, porque dignidade significa que alguém ou algo é valioso por si mesmo, mais além de suas funções ou de sua utilidade para outras coisas. Dali que falemos da dignidade da pessoa, de cada pessoa, além de que sua vida física seja apenas um frágil começo ou esteja a ponto de apagar-se como uma chamazinha. Por isso, falamos da dignidade da pessoa em todas as etapas e dimensões de sua vida. Quanto mais frágeis e vulneráveis forem às condições de vida da pessoa, mais digna é de ser reconhecida como valiosa. E tem de ser ajudada, querida, defendida, promovida em sua dignidade. E isso não se

\footnotetext{
${ }^{6}$ Cf. BERGOGLIO, J. M., $O$ Verdadeiro poder é o serviço, p. 82.

${ }^{7}$ Cf. BERGOGLIO, J. M., O Verdadeiro poder é o serviço, p. 67.

${ }^{8}$ Ibid. p. 84.

${ }^{9}$ BERGOGLIO, J. M., Caminhando para a maturidade. Reflexões sobre a família e a educação. São Paulo: Ecclesiae, 2014, ebook Kindle, loc. 1518.

10 "Cómo podemos favorecer que se manifieste y se proteja, cada vez más, esa dignidad humana tantas veces pisoteada, explotada, disminuida, esclavizada? La categoría clave es la de "projimidad". (Cf. BERGOGLIO J. M., Homilía del Arzobispo de Buenos Aires en la Misa de Clausura del Congreso Nacional de Doctrina Social de la Iglesia, 8 de maio de 2011.

Disponível em: <http://www.arzbaires.org.ar/inicio/homiliasbergoglio.html>. Acesso em $14 \mathrm{de}$ maio de 2016).

${ }^{11}$ Cf. BERGOGLIO, J. M., O verdadeiro poder é o serviço, p. 120.
} 
negocia. (...) A dignidade de ter um valor absoluto como pessoa nos foi dada por Deus junto com a própria vida ${ }^{12}$.

As pessoas com deficiência são aquelas cujas condições de vida e saúde, geralmente são frágeis e vulneráveis. Por isso, sua dignidade deve ser querida, defendida e promovida conforme atesta Bergoglio.

Ele assevera que a família é a primeira a valorizar a dignidade dos seus componentes, principalmente os doentes, frágeis e marginalizados, aceitando-os como são sem qualquer interesse outro, sendo o ambiente familiar um lugar de amor e de diálogo, onde pessoas se sacrificam pelos outros, sobretudo pelos mais frágeis e débeis. Caso essas relações não sejam amorosas há um fechamento que exclui.

Não é possível formar um povo, sentir-se próximo de todos, dar atenção aos mais distantes e excluídos, abrir-se a transcendência, se no coração estão fraturadas estas relações básicas. Desde esta centralidade amorosa da família pode o homem crescer e amar, abrindo-se a todas as periferias, não somente sociais senão também as de sua própria existência ${ }^{13}$.

Obviamente para Bergoglio a tarefa de inclusão de pessoas com deficiência, como qualquer outra tarefa, passa pelo caminho do encontro. No caso em questão é mister buscar auxílio com os familiares e com profissionais que desenvolveram técnicas de educação e formação voltadas para esse público específico, no sentido de que não somente o anúncio do Evangelho, mas também as relações no âmbito da Igreja e mais especificamente das pastorais, sejam proveitosas.

Quando ainda não havia sido ordenado cardeal, Bergoglio prestou assistência espiritual e religiosa às pessoas doentes em estado terminal e com deficiência, na Federação dos Serviços Sacerdotais de Urgência Noturnos na Argentina, a qual chamava de "Pronto Socorro do Senhor". ${ }^{14}$ Portanto, Bergoglio faz referência às pessoas com deficiência, não só de forma teórica, mas a partir de uma experiência vivida concretamente. Ele conhece de perto as dificuldades, as exclusões, o preconceito que envolvem a vida dessas pessoas, as quais ele se decidiu por ajudar e amparar.

\footnotetext{
${ }^{12}$ Ibid. p. 365

${ }^{13}$ BERGOGLIO, J. M., Caminhando para a maturidade. Reflexões sobre a família e a educação, loc. 149 .

${ }^{14}$ RADIOVATICANO, Serviço Sacerdotal Noturno de Urgência recebe Mensagem do Papa. Disponível em: $\langle$ http://br.radiovaticana.va/news/tags/servi\%C3\%A7o >. Acesso em14 de agosto de 2015.
} 


\subsection{2 \\ O caminhão de lixo como símbolo da cultura do descarte}

A exclusão de Deus no âmbito dos processos educativos ${ }^{15}$ origina a cultura do descarte. Essa exclusão se traduz em violência, desamor e porque não dizer em “eugenia”. O diálogo é banido. Justo o diálogo que é o intercâmbio que destrói preconceitos e que torna possível a interação, "cujo exercício é o meio mais humano de comunicação" ${ }^{16}$ Uma vez que o diálogo é eliminado nos tornamos "filhos da informação e órfãos da comunicação". ${ }^{17}$

Bergoglio observa que se vive em meio a uma realidade cruel, na qual aqueles que sofrem são descartados, "gente que sobra" e que é deixada de lado como um mero "descarte" em verdadeiras caçambas "existenciais". ${ }^{18}$ Diante de situações críticas deste gênero é que o Cardeal Jorge Mario Bergoglio denuncia a "cultura do camião (sic) do lixo: o que não serve deita-se fora". ${ }^{19}$

Escandalizamo-nos quando os meios de comunicação social mostram certas realidades sociais, mas voltamos imediatamente às costas e nada nos move para a consequência política que é chamada a ser a mais alta expressão da caridade. Os mais fracos são descartados: as crianças e os anciãos. ${ }^{20}$

Em casos em que à vida é dado um tratamento inferior à sua qualidade de bem maior, em casos em que a vida se encontra face à possibilidade de extermínio, quando a falta de amor adormece a consciência, quando o preconceito é radical, seguramente estamos frente à "cultura do descartável", que além dos nascituros, das crianças, atinge também homens, mulheres, jovens, idosos, enfermos, pessoas com deficiência, todos os que não são tidos em conta, em razão do egoísmo social.

Antes, em nossa sociedade, podíamos falar de opressores e oprimidos. Com o tempo, notamos que essa categorização não era suficiente, havia que acrescentar mais uma: a de incluídos e excluídos. Hoje em dia, a coisa ficou muito mais

\footnotetext{
15 Referindo-se ao descarte de Deus do âmbito do processo educativo, assim se expressa Bergoglio: "Como entender que em alguns âmbitos educativos se convoquem todos os temas e questões, mas haja único proscrito, um grande marginalizado: Deus?" (Cf. BERGOGLIO, J. M., $O$ Verdadeiro poder é o serviço, p. 76).

${ }^{16}$ Cf. Ibid., 74.

17 Cf. Ibid.

${ }^{18}$ BERGOGLIO, J. M., Escute o clamor do seu povo. São Paulo: Ave-Maria, Edição digital ebookKindle, agosto 2014, loc. 259.

${ }^{19}$ BERGOGLIO, J. M., Só o amor nos salvará. Portugal: Editora Princípia, 2013, p. 81.

${ }^{20}$ Ibid., p. 80.
} 
selvagem e temos que acrescentar outra antinomia: os que entram e os que sobram. Nesta civilização consumista, hedonista, narcisista, estamos nos acostumando ao fato de que certas pessoas são descartáveis. ${ }^{21}$

Em razão dessa realidade em que pessoas são descartáveis, está em curso um tipo de descarte que aponta para uma "cultura de morte". Essa cultura se instala por meio de um genocídio cotidiano, silencioso e protegido: ${ }^{22}$ são os casos em que o aborto não é punível pela lei.

Bergoglio se manifesta contra a eliminação da vida dos nascituros e também se revela contra a não observância dos direitos das crianças que estão por nascer, pois a vida é o primeiro dos direitos humanos e abortar é matar quem não pode se defender. ${ }^{23}$ Além de que, no momento da concepção já se encontra em ato o código genético daquela que é uma pessoa. "Não deixar avançar o

${ }^{21}$ BERGOGLIO, J. M., SKORKA, A., Sobre o céu e a terra. São Paulo: Editora Paralela, 2013, p. 86.

${ }^{22}$ Bergoglio se posiciona contra a "cultura de morte": "Y, desafiando a este Señor, está el grito apagado de tantos niños por nacer: ese genocidio cotidiano, silencioso y protegido; también está allí el reclamo del moribundo abandonado que pide una caricia de ternura que no sabe dar esta cultura de muerte". (Cf. BERGOGLIO J.M., Encuentro de políticos y lesgiladores de América Latina, 03 de agosto de 1999. Disponível em: <http://www.arzbaires.org.ar/inicio/homiliasbergoglio.html>. Acesso em 29 de maio de 2016).

${ }^{23}$ Bergoglio se posiciona contra o aborto não punível por lei: "Comunicado del Card. Bergoglio sobre la resolución para abortos no punibles. El arzobispo de Buenos aires y primado de la Argentina, cardenal Jorge Mario Bergoglio SJ, dio a conocer hoy un mensaje en el marco de la aprobación del protocolo para la actuación de profesionales del subsector estatal de la salud de la ciudad de Buenos Aires ante los casos de abortos no punibles (ANP) previstos en el artículo 86 incisos 1 y 2 del Código Penal. El comunicado dice lo siguiente: Ante la reglamentación del procedimiento sobre los casos de abortos no punibles (ANP) en el ámbito de la Ciudad de Buenos Aires, percibimos una vez mas que se avanza deliberadamente en limitar y eliminar el valor supremo de la vida e ignorar los derechos de los niños por nacer. Al hablar de una madre embarazada hablamos de dos vidas; ambas deben ser preservadas y respetadas pues la vida es de un valor absoluto. "La biología manifiesta de modo contundente a través del ADN, con la secuenciación del genoma humano, que desde el momento de la concepción existe una nueva vida humana que ha de ser tutelada jurídicamente. El derecho a la vida es el derecho humano fundamental." (CEA. "No una vida sino dos". 2011). El aborto nunca es una solución. Debemos escuchar, acompañar y comprender desde nuestro lugar a fin de salvar las dos vidas: respetar al ser humano más pequeño e indefenso, adoptar medidas que pueden preservar su vida, permitir su nacimiento y luego ser creativos en la búsqueda de caminos que lo lleven a su pleno desarrollo. Esta decisión que amplía la despenalización del aborto cediendo a la presión del fallo de la Corte Suprema de la Nación, la cual excediendo sus competencias exhortó a aprobar protocolos, afectando de esta manera la división de poderes y vulnerando el federalismo, tiene consecuencias jurídicas, culturales y éticas porque las leyes configuran la cultura de los pueblos y una legislación que no protege la vida favorece una "cultura de la muerte" (Evangelium vitae, $\mathrm{n}^{\circ} 21$ ).Ante esta lamentable decisión hacemos un llamado a todas las partes involucradas, a los fieles y ciudadanos para que, en un clima de máximo respeto, adoptemos medidas positivas de promoción y protección de la madre y su niño en todos los casos, a favor siempre del derecho a la vida humana".

(Cf. AGENCIA INFORMATIVA CATOLICA ARGENTINA, BERGOGLIO, J. M., Comunicado del Card. Bergoglio sobre la resolución para abortos no punibles, 10 de setembro de 2012. Disponível em: <http://www.aica.org/3161-comunicado-del-card-bergoglio-sobre-la-resolucionpara-abortos-no.html>. Acesso em 08.02.2016). 
desenvolvimento de um ente que já tem todo o código genético de um ser humano não é ético". ${ }^{24}$

\subsection{3 \\ A misericórdia divina}

Na beleza da criação, na oferenda da vida, no serviço e no amor, Bergoglio descobre a infinita ternura e a misericórdia de Deus ${ }^{25}$, em geral esquecida pelos homens. Entretanto, há um recurso humano que vem em auxílio do homem para o que ele se lembre de Deus. Esse recurso é a memória; memória de todas as vezes que o homem chama pelo Senhor e ele ouve; memória de todas as vezes que o homem cai e que o Senhor o levanta; memória de todas as vezes que o homem sofre e o Senhor o conduz ao caminho da alegria; memória da misericórdia de

Deus que é fiel, misericordioso, e que nos espera com paciência e amor.

Dios fiel en el amor, Dios fiel en la promesa. Esta fidelidad, en el texto que acabamos de escuchar, se expresa en términos de misericordia. En sólo 3 versículos repite cuatro veces la palabra y la coloca en medio del conflictivo comportarse humano ante la promesa de Dios. Para demostrar su profundo ser fiel Dios actúa con misericordia, en misericordia. La misericordia de Dios no puede concebirse como un atributo más de su comportamiento para con nosotros sino que constituye el ámbito mismo de su encuentro con cada uno, con todos nosotros, con su pueblo. Es el modo más genuino en que se expresa su fidelidad y la mayor manifestación de su poder (...) para dar lugar al encuentro de amor con su pueblo, con cada uno de sus hijos. (...). No podremos entenderla con la fortaleza de nuestro entendimiento. Sólo se la puede contemplar en la flaqueza de la carne, porque esta fidelidad amorosa precisamente es venida en carne para poder aflorar en misericordia. "No presuman de ustedes mismos" Se nos dice unos versículos más arriba (v. 25). A la misericordia más que entenderla se la encuentra desde nuestra propia nada, nuestras miserias, nuestros pecados. (...) La Biblia nos dice que en la creación Dios nos amasó con sus manos desde el barro de la tierra; en el perdón - en cambio- nos amasa desde el barro de nuestros pecados y lo hace con su corazón fiel al amor que no puede desdecirse porque precisamente tiene hipotecado su corazón en la fidelidad. Se manifiesta más poderoso en redimir que en crear. En su perdón podemos atisbar otro aspecto de su misericordia que no siempre tenemos en cuenta: su paciencia. Como al hijo de la parábola Dios nos espera con paciencia renovadamente cotidiana. ${ }^{26}$

\footnotetext{
${ }^{24}$ BERGOGLIO, J. M.; SKORKA, A., Sobre o céu e a terra, p. 93.

${ }^{25}$ Cf. BERGOGLIO, J. M., O Verdadeiro poder é o serviço, p. 289.

${ }^{26}$ BERGOGLIO, J. M., Homilía en la Misa de Apertura de $94^{a}$ Asamblea Plenaria, 05 de novembro de 2007. Disponível em: <http://www.arzbaires.org.ar/inicio/homiliasbergoglio.html>. Acesso em 23 de maio de 2016.
} 
Bergoglio diz que a misericórdia é um "encontro", no sentido de que ela é um encontro de amor. Aquele que foi tocado nesse encontro sente a necessidade de comunicar essa experiência que só se realiza na fé; um caminho que inclui renúncia, mas que dá frutos, uma verdadeira conversão operada pela misericórdia de um Deus que é bondade e perdão. ${ }^{27}$

Confiante na misericórdia de Deus Bergoglio reconhece as dificuldades a enfrentar. Mas, apesar de tudo, confia que é o hoje do tempo do Reino, pois o tempo do Reino é um tempo de "graça, de bons anúncios, de liberdade e de misericórdia" 28 de inclusão e de fraternidade. O tempo do homem deve estar em sintonia com o tempo de Deus, pois, quando isso não acontece, não se leva em consideração os menos favorecidos.

\subsection{4}

\section{Uma igreja pobre para os pobres}

Nas sessões de trabalho da Congregação dos cardeais que antecederam o Conclave Bergoglio se manifestou em relação as suas expectativas de como deve ser a Igreja: uma Igreja que vá às periferias e que não seja autorreferencial, pois ela não tem luz própria.

Transcrevemos o texto da intervenção do cardeal Bergoglio em uma Congregação Geral antes do Conclave em que foi eleito Sumo Pontífice da Igreja Católica Apostólica Romana:

A doce e confortadora alegria de evangelizar. Fez-se referência à evangelização. É a razão de ser da Igreja. "A doce e confortadora alegria de evangelizar" (Paulo VI). É o próprio Jesus Cristo quem, a partir de dentro, nos impulsiona. 1. Evangelizar supõe zelo apostólico. Evangelizar supõe na Igreja a parresía de sair de si mesma. A Igreja é chamada a sair de si mesma e ir para as periferias, não apenas geográficas, mas também as periferias existenciais: as do mistério do pecado, da

\footnotetext{
${ }^{27}$ A misericórdia divina é um tema fundamental na teologia de Bergoglio. "Si es posible que todo sea nuevo y distinto porque Dios sigue siendo "rico en bondad y misericordia, siempre dispuesto a perdonar" y nos anima a empezar una y otra vez. Hoy nuevamente somos invitados a emprender un camino pascual hacia la Vida, camino que incluye la cruz y la renuncia; que será incómodo pero no estéril. Somos invitados a reconocer que algo no va bien en nosotros mismos, en la sociedad o en la Iglesia, a cambiar, a dar un viraje, a convertirnos". (Cf. BERGOGLIO J.M., Mensaje Cuaresmal del Sr. Arzobispo. A los sacerdotes, consagrados y laicos de la Arquidiócesis, 13 de fevereiro de 2013. Disponível <http://www.arzbaires.org.ar/inicio/homiliasbergoglio.html>. Acesso em 24 de maio de 2016).

${ }^{28}$ BERGOGLIO, J. M., O verdadeiro poder é o serviço, p. 208.
} 
dor, das injustiças, das ignorâncias e recusa religiosa, do pensamento, de toda miséria. 2. Quando a Igreja não sai de si mesma para evangelizar torna-se autorreferencial e então adoece (cf. a mulher encurvada sobre si mesma do Evangelho). Os males que, ao longo do tempo, se dão nas instituições eclesiais têm raiz na autorreferencialidade, uma espécie de narcisismo teológico. No Apocalipse Jesus diz que está à porta e bate. Evidentemente, o texto se refere ao fato de que Jesus bate do lado de fora da porta para entrar... Mas penso nas vezes em que Jesus bate do lado de dentro para que o deixemos sair. A Igreja autorreferencial quer Jesus Cristo dentro de si e não o deixa sair. 3. A Igreja, quando é autorreferencial, sem se dar conta, acredita que tem luz própria; deixa de ser o mysterium lunae e dá lugar a esse mal tão grave que é a mundanidade espiritual (Segundo De Lubac, o pior mal que pode sobrevir à Igreja). Esse viver para dar-se glória uns aos outros. Simplificando: há duas imagens de Igreja: a Igreja evangelizadora que sai de si - a Dei Verbum religiose audiens et fidenter proclamans, ou a Igreja mundana que vive em si, de si e para si. Isto deve dar luz às possíveis mudanças e reformas que tenha que fazer para a salvação das almas. 4. Pensando no próximo Papa: um homem que, a partir da contemplação de Jesus Cristo e da adoração de Jesus Cristo ajude a Igreja a sair de si para as periferias existenciais, que a ajude a ser a mãe fecunda que vive da "doce e confortadora alegria de evangelizar". ${ }^{29}$

Para Bergoglio a Igreja juntamente com outras representações sociais, tem como uma de suas metas, erradicar o preconceito/exclusão, impelindo o homem na direção do irmão marginalizado, sofredor, enfermo, e assim, possibilitando o encontro com os menos favorecidos, com os que estão distantes.

A paróquia nos iguala porque leva ao centro da vida eclesial a todas as periferias: as da pobreza e da marginalidade, as da distância dos grandes centros de vida política, econômica e social, e as periferias existenciais, as do nascimento e da morte, as do pecado e da graça. ${ }^{30}$

Bergoglio pede que os rostos dos sofredores sejam inspiração para que se gere a cultura do encontro, por saber que não há facilidades nesse caminhar que desinstala o homem de sonhos cômodos e o convida a estar disponível para a caridade concreta e para o serviço cotidiano de cuidar da fragilidade dos irmãos mais pobres. ${ }^{31}$ Afinal nos pergunta Bergoglio: "E tu não te comoves com a carne do teu irmão"? ${ }^{32}$

É curioso, a falta de solidariedade é anestésica. Adormece a pessoa em relação às necessidades do outro, ela fica como que trancada em si mesma, anestesiada. Não se afeta, e isso vai se cristalizando, cristalizando, cristalizando, e ela simplesmente

\footnotetext{
${ }^{29}$ INSTITUTO HUMANITAS UNISINOS. "Esta é a intervenção magistral do cardeal Bergoglio no pré-Conclave", 26 de março de 2013. Disponível em: <http://www.ihu.unisinos.br/noticias/518772-esta-e-a-intervencao-magistral-do-cardeal-bergogliono-pre-conclave>. Acesso em 15 de maio de 2016.

${ }^{30}$.BERGOGLIO, J. M., Caminhando para a maturidade, loc. 225.

${ }^{31}$ Ibid., loc. 1641- 1644.

${ }^{32}$ BERGOGLIO, J. M., Só o amor nos salvará, p. 120.
} 
não percebe, não vê; começa por ignorar, começa por se envergonhar de sua própria carne, e vive como se tivesse uma carne angelical, diferente da outra. ${ }^{33}$

Portanto, ele assevera que não devemos nos envergonhar da carne do nosso irmão, mas assumi-la ${ }^{34}$, e nesse assumir, o ser humano se abre à comunicação com o outro e se envereda no caminho da cultura do encontro, abraçando o irmão, sendo solidário em sua alegria ou em sua tristeza. Afinal, somos todos guardas de nossos irmãos.

A Igreja de Bergoglio é a Igreja em saída na direção da carne do irmão, a carne que tem fome e sede, a carne que está doente e ferida, a carne que purga suas faltas na prisão, a carne que não tem o que vestir, a carne que conhece a solidão nascida do menosprezo. É a Igreja do serviço que prepara seus fiéis para o "encontro", em que sua carne sofredora será entregue a vontade de Deus para viver segundo o Espírito. ${ }^{35}$

Seu desejo se coaduna com sua pessoa, pois, o cardeal Jorge Mario Bergoglio é uma pessoa que apesar de reservada, está no meio dos pobres, porque: "O meu povo é pobre e eu sou um deles". ${ }^{36}$ Seu pensamento flui na direção dos oprimidos e excluídos, daqueles que protagonizam as periferias existenciais como um todo.

Essa Igreja sonhada por Bergoglio não está longe de se concretizar, pois, em 2013, o arcebispo Jorge Mario Bergoglio é eleito Papa, e assim, o sonho pode se tornar realidade.

\section{2}

\section{Apresentação e ponderações sobre a pessoa de Francisco}

Antes mesmo de se saber quem seria o novo Papa, Leonardo Boff havia anunciado nas redes sociais que ele se chamaria Francisco. ${ }^{37}$ De fato ele não se

\footnotetext{
${ }^{33}$ Cf. BERGOGliO, J. M., SKORKA, A., FIGUEIROA. M., A solidariedade. São Paulo: Benvirá, 2013, p. 14.

${ }^{34} \mathrm{Cf}$. Ibid.

${ }^{35}$ Cf. BERGOGliO, J. M., Mente aberta, coração que crê. São Paulo: Ave-Maria, 2013, p. 206207.

${ }^{36}$ FRANCISCO, Biografia. Disponível em: $<$ https://w2.vatican.va/content/francesco/pt/biography/documents/papa-francesco-biografiabergoglio.html>. Acesso em 01 de julho de 2016.

37 BOFF, L., O Papa Francisco, chamado a restaurar a Igreja, 14.03.2013. In Brasil de fato. Disponível em: <http://antigo.brasildefato.com.br/node/12324>. Acesso em 17 de junho de 2016.
} 
enganou. Em 13 de março de 2013, quando do anúncio feito com grande alegria, de que tínhamos um Papa, o eminentíssimo e reverendíssimo senhor Jorge Mario, Cardeal da Santa Igreja Romana Bergoglio, o nome por ele escolhido foi Francisco.

Na visão de Boff, Francisco não escolheu um nome e sim um projeto de renovação e reconstrução de uma igreja. Afinal diz Boff, a Igreja está afetadíssima em sua credibilidade em face de problemas financeiros e escândalos morais. Francisco é chamado a restaurá-la. Há aqui uma alusão e uma comparação entre os dois Franciscos: o de Roma e o de Assis. ${ }^{38}$

Boff descreve suas primeiras impressões sobre Francisco como aquele que trará um rosto novo para a Igreja: pobre, humilde, simples, despojada de todo o poder. Um Papa que não vive nos palácios do Vaticano e sim em uma casa de hóspedes; come com todo mundo e se mistura com o povo; um Papa que vem do Terceiro Mundo. Por isso, conhece a pobreza, a injustiça, o grito do oprimido e traz um sentido de abertura para o mundo e para o submundo, o mundo dos sofredores. Para o Brasil Boff sinaliza que Francisco traz um apelo para os jovens para que não se deixem iludir pela cultura do consumismo, para que cuidem do meio ambiente. Enfim, traz uma mensagem de esperança. ${ }^{39}$

De fato, a maneira pela qual Boff descreve Francisco, direciona o nosso olhar a um Papa realmente diferente. Usa paramentos simples; celebra as Missas no ambão como um simples pastor; escolhe morar em Santa Marta; escolhe um carro sem luxo; continua usando sua cruz de Bispo $;{ }^{40}$ dá preferência ao Anel de Pescador de prata e não de ouro, que lhe foi entregue aos 19 dias do mês de março de 2013 no início do seu Pontificado. Essas e outras coisas nos permitem dizer que Francisco é um Papa que surpreende a todos.

Seus gestos e suas palavras tocam o coração daqueles que estão dentro e fora da Igreja. Em vista disso, não é de se admirar que em tão pouco tempo de

\footnotetext{
${ }^{38}$ Cf. Ibid.

${ }^{39}$ BOFF. L., Francisco de Assis e Francisco de Roma. In Mar de ideias e navegação cultural, 18 de novembro de 2014. Disponível em: <https://www.youtube.com/watch?v=w2tfM-5T6z4>. Acesso em 17 de junho de 2016.

${ }^{40}$ RIBEIRO, A.A., A simplicidade do Papa Francisco em 13 gestos. In: Aletéia, 22 de março de 2013. Disponível em: <http://pt.aleteia.org/2013/03/22/a-simplicidade-do-papa-francisco-em-13gestos/>. Acesso em 01 de junho de 2016.
} 
Pontificado haja tantas publicações sobre Francisco, demonstrando assim uma aceitação quase que maciça em relação a ele. Entretanto, há quem o critique.

\subsection{1 \\ O autorretrato}

Francisco foi eleito Papa em sucessão ao Papa Bento XVI. Houve e ainda há grande interesse sobre a pessoa do Papa, principalmente na América Latina, uma vez que Francisco é argentino. Saber sobre Francisco é escutar o que ele mesmo diz sobre si, ${ }^{41}$ observar seus gestos e analisar seu Magistério.

41 "Desde quando tinha 1 ano até quando entrei no seminário, vivi na mesma rua. Era uma rua simples de Buenos Aires, casas baixas. Havia uma pracinha onde jogávamos bola. Me lembro que fugia de casa e ia jogar bola com os meninos depois da escola. Meu pai trabalhava em uma fábrica a 100 metros dali. Era contador. Meus avós viviam a 50 metros. Todos a poucos passos. Me lembro também o nome das pessoas, como padre fui dar os sacramentos, o último conforto a tantos, que me chamavam e eu ia porque gostava deles. Estas são as minhas recordações espontâneas. O senhor jogava bola? Papa Francisco-Sim. Straatniews - Era bom? Papa Francisco - Não. Em Buenos Aires quem jogava como eu era chamado de 'pata dura'. Quer dizer, o mesmo que ter duas pernas esquerdas. Mas eu jogava, era goleiro muitas vezes. Straatniews Como nasceu seu empenho pessoal pelo pobres? Papa Francisco - Sim, tantas recordações me vêm à mente. Me impressionou muito uma senhora que vinha à minha casa três vezes por semana para ajudar minha mãe. Por exemplo, ajudava na lavanderia. Ela tinha dois filhos. Eram italianos, sicilianos, e viveram a guerra, eram muito pobres, mas muito bons. Sempre mantive a recordação daquela mulher. A sua pobreza me impressionava. Nós não éramos ricos, chegávamos ao fim do mês normalmente, mas não além. Não tínhamos um carro, não tirávamos férias ou coisas assim. Mas a ela muitas vezes faltavam as coisas necessárias. Nós tínhamos o suficiente e minha mãe lhe dava as coisas. Depois, ela voltou para a Itália, e voltou de novo para a Argentina. Encontrei-a novamente quando era arcebispo de Buenos Aires, ela tinha 90 anos. E eu a acompanhei até a morte, aos 93 anos. Um dia, ela me deu uma medalha do Sagrado Coração de Jesus que até hoje ainda trago comigo. Esta medalha - que também é uma recordação - me faz muito bem. Queres ver? (Com certa dificuldade, o Papa consegue tirar a medalha, completamente descolorida depois de ser usada por anos). Assim, penso nela todos os dias e o quanto sofreu pela pobreza. E penso a todos os outros que sofreram. Carrego e rezo...(...). Straatniews - Santo Padre, Marc quer convidá-lo para sair e comer uma pizza conosco. O que o senhor acha? Papa Francisco - Eu gostaria, mas não conseguiremos fazer isso. Porque no momento que eu sair daqui as pessoas virão até mim. Quando eu fui mudar as lentes dos meus óculos na cidade, eram 7 da noite. Não havia muitas pessoas na rua. Levaram-me ao ótico e quando sai do carro havia uma mulher que me viu e gritou: "É o Papa". E então eu estava dentro e fora, tanta gente...Straatniews - Faz falta o contato com as pessoas? Papa Francisco - Eu não sinto falta porque as pessoas vêm aqui. Toda quartafeira eu vou à Praça para a Audiência Geral, às vezes eu vou a uma paróquia: estou em contato com as pessoas. Por exemplo, ontem (26 de outubro) vieram mais de 5 mil ciganos à Sala Paulo VI. Straatniews - Pode-se ver que o senhor gosta desta volta na praça durante a Audiência geral ...Papa Francisco - É verdade. Sim, é verdade. Straatniews - O seu homônimo São Francisco escolheu a pobreza radical e vendeu também o seu Evangelho. Como Papa, e Bispo de Roma, o senhor não se sente às vezes sob pressão para vender os tesouros da Igreja? (...) Straatniews - Para muitos, até 13 de março de 2013 o senhor era uma pessoa desconhecida. Em seguida, de um momento para outro, se tornou famoso em todo o mundo. Como viveu essa experiência? Papa Francisco - Chegou e não esperava isso. Eu não perdi a paz. E isso é uma graça de Deus. Eu não penso muito no fato de que sou famoso. Eu digo para mim mesmo: agora eu tenho um lugar importante, mas em dez anos ninguém mais vai me reconhecer (risos). Você sabe, existem dois tipos de fama: a fama dos "grandes" que fizeram grandes coisas, como Madame Curie, e a fama 
Antes de ser eleito Papa, Bergoglio chamou a atenção no pré-Conclave por seu discurso sobre a Igreja, cuja evangelização deve atingir as periferias geográficas e existenciais. Uma vez eleito e entre gritos e vivas, o Papa diz que foram buscá-lo quase no fim do mundo, o que lhe granjeou um de seus apelidos de "Papa do fim do mundo".

Irmãos e irmãs, boa noite! Vós sabeis que o dever do Conclave era dar um Bispo a Roma. Parece que os meus irmãos Cardeais tenham ido buscá-lo quase ao fim do mundo... Eis-me aqui! Agradeço-vos o acolhimento: a comunidade diocesana de Roma tem o seu Bispo. Obrigado! ${ }^{42}$

Em entrevista ao Padre Antonio Spadaro Francisco se dá a conhecer, afirmando que a viagem ao Brasil foi decididamente marcante, pois na Jornada Mundial da Juventude, o Bispo de Roma ${ }^{43}$ se viu frente a uma multidão nas areias de Copacabana. Foi um "mistério" disse Francisco, que não está habituado à multidões. ${ }^{44}$ "Consigo olhar para as pessoas, uma de cada vez, e entrar em

dos vaidosos. Mas essa última fama é como uma bolha de sabão". (Cf. FRANCISCO, Papa fala sobre tesouros da Igreja, pobres e infância, 6 de novembro de 2015. Disponível em: $<$ http://papa.cancaonova.com/papa-fala-sobre-tesouros-da-igreja-pobres-e-infancia/>. Acesso em 03 de julho de 2016).

${ }^{42}$ FRANCISCO, Primeira saudação do Papa Francisco. Benção Apostólica "Urbi et orbi", 13 de março de 2013.2 Disponível em: <http://w2.vatican.va/content/francesco/pt/speeches/2013/march/documents/papa-

francesco_20130313_benedizione-urbi-et-orbi.html>. Acesso em 30.04.2016.

${ }^{43}$ Entrevista concedida ao jornalista Juan Lara: "Santidade, já desde 13 de março que apresenta-se como o Bispo de Roma, com uma insistência muito grande, muito intensa. Por isso nós queríamos entender qual é o sentido profundo dessa insistência: será talvez que trata-se mais de ecumenismo que de colegialidade, trata-se por acaso de ser primus inter pares da Igreja? Obrigado. Papa Francisco: A verdade, nesse ponto, é que não se deve ir além do que diz. O Papa é bispo, Bispo de Roma; e porque é Bispo de Roma é sucessor de Pedro, Vigário de Cristo. São outros títulos, mas o primeiro título é «Bispo de Roma», e daí deriva tudo. Falar, pensar que isso queira dizer ser primus inter pares, não; isso não se segue daquele título. É simplesmente o primeiro título do Papa: Bispo de Roma. Mas temos também os outros... Eu acho que, naquilo que você disse, há algo de ecumenismo: penso que isso possa favorecer um pouco o ecumenismo. Mas, só isso...". (Cf. FRANCISCO, Visita Apostólica ao Brasil por ocasião da XXVIII Jornada Mundial da Juventude. Encontro do Santo Padre com os jornalistas durante o voo de regresso, 28 de julho de 2013. Disponível em:

<https://w2.vatican.va/content/francesco/pt/speeches/2013/july/documents/papa-

francesco_20130728_gmg-conferenza-stampa.html>. Acesso em 03 de julho de 2016).

${ }^{44}$ Em um encontro com os jornalistas nas Filipinas Francisco responde ao jornalista Ignazio Ingrao sobre o medo em relação a sua pessoa, já que o "Vaticano seria inclusivamente alvo dos terroristas islâmicos". Diz ainda o jornalista que "nos sites fundamentalistas apareceu a bandeira do Islão desfraldada sobre São Pedro". Há também os fiéis. Quanto ao terrorismo Francisco revela que responde com mansidão. Mas diz que tem medo de sofrer e que tem um defeito: é um pouco inconsciente. Por isso, quando tem que ficar em meio à multidão, embora tenha receio, enfrenta-o, procurando ficar inconsciente frente ao perigo, pois se tem medo de sofrer, não tem medo de Deus. "O senhor sabe que tenho um defeito: uma boa dose de inconsciência. Sou um inconsciente nestas coisas. Algumas vezes me pus a questão: E se isto acontecesse a mim? E disse ao Senhor: Senhor, peço-Vos apenas uma graça, que não me faça sofrer. É que não sou corajoso em presença da dor; 
contacto de modo pessoal com quem tenho na minha frente. Não estou habituado às massas". 45

Spadaro faz a pergunta que a todos interessa e que o entrevistador fica em dúvida sobre fazê-la ou não: quem é Jorge Mario Bergoglio? Francisco fica em silencio, mas, aceita a pergunta e a responde:

Não sei qual possa ser a definição mais correcta... Eu sou um pecador. Esta é a melhor definição. E não é um modo de dizer, um género literário. Sou um pecador. O Papa continua a reflectir, como se não esperasse aquela pergunta, como se fosse obrigado a uma reflexão ulterior. Sim, posso talvez dizer que sou um pouco astuto, sei mover-me, mas é verdade que sou também um pouco ingénuo. Sim, mas a síntese melhor, aquela que me vem mais de dentro e que sinto mais verdadeira, é exactamente esta. "Sou um pecador para quem o Senhor olhou". E repete: "Sou alguém que é olhado pelo Senhor. A minha divisa, Miserando atque eligendo, senti-a sempre como muito verdadeira para mim (...). Assim sou eu. Assim me sinto. Como Mateus. E aqui o Papa torna-se mais decidido, como se tivesse encontrado a imagem de si próprio de que estava à procura: «É o gesto de Mateus que me toca: agarra-se ao seu dinheiro, como que a dizer: "Não, não eu"! Não, este dinheiro é meu!". Este sou eu: um pecador para o qual o Senhor voltou o seu olhar. E isto é aquilo que disse quando me perguntaram se aceitava a minha eleição para Pontífice. Então sussurra: "Peccator sum, sed super misericordia et infinita patientia Domini nostri Jesu Christi, confusus et in spiritu penitentiae, accepto"». "(Sou pecador, mas confiado na misericórdia e paciência infinita de Nosso Senhor Jesus Cristo, confundido e em espírito de penitência, aceito)." 46

Spadaro continua a entrevista. A pergunta sobre o porquê da escolha em ser jesuíta, ${ }^{47}$ faz Francisco voltar no tempo, quando ainda era jovem, amigo dos

sinto muito, muito medo mas não de Deus. Entretanto, sei que se tomam as medidas de segurança, prudentes mas seguras". (Cf. FRANCISCO, Encontro com os jornalistas durante o voo para Manila, 15 de Janeiro de 2015. Disponível em: <http://w2.vatican.va/content/francesco/pt/speeches/2015/january/documents/papafrancesco_20150115_srilanka-filippine-incontro-giornalisti.html>. Acesso e 03 de julho de 2016). ${ }^{45}$ FRANCISCO, Entrevista ao Papa Francisco. Pe. Antonio Spadaro, 21 de setembro de 2013 Disponível

<http://w2.vatican.va/content/francesco/pt/speeches/2013/september/documents/papa-

francesco_20130921_intervista-spadaro.html>. Acesso em 26 de maio de 2015.

${ }^{46}$ Ibid.

${ }^{47}$ Francisco relata como tomou consciência de que deveria tornar-se sacerdote: "Tive a graça de crescer numa família onde se vivia a fé de forma simples e concreta; mas foi sobretudo a minha avó, mãe do meu pai, que marcou o meu caminho de fé. Era uma mulher que nos explicava, falava de Jesus, ensinava o Catecismo. Lembro-me sempre que, na Sexta-Feira Santa, ela nos levava à noite à procissão de velas; no final desta procissão, passava o «Cristo jacente», e a avó fazia-nos a nós crianças - ajoelhar e dizia-nos: «Olhai! Morreu, mas amanhã ressuscita». Recebi o primeiro anúncio cristão precisamente desta mulher, da minha avó! Tudo isto é muito belo! O primeiro anúncio em casa, com a família. (...) Para mim, porém, há um dia muito importante: 21 de setembro de 1953 (tinha quase 17 anos); celebrava-se o «Dia do Estudante», sendo, para nós, o início da Primavera, ao passo que, para vós, é o início do Outono. Antes de ir para a festa, passei pela paróquia que habitualmente frequentava: encontrei um padre, que não conhecia, e senti necessidade de me confessar. Esta foi para mim uma experiência de encontro: achei que alguém me esperava. Eu não sei o que se passou, não me lembro; não sei sequer por que motivo estivesse 
dominicanos, mas, por escolha Jesuíta, assinalando que viver em comunidade é fundamental.

Da Companhia impressionaram-me três coisas: o espírito missionário, a comunidade e a disciplina. Isto é curioso, porque eu sou um indisciplinado nato, nato, nato. Mas a sua disciplina, o modo de organizar o tempo, impressionaram-me muito. E depois uma coisa para mim verdadeiramente fundamental é a comunidade. (...). Preciso viver a minha vida junto dos outros. ${ }^{48}$

Ao responder a essas duas perguntas Francisco já nos dá pistas não só sobre a sua pessoa, mas também sobre o seu pontificado. Definiu-se como todos nós, como um pecador, ${ }^{49}$ por outro lado o fato de não querer ficar só, já demonstra a sua necessidade de proximidade ${ }^{50}$ com o povo.

lá aquele padre que eu não conhecia, não sei porque senti aquela vontade de me confessar, mas a verdade é que alguém estava à minha espera. Esperava-me há muito tempo. Depois da confissão, senti que qualquer coisa tinha mudado; eu não era o mesmo. Tinha ouvido como que uma voz, uma chamada: fiquei convencido de que devia tornar-me sacerdote. (Cf. FRANCISCO, Vigília de Pentecostes com os movimentos eclesiais, 18 de maio de 2013. Disponível em: $<$ http://w2.vatican.va/content/francesco/pt/speeches/2013/may/documents/papafrancesco_20130518_veglia-pentecoste.html>. Acesso em 01 de julho de 2016).

${ }^{48}$ FRANCISCO, Entrevista ao Papa Francisco. Pe. Antonio Spadaro, 21 de setembro de 2013

${ }^{49} \mathrm{Em}$ entrevista concedida a Aura Miguel ao ser perguntado porque da insistência no pedido de que rezemos por ele, Francisco reafirma que é um pecador, e que tem limitações: "Aura Miguel: Santidade, eu queria lhe perguntar por que motivo pede com tanta insistência para rezarmos pelo senhor. Não é normal, usual, ouvir um Papa pedir assim tanto para rezar por ele...Papa Francisco: Eu sempre pedi isso. Quando era presbítero, pedia isso, mas não com tanta freqüência; comecei a pedi-lo com uma certa freqüência no trabalho de bispo, porque eu sinto que, se não é o Senhor sustentar neste trabalho de ajudar o povo de Deus a avançar, uma pessoa não consegue... Eu me sinto verdadeiramente com muitas limitações, com muitos problemas, sinto-me também pecador vocês sabem disso! - e devo pedir isso. Isso me vem de dentro! Também peço a Nossa Senhora que reze por mim ao Senhor. É um hábito, mas é um hábito que vem-me do coração e também pela necessidade que tenho para o meu trabalho. Eu sinto que devo pedir... Eu não sei, é assim". (Cf. FRANCISCO, Visita Apostólica ao Brasil por ocasião da XXVIII Jornada Mundial da Juventude. Encontro do Santo Padre com os jornalistas durante o voo de regresso, 28 de julho de 2013.Disponível em:

<https://w2.vatican.va/content/francesco/pt/speeches/2013/july/documents/papa-

francesco_20130728_gmg-conferenza-stampa.html>. Acesso em 01 de julho de 2016).

${ }^{50}$ Entrevista com Philip Pullella: "O senhor vive de modo muito austero, ficou em Santa Marta, etc... Vossa Santidade quer que seus colaboradores, mesmo os Cardeais, sigam esse exemplo e vivam, quem sabe, em comunidade, ou é algo apenas para o senhor? Papa Francisco: As mudanças...as mudanças derivam também de duas vertentes: daquilo que nós, cardeais, pedimos, e daquilo que vem da minha personalidade. O senhor falava do fato de eu ter ficado em Santa Marta: mas eu não poderia viver sozinho no Palácio, que não é luxuoso. O apartamento pontifício não é muito luxuoso! É espaçoso, é grande, mas não é luxuoso. Mas eu não posso viver sozinho ou com um pequenino grupo! Preciso de gente, encontrar pessoas, falar com as pessoas... E por isso, quando os alunos das escolas jesuítas me fizeram a pergunta: «Por que faz isso? Por austeridade, por pobreza?», eu respondi: Não, não. É simplesmente por motivos psiquiátricos: psicologicamente eu não posso". (Cf. FRANCISCO, Visita Apostólica ao Brasil por ocasião da XXVIII Jornada Mundial da Juventude. Encontro do Santo Padre com os jornalistas durante o voo de regresso, 28 de julho de 2013). 
O ponto forte da espiritualidade Inaciana que melhor o ajudará será o discernimento, que o auxilia a discernir os sinais dos tempos conforme assevera Spadaro. $^{51}$

O discernimento é, portanto, um pilar da espiritualidade do Papa. Nisto se exprime de modo peculiar a sua identidade jesuítica. (...). E o discernimento realiza-se sempre na presença do Senhor, vendo os sinais, escutando as coisas que acontecem, o sentir das pessoas, especialmente dos pobres. ${ }^{52}$

Ao falar sobre Deus, Francisco diz que O vê como Aquele que sempre antecede ao homem, sendo encontrado no caminho, caminhando, o Deus das surpresas que não fixa nem o tempo, nem o lugar onde acontecerá o "encontro" no qual Ele se faz presente, no tempo e na história de cada qual.

Deus manifesta-Se no tempo e está presente nos processos da História. (...). Deus é sempre uma surpresa e, portanto, não sabes nunca onde e como $\mathrm{O}$ encontras, não és tu a fixar os tempos e os lugares do encontro com Ele. É necessário, portanto, discernir o encontro. Por isso, o discernimento é fundamental (...). Este discernimento requer tempo. Muitos, por exemplo, pensam que as mudanças e as reformas podem acontecer em pouco tempo. Eu creio que será sempre necessário tempo para lançar as bases de uma mudança verdadeira e eficaz. E este é o tempo do discernimento. E por vezes o discernimento, por seu lado, estimula a fazer depressa aquilo que inicialmente se pensava fazer depois. E foi isto o que também me aconteceu nestes meses. (...). As minhas escolhas, mesmo aquelas ligadas à vida quotidiana, como usar um automóvel modesto, estão ligadas a um discernimento espiritual que responde a uma exigência que nasce das coisas, das pessoas, da leitura dos sinais dos tempos. O discernimento no Senhor guia-me no meu modo de governar. ${ }^{53}$

Em Francisco a Igreja é o povo de Deus a caminho na história; uma Igreja que não seja autorreferencial, que saiba abraçar as condições do homem contemporâneo, uma mãe misericordiosa que deve estar sempre próxima ${ }^{54}$, uma Igreja em que o discernimento é crucial e que seja por meio dela que se dê o

\footnotetext{
51 "As ações e decisões devem ter fundamentos profundos e ser acompanhadas de uma leitura atenta, meditativa e orante, dos sinais dos tempos, os quais se encontram por toda a parte: de um grande evento à carta de um fiel comum". Spadaro completa sua reflexão dizendo que Francisco tem experiência do discernimento dos vários espíritos e ainda quando a alma exerce suas faculdades livremente, Francisco espera por uma consolação interior que significa como que uma experiência indicativa do caminho a seguir. (Cf. SPADARO, A., A proposta do Papa Francisco. $O$ futuro rosto da Igreja, p. 17).

${ }^{52}$ FRANCISCO, Entrevista ao Papa Francisco, Pe. Antonio Spadaro,21 de setembro de 2013.

${ }^{53}$ Ibid

${ }^{54}$ Assim Francisco descreve a viagem ao Brasil: "Porque vim visitar gente, quero trata-las como gente. Tocando-a." "Para mim é fundamental a proximidade da Igreja. A Igreja é mãe, e nem você nem eu conhecemos uma mãe por 'correspondência'. A mãe dá carinho, toca, beija, ama. Quando a Igreja, ocupada com mil coisas, se descuida dessa proximidade, se esquece dela e só se comunica com documentos, é como uma mãe que se comunica com seu filho por carta". (Cf. SPADARO, A., A proposta do Papa Francisco. O futuro rosto da Igreja, p. 20).
} 
"encontro" desse homem, em sua noite existencial, em um "caminho" em que a Igreja atue de forma misericordiosa para com os "feridos" que necessitam de compreensão, perdão e amor.

Faz falta uma Igreja que não tenha medo de entrar na noite deles. Precisamos de uma Igreja capaz de encontrá-los no seu caminho. Precisamos de uma Igreja capaz de inserir-se na sua conversa. Precisamos de uma Igreja que saiba dialogar com aqueles discípulos, que, fugindo de Jerusalém, vagam sem meta, sozinhos, com o seu próprio desencanto. (...). Precisamos de uma Igreja capaz de fazer companhia, de ir para além da simples escuta; uma Igreja, que acompanha o caminho pondo-se em viagem com as pessoas; uma Igreja capaz de decifrar a noite contida na fuga de tantos irmãos e irmãs de Jerusalém. (...). Se não formarmos ministros capazes de aquecer o coração das pessoas, de caminhar na noite com elas, de dialogarem com as suas ilusões e desilusões, de recompor as suas desintegrações o que poderemos esperar para o caminho presente e futuro? (...). ${ }^{55}$

Francisco é um homem que precisa estar perto das pessoas; sua visão é a de congregá-las porque, há grande interesse de sua parte em relação ao povo, até certo ponto, maior do que um interesse em debates sobre questões teológicas. Não nasceu para ser monge e por isso escolheu Santa Marta onde não fica só, onde há um expressivo fluxo de pessoas. Em seu dia a dia fica a saudade de comer uma pizza, andar de metro, como costumava fazer em Buenos Aires quando era apenas o padre Bergoglio. Hoje diz que "verdadeiramente gostaria de poder sair; ${ }^{56}$ mas não se pode..., não se pode! Não, não é por precaução; não se pode, porque se tu sais, logo te caem em cima às pessoas... e não se pode. É a realidade!". ${ }^{57}$

55 FRANCISCO, Visita apostólica ao Brasil por ocasião da XXVIII Jornada Mundial da Juventude. Encontro com o Episcopado Brasileiro, 27 de julho de 2013. Disponível em: $<$ https://w2.vatican.va/content/francesco/pt/speeches/2013/july/documents/papafrancesco_20130727_gmg-episcopato-brasile.html>. Acesso em 25 de maio de 2015.

${ }^{56}$ Em entrevista a Hada Messia Francisco diz da sua vontade de caminhar pelas estradas: Salve... O senhor segura-se em pé melhor que eu... Não, não, não! Está bem, está bem. A minha pergunta é: quando o senhor encontrou os jovens argentinos disse a eles, um pouco a brincar e talvez um pouco a sério, que, às vezes, também o senhor sente-se enjaulado; queríamos saber a que se referia exatamente...Papa Francisco: Se você soubesse quantas vezes tive vontade de sair pelas ruas de Roma... É que, em Buenos Aires, eu gostava de caminhar pela estrada, gostava tanto! Nesse sentido, sinto-me um pouco enjaulado. Mas, dizendo isso, devo afirmar também que estes homens da Gendarmeria vaticana são bons, bons, bons, e estou-lhes grato. Agora deixam-me fazer mais qualquer coisa. Eu penso... seu dever é cuidar da segurança. Enjaulado, nesse sentido. Eu gostaria de caminhar pela estrada, mas entendo que não é possível: eu entendo isso. Nesse sentido, eu disse isso. É que o meu hábito era esse; como dizemos nós em Buenos Aires, eu era um padre callejero... (Cf. FRANCISCO, Visita Apostólica ao Brasil por ocasião da XXVIII Jornada Mundial da Juventude. Encontro do Santo Padre com os jornalistas durante o voo de regresso, 28 de julho de 2013). Acesso em 04 de julho de 2016.

${ }^{57}$ FRANCISCO, Encontro com os jornalistas durante o voo de regresso da Coreia a Roma, 18 de agosto de 2014. Disponível em:

<http://w2.vatican.va/content/francesco/pt/speeches/2014/august/documents/papa-

francesco_20140818_corea-conferenza-stampa.html>. Acesso em 30 de maio de 2016. 
Quanto às férias, tira-as em casa, no seu "habitat" e Francisco diz ainda que tem algumas neuroses, como por exemplo, a de ficar em casa, neuroses que trata com mate. ${ }^{58}$

A escolha do nome Francisco se radica em Francisco de Assis assim como previu Leonardo Boff. Francisco mesmo explica como escolheu seu nome:

Alguns não sabiam por que o Bispo de Roma se quis chamar Francisco. Alguns pensaram em Francisco Xavier, em Francisco de Sales, e também em Francisco de Assis. Deixai que vos conte como se passaram as coisas. Na eleição, tinha ao meu lado o Cardeal Cláudio Hummes, o arcebispo emérito de São Paulo e também prefeito emérito da Congregação para o Clero: um grande amigo, um grande amigo! Quando o caso começava a tornar-se um pouco «perigoso», ele animavame. E quando os votos atingiram dois terços, surgiu o habitual aplauso, porque foi eleito o Papa. Ele abraçou-me, beijou-me e disse-me: "Não te esqueças dos pobres"!» E aquela palavra gravou-se-me na cabeça: os pobres, os pobres. Logo depois, associando com os pobres, pensei em Francisco de Assis. Em seguida pensei nas guerras, enquanto continuava o escrutínio até contar todos os votos. E Francisco é o homem da paz. E assim surgiu o nome no meu coração: Francisco de Assis. Para mim, é o homem da pobreza, o homem da paz, o homem que ama e preserva a criação; neste tempo, também a nossa relação com a criação não é muito boa, pois não? [Francisco] é o homem que nos dá este espírito de paz, o homem pobre... Ah, como eu queria uma Igreja pobre e para os pobres! Depois não faltaram algumas brincadeiras....$^{59}$

Francisco diz que não é teólogo ao comentar sobre a Carta Encíclica Lumen

Fidei, escrita a quatro mãos com o Papa Emérito Bento XVI: "volto a esta ideia que talvez não agrade a qualquer teólogo; eu não sou teólogo - penso que o Papa Emérito não seja uma excepção, mas, depois de muitos séculos, este é o primeiro emérito". 60

Em entrevista ao povo filipino Francisco se disse impressionado com as mães que levantavam seus filhos para que ele os visse e comentou sobre a impressão que lhe causou as mães que não escondiam seus filhos com deficiência,

\footnotetext{
${ }^{58} \mathrm{Eu}$ fiz as férias, agora, em casa, como é meu costume fazer. É que uma vez li um livro, interessante, cujo título era: «Alegra-te por seres neurótico». Também eu tenho algumas neuroses, mas é preciso tratá-las bem, as neuroses. Dar-lhes o mate cada dia... Um destas neuroses é que sou um pouco apegado demais ao habitat. A última vez que fiz férias fora de Buenos Aires, com a comunidade jesuíta, foi em 1975. Depois, sempre faço férias - de verdade! - mas no habitat. Mudo o ritmo: durmo mais, leio as coisas que me agradam, ouço a música, rezo mais... E isto repousa-me. (Cf. Ibid.).

${ }^{59}$ FRANCISCO, Encontro com os representantes dos Meios de Comunicação Social, 16 de março de 2013.2 Disponível em: <http://w2.vatican.va/content/francesco/pt/speeches/2013/march/documents/papafrancesco_20130316_rappresentanti-media.html>. Acesso em 24 de abril de 2015.

${ }^{60}$ FRANCISCO, Encontro com os jornalistas durante o voo de regresso da Coreia a Roma, $18 \mathrm{de}$ agosto de 2014.
} 
pois eram seus filhos: "Sim, viam-se tantas crianças deficientes, com deficiência que fazia um pouco de impressão; mas não escondiam a criança, levavam-na ao Papa para que a abençoasse". ${ }^{61}$

\subsection{2}

\section{Socci: um crítico contundente}

Entre seus críticos mais contundentes está o famoso jornalista italiano Antonio Socci. Em seu livro intitulado Non è Francesco. La chiesa nella grande tempesta, Socci não critica diretamente Francisco, mas, critica aquilo que ele aponta como a não observância das regras de votação que regem o Conclave.

Socci afirma que Francisco não é Papa em razão de que, as regras estabelecidas na Constituição apostólica Universi Dominici Gregis não foram observadas e por isso não foram obedecidas. Em razão disso, é nula a eleição de Bergoglio. ${ }^{62}$

Socci toma como base a descrição feita por Elisabetta Piqué ${ }^{63}$ em seu livro Francesco, vita e rivoluzione, no qual há o relato de que houve um dos cardeais que depositou duas cédulas na urna, uma com o nome do seu eleito e outra em branco, que veio presa à primeira cédula, perfazendo um total de 116 cédulas quando eram apenas 115 cardeais a votar. Então, a votação foi anulada e as cédulas foram queimadas.

${ }^{61}$ FRANCISCO, Conferência de imprensa no voo de Manila a Roma, 19 de janeiro de 2015. Disponível em: <http://w2.vatican.va/content/francesco/pt/speeches/2015/january/documents/papafrancesco_20150119_srilanka-filippine-conferenza-stampa.html>. Acesso em 03.072016.

${ }^{62}$ L'elezioni di Bergoglio è nulla. (Cf. SOCCI, A., Non è Francesco. La chiesa nella grande tempesta. Milano: Mondadori, 2014, p. 110).

${ }^{63}$ O livro de Piqué foi traduzido para o português e lançado no Brasil. Eis o texto: "NA CAPELA SISTINA TAMBÉM HÁ SUSPENSE. Na quarta votação, Bergoglio - de rosto sério, mas sereno, resignado - ficou muito perto dos 77 votos. É claro como água que está no caminho de se converter no próximo Papa. E agora, na quinta, está prestes a atingir e ultrapassar largamente o mágico limiar dos 77 votos. Mas acontece o inesperado: logo após a votação, prévio à leitura das cédulas, o cardeal escrutinador, que primeiramente embaralha os papéis depositados na urna, percebe, durante a contagem, que há uma a mais: são 116 e não 115, como deveria ser. De fato, parece que, por engano, um purpurado colocou ali duas cédulas: uma, com o nome do seu escolhido, e a outra, em branco, que ficou colada à que está valendo. Acontece. Nada a ser feito, a votação é anulada de imediato. As cédulas serão incineradas mais tarde sem serem conferidas, e inicia-se então a sexta votação". (Cf. PIQUÉ, E., Papa Francisco: vida e revolução. São Paulo: LeYa, 2014, pp. 32-33). 
Socci alega que a votação não deveria ter sido anulada, pois, a regra do artigo $69^{64}$ da Constituição apostólica Universi Dominici Gregis que regula o Conclave, diz que, se houver duas cédulas com o mesmo nome, vale apenas uma cédula, toma-se dois por um, e se houver duas cédulas com nomes diferentes, nenhuma delas será válida; todavia em nenhum dos casos deve ser anulada a votação. Por outro lado, diz Socci, a mesma Constituição determina que se façam apenas quatro votações ao dia: duas pela manhã e duas à $\operatorname{tarde}^{65}$, mas nesse dia foram feitas mais de quatro votações. A eleição é nula embora não haja culpa de Bergoglio que é eleito na sexta votação. ${ }^{66}$

${ }^{64}$ 69. Os Escrutinadores sentam-se a uma mesa, colocada diante do altar: o primeiro deles toma uma ficha, abre-a, observa o nome do eleito e passa-a ao segundo Escrutinador que, certificando-se por sua vez do nome do eleito, passa-a ao terceiro, o qual a lê, em voz alta e inteligível, de modo que todos os eleitores presentes possam anotar o voto, numa folha apropriada para isso. O próprio Escrutinador, que faz de pregoeiro, anota o nome lido na ficha. Se porventura, no apuramento dos votos, os Escrutinadores encontrarem duas fichas dobradas de maneira tal que pareçam preenchidas por um único eleitor, e se em ambas figura o mesmo nome, elas contam por um único voto; se, pelo contrário, nelas figuram dois nomes diferentes, nenhum dos dois votos será válido; em nenhum dos casos, porém, será anulada a votação. Terminado o apuramento das fichas, os Escrutinadores procedem à soma dos votos obtidos pelos diversos nomes, e anotam-nos numa folha separada. O último dos Escrutinadores, à medida que vai lendo as fichas de voto, fura-as com uma agulha, no ponto onde se encontra a palavra Eligo, e insere-as num fio, a fim de que possam ser mais seguramente conservadas. No fim da leitura dos nomes, as pontas do fio são atadas com um nó, e as fichas assim unidas são colocadas num recipiente, ou a um lado da mesa. (Cf. JOÃO PAULO II, Universi Dominici Gregis, Constituição Apostólica Acerca da Vacância da Sé Apostólica e da Eleição do Romano Pontífice, 22 de fevereiro de 1996. Disponível em:

<http://w2.vatican.va/content/john-paul-ii/pt/apost_constitutions/documents/hf_jpii_apc_22021996_universi-dominici-gregis.html>). Acesso em 10 de julho de 2016.

${ }^{65}$ 63. À eleição, proceder-se-á imediatamente depois de terem sido cumpridos os actos indicados no $\mathrm{n}^{\circ} 54$ da presente Constituição. Se porventura isso se verificar já na tarde do primeiro dia, neste haverá um só escrutínio; nos dias sucessivos, se a eleição não se fizer no primeiro escrutínio, deverá haver duas votações, tanto da parte da manhã como da tarde, dando sempre início às operações de voto na hora já anteriormente estabelecida nas Congregações preparatórias ou durante o período da eleição, mas segundo as modalidades estabelecidas nos $n^{\circ} 64$ e seguintes da presente Constituição.(Cf. Ibid).

${ }^{66}$ Vejamos o que Socci diz: "C'è solo un - per così dire - <<piccolo〉> problema di cui nessuno finora sembra esserci accorto: stando ai fatti riferiti dalla Piqué - e cosi autorevolmente confirmati - l'elezioni di Bergoglio è nulla. Infatti l'articolo 69 della Costituizione apostólica Universi Domini Gregis che regola il Conclave recita testualmente: <<Qualora nello spoglio dei voti gli Scrutatori trovassero due schede piegate in modo da sembrare compilate da un solo elletore, se esse portano lo stesso nome vanno conteggiate per un solo voto, se invece portano due nomi diversi, nessuno dei due voti sarà valido; tuttavia, in nessuno dei due casi viene annullata la votazione. La prima violazione dele norme che si può intravedere è quindi l'aver annulatto una votazione che doveva essere ritenuta valida e scrutinata. Ma come se non bastasse si può ravissare una seconda violazione, perchè si è proceduto con una nuova votazione la quinta di quel giorno (próprio quella che ha eletto Bergoglio) - laddove la stessa Costituizione apostólica prescrive invece che si debbano fare quattro votazioni al giorno, due al mattino e due al pomeriggio (articolo 63).Ne è possibile che il Conclave abbia potuto cambiare <<in corsa >> quelle norme perchè Giovanni Paolo II, in quella Costituizione apostolica, recorda più volte che il Conclave non há assolutamente il potere di modificar le regole. Nemmeno votando all'unanimità. Come già ho precisato, l'invalidità dele procedure seguite al Conclave e delle conseguente elezione non implica 
Francisco tem por hábito responder a telefonemas e cartas e com Socci não foi diferente. Ao receber uma carta aberta de Socci, juntamente com um livro a ele endereçado, chamado La profezia finale. Lettera a Papa Francesco sulla chiesa in tempo di guerra, Francisco vai responder.

A carta é dirigida ao Padre Bergoglio e já de início Socci diz que se dirige a ele como filho da Igreja e não como seu simpatizante. Para além disso, afirma que há uma adulação exagerada em relação à pessoa do $\mathrm{Papa}^{67}$ e passa a expor seu pensamento em relação ao pontificado de Francisco, que lhe responde de próprio punho: "críticas ajudam a caminhar na via reta do Senhor". Agradece a Socci pelo gesto de enviar-lhe o livro e a carta, prometendo rezar ao Senhor e a Virgem por ele e por sua família:

Vaticano 7 febbraio 2016. Sig. Antonio Socci Caro fratello: Ho ricevuto il suo libro e la lettera che lo accompagnava. Grazie tante per questo gesto. Il Signore la ricompensi. Ho cominciato a leggerlo e sono sicuro che tante delle cose riportate mi faranno molto bene. In realtà, anche le critiche ci aiutano a camminare sulla retta via del Signore. La ringrazio davvero tanto per le sue preghiere e quelle della sua famiglia. Le prometto che pregherò per tutti voi chiedendo al Signore di benedirvi e alla Madonna di custodirvi. Suo fratello e servito nel Signore. Francesco. ${ }^{68}$

A resposta de Francisco faz Socci dizer que há coisas nesse Papa que lhe comovem muito, tais como: sua liberdade evangélica e sua simplicidade fora dos esquemas clericais. Diz ainda que reconhece o tom humilde, a atenção e o afeto

nessuna colpa da parte di Bergoglio. E la nullità dell'elezione non rappresenta assolutamente um giudizio di valore sulla persona. Quel pomeriggio del 13 marzo si sono forzati i tempi e si è procedutto con una sesta e decisiva votazione". (Cf. SOCCI, A., Non è Francesco. La chiesa nella grande tempesta, pp. $110-111$ ).

${ }^{67}$ Beatissimo padre, non le dirò che sono uno dei suoi sfegatati estimatori perché mentirei. Però sono um figlio dell Chiesa e ho anch'io il dovere di aiutare il suo ministero anzitutto con la preghiera quotidiana e l'offerta, poi con la critica franca al suo operato quando - in coscienza - mi appare discutibile de è avvolto nell'incenso de un'insopportabile adulazione generale dei media, soprattutto quelli laicisti e nemici di Cristo, che propagano nei suoi confronti un vero culto della personalità. (Cf. SOCCI, A., La profezia finale. Lettera a Papa Francesco sulla Chiesa i tempo di Guerra. Milano: Rizzoli, 2016, p. 91-92).

${ }^{68}$ Francisco escreve a Socci e diz que recebeu o livro e a carta que o acompanhava. Agredeceu ao gesto e diz que pede a Deus que o senhor recompense a Socci. Diz que está certo que as coisas que estão escritas lhe farão bem e também o ajudarão, porque as críticas o ajudam a caminhar na via reta do Senhor. Promete rezar por sua família e lhe encomendar a Nossa Senhora, a ele e a sua família. (Cf. SOCCI, A., In: Lo Straniero. Il blog di Antonio Socci. Disponível em: $<\mathrm{http} / / / \mathrm{www}$.antoniosocci.com/la-lettera-che-mi-ha-scritto-il-papa-su-la-profezia-finale-e-la-miarisposta/>. Acesso em 17 de junho de 2016). 
do Papa em lhe responder a carta e que seu ato serve de exemplo para nós, mas, de toda a forma, a verdade deve ser dita. ${ }^{69}$

\subsection{3 \\ Boff e Kasper: defensores ardorosos}

Entre tantos defensores, Boff e Kasper defendem o pontificado de Francisco de acusações internas e de acusações que desbordam os muros do Vaticano.

No ano de 2015 Boff alertava para uma tentativa de obstaculização do pontificado de Francisco e em carta aberta prestou seu apoio ao Papa. ${ }^{70}$

Há uma campanha mundial e especialmente dentro da Cúria Romana de forte oposição ao Papa Francisco, especialmente ao seu modo carinhoso e informal que caracteriza seu estilo de ser Pastor da Igreja Universal e bispo de Roma. Grupos fortes dentro e fora dos quadros eclesiais que objetivam desestabilizar e até ridicularizar seu modo de ser Papa, despojado dos símbolos de poder, bem no estilo de São Francisco de Assis de quem tomou o nome. No II Congresso de Teologia Continental, realizado em Belo Horizonte entre os dias 26-30 de outubro sob o lema A Igreja que caminha no Espírito a partir dos pobres resolveu escrever esta carta aberta em apoio ao Papa Francisco. Logo aderiram cerca de 300 pessoas do Brasil, de toda América Latina, do Caribe e de representantes da Europa, do Canadá e dos Estados Unidos. Pedimos divulgarem esta carta e testemunharem a sua adesão para o e-mail <valecarusi@gmail com.> da embaixada argentina junto à Santa Sé. Lboff .

Assim como Boff, Kasper também sai em defesa de Francisco e diz que vozes se levantam contra o Papa dentro e fora da Igreja. Assevera que fizeram do Papa uma espécie de estrela ou então de um Papa com pouco peso teológico. Em verdade diz Kasper, Francisco não é nem uma coisa nem outra e sim aquele que se deixa surpreender por Deus, rompendo os esquemas habituais, e a isso se opõem resistências. Portanto diz Kasper, Francisco em seu pontificado se radica na

\footnotetext{
${ }^{69}$ Assim se pronuncia Socci: "Ci sono cose di questo Papa che mi commuovono profondamente (l'ho scritto nel libro). Mi entusiasma la sua libertà evangelica, la sua semplicità, il suo essere fuori dagli schemi clericali. (...) Le parole che Francesco mi ha scritto (...) sono anzitutto, per ciascuno di noi, un esempio di umiltà e di paternità. (...) Ma infine un pontificato è anzitutto il suo magistero e il suo governo della Chiesa e di fronte allo smarrimento e alla confusione che in questi tre anni hanno investito il popolo cristiano ho dovuto e voluto dire la verità, a costo del suicidio professionale e morale". (Cf. Ibid).

70 Cf. BOFF, L., Carta de apoio ao Papa Francisco, 07 de novembro de 2015. In leonardoBOFF.com. Disponível em: <https://leonardoboff.wordpress.com/2015/11/07/carta-deapoio-ao-papa-francisco/>. Acesso em 20 de junho de 2016.
} 
novidade evangélica que é sempre nova e perenemente atual de forma a permitir uma nova orientação e um chamado à conversão. ${ }^{71}$

O Bispo de Roma, como prefere ser chamado, não é um teórico - parte de fatos. De acordo com o cardeal Walter Kasper, pode se dizer que Francisco por si só é um fato, no sentido de que se mostra presente, próximo e se impõe em razão de forte carisma, pois ao se comunicar pede a participação ativa de quem o escuta. $^{72}$ Por outro lado afirma Kasper, Francisco pode não ser um teólogo no sentido acadêmico do termo, mas, é assaz criativo e original, sendo o porta voz de uma Teologia do Povo, cuja ideia fundamental é a de um Deus que cria o mundo para que se viva em harmonia uns com os outros. ${ }^{73}$

\footnotetext{
${ }^{71}$ Kasper diz que não é de se estranhar que em apenas um ano e meio de ministério já se tenha um número considerável de publicações a respeito de Papa Francisco. A maior parte das publicações tem lugar em razão Da acolhida que Francisco encontrou no povo de Deus e em muitos outros. Não faltam críticas na mídia e na web e também em alguns ambientes da Igreja. Alguns o acham com pouco embasamento teológico e outros o vêem como um superstar, mas não é uma coisa nem outroa. A surpreendente novida que de Francisco não consiste em inovações, mas na eterna novidade do Evangelho que é sempre o mesmo, mas sempre novo e atual. A memória do Evangelho e sua eterna novidade é certamente sempre e também perigosa. Isso chama a conversão e a uma nova orientação. Deve-se continuar a se deixar surpreender por Deus e romper sempre e de novo os esquemas habituais. Isso promove resistências. "Non meraviglia che, già dopo um anno e mezzo dall'inizio del suo ministero, sai apparsa uma mole imprevedibile di pubblicazioni su papa Francesco. La maggior parte delle pubblicazioni rispondono all'alto gradimento che il papa, già dopo pochi giorni e poche settimane, há incontrato nella stagrande maggioranza del popolo di Dio e molte oltre. Non mancano certamente voce critiche, che dicono: questo papa non piace perché piace troppo. Nel frattempo sono aumentate le riserve, la critica aperta o anche celata in alcuni media e siti web, e pure in alcuni ambienti della chiesa. (...). Se gli uni fanno del papa uma specie di star, gli altri lo considerano di scarso peso teológico. Papa Francesco non è né l'uma né l'altra cosa. Che cosa, dunque? (...). La sorprendente novità della sorpresa rappresentata da questo papa non consiste in alcune innovazioni, bensi nell'eterna novità del Vangelo, che è sempre lo stesso e tuttavia di continuo sorprendentemente nuovo e perennemente attuale. (...) La memoria del vangelo e della sua eterna novitá è certamente sempre anche uma memoria pericolosa. Esso mette in questione e chiama alla conversione e ad um nuovo orientamento. Ci si deve di continuo lasciar sorprendere da Dio e rompere sempre di nuovo con gli schemi abituali. Ciò suscita resistenza".( Cf. KASPER, W., Papa Francesco. La rivoluzione della tenerezza e dell'amore. Brescia: Queriniana, 2015, pp. 14 -17).

${ }^{72}$ Assim se refere Kasper em relação a Francisco: "Le parole sono parole, se ne possono dire tante, ma è la persona in sé stessa che deve convincere. E qui si impone il forte carisma di Francesco, che nelle sue iniziative di comunicazione sempre richiede la partecipazione ativa di chi l'ascolta. (Cf. KASPER, Testimone della misericordia. Il mio viaggio com Francesco p. 56). Mais adiante Kasper diz que: Francesco è il papa del dialogo". (Cf. KASPER, W., Testimone della misericordia. Il mio viaggio com Francesco. Milano, Garzanti, 2015, p. 107).

${ }^{73}$ Assim se expressa Kasper ao falar de Francisco: "Dietro ogni sua parola c'è uma teologia sapienziale molto densa, quella teologia del popolo tipicamente argentina, ma le cui prime radici troviamo nella teologia europea, che Bergoglio conosce molto bene (...) che Dio ha creato il mondo di armonia dove ognuno ha il suo spazio e il diritto di vivere in pace con gli altri. Queste sono le idee fondamentali della teologia del popolo". (Cf. Ibid. pp. 67-69).
} 
Enfim, as impressões sobre a pessoa do Papa vão se formando ao longo do seu Pontificado que, sendo considerado um pontificado de mudanças, certamente encontra resistência e defensores, com bem salientou o cardeal Kasper.

\section{3}

\section{Alguns pontos fundamentais da teologia de Francisco}

O desejo de Bergoglio é o de uma Igreja pobre para os pobres. A igreja que vai para as ruas para evangelizar, para buscar, para bater às portas, com palavras de esperança, em atitude que vise à integração de todos na sociedade. Essa é a proposta que Francisco quer realizar: a Igreja que sai às periferias, que derruba muralhas e que constrói pontes, que agrega migrantes, que carece de conversão, que não deve ser fechada em si mesma, não devendo ser autorreferencial.

Os desafios de hoje para o mundo e para a Igreja são transmitidos por Francisco através de mensagens constituídas de palavras simples e cotidianas, que buscam alcançar o homem dialogal, esse homem que na qualidade de ser de relação precisa viver em comunidade.

O dia a dia vem retratado em suas homilias, discursos e mensagens, a partir de sua observação diária em relação às atitudes humanas - ostensivas, cotidianas, globais, muitas vezes perversas - as quais são intituladas como "culturas" que fazem parte do dia a dia da humanidade sendo por ela assimiladas.

Assim, os ditos de matriz "bergogliana" continuam a fazer parte de sua forma de comunicação: a cultura do caminhão de lixo, a cultura do egoísmo, a cultura do individualismo, a cultura da indiferença, em que a exclusão social se faz presente, a cultura do descartável que pensa o ser humano como objeto que se usa e se joga fora ${ }^{74}$, a cultura do provisório, a cultura do conflito, a cultura do preconceito, que descarta e abandona velhos, pobres, enfermos, crianças, pessoas com deficiência, a cultura midiática ${ }^{75}$, que no mais das vezes entende a Igreja como algo ultrapassado, fora do mundo, contra o mundo, cuja mensagem não revela amor e sim escravidão, ou é o tipo de mensagem a qual não se deve dar crédito, uma mensagem na qual não se confia, a cultura do efêmero, a excludente

\footnotetext{
${ }^{74}$ Cf. EG 53.

${ }^{75}$ EG 79.
} 
e egoísta cultura do bem-estar, ${ }^{76}$ a cultura do desencontro, a cultura do desperdício, a cultura da globalização, enfim, expressões fortes que apontam para a sua visão em relação ao mundo atual e que podemos resumir como a "cultura do descarte".

A essas culturas enraizadas no mundo moderno, que tendem a levar o homem em direção ao vazio existencial, pois que calcadas em ídolos que devem ser erradicados, se contrapõe a "cultura do encontro", visto que esse encontro rejeita toda a globalização e universalização do afastamento, tão diversa da discriminação e da intolerância.

Francisco em sua linguagem muito particular clama a todos para que promovam a "cultura do encontro" em contraposição à "cultura do descarte". Esse encontro acontece no "caminho", no caminhar, em uma travessia esculpida e construída por meio de pontes humanas "misericordiosas" e de proximidade, de tal forma que a "cultura do encontro" se transforme em uma cultura inserida no dia a dia.

Esse desejo tem raízes na verdade, pois, a verdade é um encontro, um "encontro" entre pessoas humanas e um "encontro" com a Pessoa Divina. Por isso Francisco convoca a todos, tanto políticos como religiosos, que se solidarizem de modo fraterno, despindo-se do egoísmo e do isolamento rumo a "cultura do encontro", que vem a ser a tônica seu pensamento em prol da promoção integral da humanidade.

Os pobres são aqueles a quem Francisco destina grande parte de suas mensagens eclesiais no sentido de alertar ao mundo sobre a exclusão a que estão submetidos, dando voz a quem não pode se defender, pois eles são a grande riqueza da Igreja.

\footnotetext{
${ }^{76}$ A cultura do bem-estar, que nos leva a pensar em nós mesmos, torna-nos insensíveis aos gritos dos outros, faz-nos viver como se fôssemos bolas de sabão: estas são bonitas mas não são nada, são pura ilusão do fútil, do provisório. Esta cultura do bem-estar leva à indiferença a respeito dos outros; antes, leva à globalização da indiferença. Neste mundo da globalização, caímos na globalização da indiferença. Habituamo-nos ao sofrimento do outro, não nos diz respeito, não nos interessa, não é responsabilidade nossa! (Cf. FRANCISCO, Santa Missa pelas vítimas dos naufrágios. Viagem a Lampedusa, 08 de julho de 2013. Disponível em: $<$ https://w2.vatican.va/content/francesco/pt/homilies/2013/documents/papafrancesco_20130708_omelia-lampedusa.html>. Acesso em 28 de maio de 2015).
} 
Incansável quando se trata de defendê-los, elenca um grande leque daqueles que muitas vezes vivem em situação indigna, a exemplo dos pobres, dos idosos, das crianças, dos refugiados, dos migrantes e daqueles cujos direitos não são respeitados, como os direitos dos nascituros. São vítimas da "cultura do descarte" e da indiferença quase que globalizada.

Assim sendo, passamos a apreciar aquilo que julgamos ser fundamental dentre os pontos que se destacam na doutrina teológico pastoral de Francisco, com o olhar voltado para as pessoas com deficiência.

\subsection{1 \\ A opção preferencial pelos pobres}

A Exortação Apostólica Evangelii Gaudium aponta para os pobres como aqueles que têm um lugar preferencial no coração de Deus ${ }^{77}$ e o mesmo se pode dizer em relação ao coração de Francisco. ${ }^{78}$ Tanto é assim que seu desejo é o de uma Igreja pobre para os pobres. ${ }^{79}$

\footnotetext{
${ }^{77}$ EG 197.

${ }^{78}$ Apesar dessa profunda identificação com os pobres Francisco nos diz que ama a todos, tanto ricos quanto pobres, mas tem o dever de lembrar aos ricos que eles devem ajudar aos pobres, respeitá-los e promove-los por meio de uma solidariedade desinteressada. (Cf. EG 58).

${ }^{79}$ Walter Kasper assim se expressa sobre Francisco em relação aos pobres: "Os Movimentos Populares se reuniram a convite de Francisco em uma emblemática constatação do que significa a cultura do encontro e do que pretende o pontificado de Francisco que preza a igreja pobre para os pobres- os cartoneros sul americanos, os sans papiers, os sem-terra do Brasil, entre outros, estiveram presentes. Francisco declarou que apoia a luta desses irmãos menos favorecidos e no mais das vezes excluídos. Para Kasper esse encontro demonstra de forma cabal as raízes de Francisco e a sua ideia e sua luta em prol do que é ser igreja nas periferias. Kasper sai em defesa de Francisco ao dizer que não se trata de uma nova doutrina, mas da mesma doutrina atualizada. Francisco não quer apenas falar dos pobres, mas mostrá-los ao mundo para que as nações tomem providências no sentido de estancar a pobreza. O Cardeal afirma que "o papa que veio dos confins da terra conhece bem a pobreza e a miséria de dois terços da humanidade, sobretudo no hemisfério sul". E, portanto, seu pedido de justa distribuição de renda além de estar de acordo com a Doutrina Social da Igreja é pertinente. (Cf. KASPER, W., Testimone dela misericórdia. Il mio viaggio com Francesco, 2015, p. 77-80). Em Papa Francesco La rivoluzine della tenerezza e dell'amore Kasper aponta para uma economia falsa e enganosa que destrói os seres humanos e diz que essa é exatamente isso que Francisco que mostrar ao mundo - uma economia destrutiva que resulta em destruição. $O$ problema dos pobres e da pobreza é o ponto chave a ser enfrentado. O escândalo que grita aos céus, a pobreza e miséria do hemisfério sul de onde vem Francisco, que quer mostrar os fundamentos de uma economia errada. A pobreza de massa não é um destino natural, mas resultado de uma falsa economia que vê o ser humano de maneira individual ao ponto de destruir as relações sociais e principalmente as relações familiares. Eis o texto: “(...) al problema dei poveri e della povertà (...) per papa Francesco è questo oggi uno dei molti problemi, se no il problema chiave, da affrontare. Sullo sfondo sta per papa Francesco lo scandalo, che grida al cielo, della povertà e della miseria specialmente nell'emisfero sud, da cui egli stesso proviene e i cui conflitti há conosciuto per esperienza personale. (...) Il papa (...) vuole mettere allo scoperto attegiamente fondamentali sbagliati, che portano ad'un economia sbagliata. Per lui l'economia è um evento
} 
Esse interesse em relação aos pobres vem expresso logo no início da Evangelii Gaudium, quando Francisco diz que "quando a vida interior se fecha aos próprios interesses”, deixa de haver espaço para os outros, já não entram os pobres, não se ouve a voz de Deus. ${ }^{80}$

Sua preocupação se faz sentir quando sustenta que as nações mais pobres e também os pobres são acusados pela violência. Isso ocorre em razão da desigualdade social, uma situação que persistindo no tempo, inviabiliza a igualdade de oportunidades para aqueles mais carentes, e que, por falta de condições melhores de vida, tendem à agressão. ${ }^{81}$ Por isso, "cada cristão e cada comunidade são chamados a ser instrumentos de Deus a serviço da libertação e da promoção dos pobres, para que possam integrar-se plenamente na sociedade" ${ }^{82}$

Francisco atesta que "a pobreza, para nós cristãos, não é uma categoria sociológica, filosófica ou cultural. Não! É uma categoria teologal", ${ }^{83}$ sendo este o cerne da proposta pastoral para sua Igreja, que faz a opção pelos pobres.

A opção pelos pobres requer de todos os fiéis, atitudes concretas, uma "atenção amiga" ${ }^{84}$ pelo outro, testemunhos visíveis que saiam do plano das ideias e se concretizem em procedimentos palpáveis acompanhando constante e

comunicativo costituito dallo scambio di merci tra gli esseri umani. La povertà di massa, perciò non è semplicemente un destino naturale, ma il risultato di un'economia falsa, che considera e sfrutta l'essere umano solo come individuo e con tale individualismo distrugge i legami social, specialmente i legami familiar" (EG 67). (Cf. KASPER, W., Papa Francesco. La rivoluzione della tenerezza e dell'amore, 2015, p. 105 -107).

${ }^{80} \mathrm{EG} 1$.

${ }^{81}$ Cf. EG 59.

${ }^{82}$ EG 187.

83 FRANCISCO, Vigília de pentecoste com os movimentos eclesiais, 18 de maio de 2013. Disponível em <http://w2.vatican.va/content/francesco/pt/speeches/2013/may/documents/papafrancesco_20130518_veglia-pentecoste.html>. Acesso em 11 de junho de 2015

${ }^{84} \mathrm{O}$ nosso compromisso (...) não é um excesso de activismo, mas primariamente uma atenção prestada ao outro. (...). Esta atenção amiga é o início duma verdadeira preocupação pela sua pessoa e, a partir dela, desejo procurar efectivamente o seu bem. Isto implica apreciar o pobre na sua bondade própria, com o seu modo de ser, com a sua cultura, com a sua forma de viver a fé. O amor autêntico é sempre contemplativo, permitindo-nos servir o outro não por necessidade ou vaidade, mas porque ele é belo, independentemente da sua aparência: "Do amor, pelo qual uma pessoa é agradável a outra, depende que lhe dê algo de graça». Quando amado, o pobre «é estimado como de alto valor», e isto diferencia a autêntica opção pelos pobres de qualquer ideologia, de qualquer tentativa de utilizar os pobres ao serviço de interesses pessoais ou políticos. Unicamente a partir desta proximidade real e cordial é que podemos acompanhá-los adequadamente no seu caminho de libertação. Só isto tornará possível que « os pobres se sintam, em cada comunidade cristã, como "em casa". Não seria, este estilo, a maior e mais eficaz apresentação da boa nova do Reino?" Sem a opção preferencial pelos pobres, "o anúncio do Evangelho - e este anúncio é a primeira caridade - corre o risco de não ser compreendido ou de afogar-se naquele mar de palavras que a atual sociedade da comunicação diariamente nos apresenta". (Cf. EG 199). 
misericordiosamente aqueles que sofrem. ${ }^{85} \mathrm{E}$ que ninguém venha dizer, desculpando-se e justificando-se, que suas tarefas pessoais o impedem de se debruçar sobre a questão dos pobres. ${ }^{86}$

A opção preferencial pelos pobres deve realizar-se principalmente em uma solicitude religiosa privilegiada e prioritária, pois, de acordo com Francisco, a pior discriminação que sofrem os pobres é a falta de cuidado espiritual ${ }^{87}$, observando que essa falta de cuidado se dá no âmbito das pastorais. ${ }^{88}$

Por isso Francisco pede que o anúncio do Evangelho tenha duas metas: que o anúncio seja feito em lugares mais necessitados ${ }^{89}$ e que haja uma constante saída em direção às periferias existenciais e geográficas, no sentido de que todos sejam iluminados pela luz do Evangelho. ${ }^{90}$

\subsection{2}

\section{A dignidade humana}

Cada pessoa humana é única, irrepetível e dotada de uma dignidade cuja primazia deve ser reconhecida pela comunidade internacional, fazendo valer o primado do princípio pro homine - que prioriza a dignidade da pessoa humana

\footnotetext{
${ }^{85}$ Em Laudato Si Francisco fica claro que um dos eixos que atravessam toda a Encíclica, diz respeito à relação íntima que há entre os pobres e as atividades do planeta LS 16. Francisco elenca o drama dos pobres que são afligidos pelo descaso em relação ao meio ambiente: são vítimas da poluição atmosférica (n.20), muitos vivem em lugares afetados pelo aquecimento (n. 25). São vítimas da emigração forçada em razão do aquecimento (n. 25), um problema que ainda não foi resolvido (n. 28), há a poluição das águas que os afeta; não tem água potável (n.30); os efeitos mais graves de todas as agressões ambientais recaem sobre as pessoas mais pobres (. 48); a comida que se desperdiça é como se fosse roubada da mesa do pobre (n. 50) e também EG 53; há desinteresse pelos pobres e pelo tráfico de pessoas (n. 91), necessidade de programas sociais para ajudar aos mais pobres (n. 109); dificuldade de os pobres terem casa própria (n.152). Walter Kasper assinala que o documento certamente terá um forte peso entre as nações em razão de sua mensagem que engloba os pobres. Vejamos o que ele diz: "Possiamo dire che la Laudato Si sia la prima encíclica creaturale, dove la risposta al doppio grido intrecciato dele creature e dei poveri fa di questo documento un grande testo che avrà certamente importante effetti come li ebbe a suo tempo l'enciclica Pacem in Terris". (Cf. KASPER, W., Testimone della misericordia. Il mio viaggio con Francesco, 2015, p. 25).

${ }^{86}$ Cf. EG 201.

${ }^{87}$ Cf. EG 200.

${ }^{88} \mathrm{Cf}$. EG 70.

${ }^{89} \mathrm{Cf}$. EG 30.

${ }^{90}$ Cf. EG 20.
} 
acima de tudo. ${ }^{91}$ Por isso Francisco faz um pedido: A cada pessoa deste mundo, peço que não esqueça esta sua dignidade que ninguém tem o direito de lhe tirar. ${ }^{92}$

Por isso, o promover e o ratificar a dignidade da pessoa humana faz com que seus inalienáveis direitos e deveres sejam reconhecidos e resguardados, direitos esses que não estão ao sabor do arbítrio de quem quer que seja. "Afirmar a dignidade da pessoa significa reconhecer a preciosidade da vida humana, que nos é dada gratuitamente não podendo, por conseguinte, ser objeto de troca ou de comércio": 93 Por isso, "a pessoa humana não se deveria vender e comprar como uma mercadoria. Quem usa e explora mesmo indirectamente, torna-se cúmplice desta prepotência". ${ }^{94}$

Acentuando e enfatizando a primazia da dignidade da pessoa humana Francisco assevera que: "É preciso pôr a dignidade da pessoa humana no âmago de cada perspectiva e de cada gesto. Os outros interesses, embora sejam legítimos, são secundários. No centro está a dignidade da pessoa humana!"95 A origem dessa dignidade se reporta a criação do homem como imagem de Deus; todos nós somos imagens de Deus! A preocupação de Francisco se faz notar conforme atestado em Laudato Si: "O fato de insistir na afirmação de que o ser humano é imagem de Deus não deveria fazer-nos esquecer de que cada criatura tem uma função e nenhuma é supérflua", ${ }^{96}$ pois, diz ele, o ser humano como criatura deste mundo merece ser feliz e pelo fato de ser portador de uma dignidade especial, é

${ }^{91}$ FRANCISCO, A delegação da associação internacional de direito penal, 23 de outubro de $2014 . \quad$ Disponível em: <http://w2.vatican.va/content/francesco/pt/speeches/2014/october/documents/papa-

francesco_20141023_associazione-internazionale-diritto-penale.html>. Acesso em 20 de abril de 2015.

92 LS 205.

93 FRANCISCO, Visita ao Parlamento Europeu, 25 de novembro de 2014. Disponível em: $<$ https://w2.vatican.va/content/francesco/pt/speeches/2014/november/documents/papafrancesco_20141125_strasburgo-parlamento-europeo.html >. Acesso em 14 de junho de 2015.

94 FRANCISCO, Discurso aos novos embaixadores junto da Santa Sé por ocasião da apresentação das cartas credenciais, 12 de dezembro de 2013. Disponível em: <http://w2.vatican.va/content/francesco/pt/speeches/2013/december/documents/papafrancesco_20131212_credenziali-nuovi-ambasciatori.html>. Acesso em 22 de julho de 2015

${ }^{95}$ FRANCISCO, Visita pastoral à região de Molise, Italia, 05 de julho de 2014. Disponível em: $<$ https://w2.vatican.va/content/francesco/pt/homilies/2014/documents/papafrancesco_20140705_molise-omelia.pdf>. Acesso em 02 de maio de 2015.

${ }^{96}$ Cf. LS 84 . 
absolutamente descabido o descarte que vem sofrendo e que se acentua face à degradação ambiental. ${ }^{97}$

Essa dignidade especial vem a demonstrar que os seres humanos não são coisas, pois, são criados à imagem e semelhança de Deus e sua vida caótica contrasta com aquilo que lhe é de direito, ou seja: uma vida digna; muitas vezes vivem uma vida reduzida à escravidão, de onde não brota expectativa de vida mais dignificante..$^{98}$

Uma sociedade que seja deveras humana deve priorizar e por no centro a pessoa humana e sua dignidade, mantendo o olhar firme na solidariedade e na fraternidade, e a partir desse duplo binômio, edificar os pilares sobre os quais se radica o valor de cada pessoa, eliminando as divisões e descartando as exclusões.

Somado a isso é preciso dizer que é de cunho eclesial a defesa da dignidade da pessoa humana em todas as fases da vida, que começa na concepção. ${ }^{99}$ Portanto, o aborto é inaceitável. Nesse sentido se pronunciou contra o aborto, não punível, quando cardeal em Buenos Aires. O aborto não punível é aquele que por lei é descriminalizado, como o caso brasileiro dos anencéfalos.

Uma grave violação e afronta aos direitos humanos constituindo-se em uma ofensa a dignidade das pessoas tem lugar, por exemplo, no tráfico de seres humanos, "que atinge as pessoas mais vulneráveis da sociedade: as mulheres e as jovens, os meninos e as meninas, os deficientes, os mais pobres". ${ }^{100}$

\footnotetext{
${ }^{97}$ Cf. LS 43.

${ }^{98} \mathrm{Cf}$. LS 154

99 “O primeiro direito de uma pessoa humana é a sua vida. Ela possui outros bens, e alguns deles são mais preciosos; mas este é o bem fundamental, condição para todos os outros". (Congregação para a Doutrina da Fé, Declaração sobre o aborto provocado, 18 de Novembro de 1974, 11). As coisas têm um preço e podem ser vendidas, mas as pessoas têm uma dignidade, valem mais do que as coisas e não têm preço. Encontramo-nos muitas vezes em situações onde vemos que aquilo que menos custa é a vida. Por isso, a atenção à vida humana na sua totalidade tornou-se nos últimos tempos uma verdadeira prioridade do Magistério da Igreja, de maneira particular àquela mais inerme, ou seja, ao portador de deficiência, ao enfermo, ao nascituro, à criança e ao idoso, à vida mais indefesa. (...) Sede testemunhas e promotores desta "cultura da vida". O fato de serdes católicos comporta uma maior responsabilidade: em primeiro lugar, em relação a vós mesmos, pelo compromisso de coerência com a vocação cristã; e depois em relação à cultura contemporânea, a fim de contribuir para reconhecer na vida humana a dimensão transcendente, o sinal da obra criadora de Deus, desde o primeiro instante da sua concepção. (Cf. FRANCISCO, Discurso aos ginecologistas católicos participantes de uma conferência mundial organizada pela Federação Internacional das Associações Católica, 20 de setembro de 2013. Disponível em: $<$ http://w2.vatican.va/content/francesco/pt/speeches/2013/september/documents/papafrancesco_20130920_associazioni-medici-cattolici.html>. Acesso em 03 de fevereiro de 2016). 100 FRANCISCO, Discurso aos novos embaixadores junto da Santa Sé por ocasião da apresentação das cartas credenciais, 12 de dezembro de 2013. Disponível em:
} 
De toda forma é sabido que a todos deve ser dada a possibilidade de viver de acordo com a sua dignidade e esse é o apelo que se faz sentir para que o meio ambiente se torne essa "casa universal" capaz de assegurar que cada qual viva em harmonia consigo mesmo, com os pares, e com toda a criação.

Esse descarte e todas as formas de exclusão são fruto de uma sociedade que tem como parâmetros o homem funcional, eficiente e descartável. Mas, apesar dos percalços, o Bispo de Roma diz que não descansará enquanto houver seres humanos ofendidos em sua dignidade. ${ }^{101}$

Entre estes seres frágeis, de que a Igreja quer cuidar com predileção, estão também os nascituros, os mais inermes e inocentes de todos, a quem hoje se quer negar a dignidade humana para poder fazer deles o que apetece, tirando-lhes a vida e promovendo legislações para que ninguém o possa impedir. ${ }^{102}$

Ninguém pode nos tirar essa dignidade posto que, quem a nós a confere é o próprio Deus, cujo amor é infinito e inabalável. ${ }^{103}$ Deus fez o homem com suas mãos, e nós somos sua imagem e semelhança. Portanto, a dignidade humana se radica em Deus estando sempre acima e superior a qualquer lei humana, e por isso, inegociável.

\subsection{3}

\section{A "cultura do descarte"}

Desde o início de seu pontificado Francisco vem destacando o quão importante é superar a "cultura do descarte" e, dentre o elenco dos descartados, aponta para aqueles que estão à margem da sociedade e são alijados do contexto das cidades, em razão da indiferença de seus pares.

A pessoa humana é um ser de relação que se realiza na dimensão das relações interpessoais, no contexto da justiça e da caridade, devendo ter

<https://w2.vatican.va/content/francesco/pt/speeches/2013/december/documents/papafrancesco_20131212_credenziali-nuovi-ambasciatori.html>. Acesso em 03 de maio de 2016.

101 "El Obispo de Roma no descansará mientras haya hombres y mujeres, de cualquier religión, ofendidos en su dignidad, privados de lo necessário para la supervivência, sin futuro, forzados a la condición de. desplazados y refugiados.(Cf. FRANCISCO, Discurso a los participantes em la Plenaria de la Congregación para las Iglesias Orientales, 21 de novembro de 2013. Disponível em: $\quad<$ https://w2.vatican.va/content/francesco/es/speeches/2013/november/documents/papafrancesco_20131121_plenaria-congreg-chiese-orientali.html >. Acesso em 03 de fevereiro de 2016).

102 EG 213.

${ }^{103}$ EG 3. 
respeitadas sua dignidade, liberdade e autonomia. ${ }^{104}$ Não pode nem deve se apartar de seus pares, sob pena de solidão, de culto ao indiferentismo, de culto ao individualismo, de culto à segregação, cujo fim inevitavelmente desemboca na tristeza individualista, na consciência isolada ${ }^{105}$, na cultura do descarte. ${ }^{106}$

Dentre esse elenco de pessoas que merecem ser amadas e acolhidas vislumbramos as pessoas com deficiência, elas também vítimas do preconceito e da exclusão que está beirando a eugenia, pois como diz o Bispo de Roma “infelizmente a sociedade está poluída pela cultura do "descarte” que se opõe ao acolhimento. As vítimas dessa cultura são precisamente as pessoas mais débeis, mais frágeis, ${ }^{107}$ como as pessoas com deficiência”. Em seu discurso aos membros do instituto Dignitatis Humanae Francisco deixa claro que a dignidade humana está centrada na criação do homem a imagem e semelhança de Deus.

O vosso Instituto propõe-se promover a dignidade humana com base na verdade fundamental de que o homem é criado à imagem e semelhança de Deus. Por conseguinte, uma dignidade originária de cada homem e mulher, insuprimível, indisponível para qualquer poder ou ideologia. Infelizmente na nossa época, tão rica de conquistas e esperanças, não faltam poderes e forças que acabam por produzir uma cultura do descarte; e esta tende a tornar-se mentalidade comum. As vítimas de tal cultura são precisamente os seres humanos mais débeis e frágeis os nascituros, os mais pobres, os idosos doentes, os deficientes graves... - que correm o risco de ser «descartados», expulsos de uma engrenagem que deve ser eficiente a todo o custo. Este falso modelo de homem e de sociedade actua um ateísmo prático negando de facto a Palavra de Deus que diz: «Façamos o homem à nossa imagem, à nossa semelhança» (cf. Gn 1, 26). ${ }^{108}$

Ainda nesse mesmo diapasão Francisco vai dizer que o relativismo é um dos sérios motivos pelos quais se descarta a vida, uma vez que a sociedade vive a

\footnotetext{
${ }^{104}$ FRANCISCO, Mensagem para a celebração do XLVIII Dia Mundial da Paz, 08 de dezembro de 2014. Disponível em: <http://w2.vatican.va/content/francesco/pt/messages/peace/documents/papa-

francesco_20141208_messaggio-xlviii-giornata-mondiale-pace-2015.html>. Acesso em 22 de maio de 2015.

105 Cf. EG 2.

106 Cf. FRANCISCO, Visita ao Parlamento Europeu, 25 de novembro de 2014. Disponível em: $<$ https://w2.vatican.va/content/francesco/pt/speeches/2014/november/documents/papafrancesco_20141125_strasburgo-parlamento-europeo.html >. Acesso em 14 de junho de 2015.

107 Cf. FRANCISCO, Encontro com as crianças com deficiências e os doentes do Instituto Seráfico, 04 de outubro de $2013 . \quad$ Disponível em: <http://w2.vatican.va/content/francesco/pt/speeches/2013/october/documents/papafrancesco_20131004_bambini-assisi.html>. Acesso em 25 de agosto de 2015.

108 FRANCISCO, Discurso aos membros do Instituto Dignitatis Humanae, 07 de dezembro de $2013 . \quad$ Disponível em: <http://m2.vatican.va/content/francesco/pt/speeches/2013/december/documents/papafrancesco_20131207_istituto-dignitatis.html>. Acesso em 28 de maio de 2015.
} 
cultura do efêmero, o usar e depois jogar fora. O ser humano é encarado como objeto, sendo visto como um bem de consumo, sendo tal a "coisificação" da vida que se chega ao ponto de descartar crianças que não correspondem ao desejo dos pais por nascerem com alguma deficiência.

A cultura do relativismo é a mesma patologia que impele uma pessoa a aproveitarse de outra e a tratá-la como mero objecto, obrigando-a a trabalhos forçados, ou reduzindo-a à escravidão por causa duma dívida. É a mesma lógica que leva à exploração sexual das crianças, ou ao abandono dos idosos que não servem os interesses próprios. É também a lógica interna daqueles que dizem: «Deixemos que as forças invisíveis do mercado regulem a economia, os seus efeitos sobre a sociedade e a natureza são danos inevitáveis». Se não há verdades objectivas nem princípios estáveis, fora da satisfação das aspirações próprias e das necessidades imediatas, que limites pode haver para o tráfico de seres humanos, a criminalidade organizada, o narcotráfico, o comércio de diamantes ensanguentados e de peles de animais em vias de extinção? Não é a mesma lógica relativista a que justifica a compra de órgãos dos pobres com a finalidade de os vender ou utilizar para experimentação, ou o descarte de crianças porque não correspondem ao desejo de seus pais? É a mesma lógica do «usa e joga fora» que produz tantos resíduos, só pelo desejo desordenado de consumir mais do que realmente se tem necessidade. Portanto, não podemos pensar que os programas políticos ou a força da lei sejam suficientes para evitar os comportamentos que afectam o meio ambiente, porque, quando é a cultura que se corrompe deixando de reconhecer qualquer verdade objectiva ou quaisquer princípios universalmente válidos, as leis só se poderão entender como imposições arbitrárias e obstáculos a evitar. ${ }^{109}$

Francisco acentua caber à Igreja se pronunciar sobre tais realidades em razão de que a "defesa da vida nascente está intimamente ligada à defesa de qualquer direito humano" 110 e afirma que o ser humano é sempre sagrado e inviolável, em qualquer situação, e em qualquer etapa de sua vida, embora reconheça que, assim agindo, a Igreja torna-se alvo de protestos, sendo taxada de obscurantista, ideológica e conservadora. ${ }^{111}$

Elucida e exorta a que sempre se procure respeitar a centralidade, a dignidade e o valor supremo da pessoa humana em todas as fases de sua existência ${ }^{112}$, desde a concepção até a morte ${ }^{113}$, rejeitando a "cultura da morte",

\footnotetext{
${ }^{109}$ LS 123.

110 EG 213.

111 Ibid.

112 EG 242.

113 A partilha fraterna com os doentes abre-nos à verdadeira beleza da vida humana, que inclui também a sua fragilidade, de modo que possamos reconhecer a dignidade e o valor de cada ser humano, seja qual for a condição na qual se encontre, desde a concepção até à morte. (Cf. FRANCISCO, Aos participantes no Congresso da Sociedade de Cirurgia Oncológica promovido pela Universidade "La Sapienza” de Roma, 12 de abril de 2014).
} 
uma luta que é enfrentada pela Igreja ao longo da história e cujos invariáveis percalços dizem respeito ao egoísmo, à fraqueza humana e a concupiscência que nos é comum. ${ }^{114}$

A paz é ferida ainda por toda e qualquer negação da dignidade humana e, primariamente, pela impossibilidade de se alimentar de forma suficiente. Não podem deixar-nos indiferentes os rostos de quantos padecem fome, sobretudo das crianças, se pensarmos quanta comida é desperdiçada cada dia em tantas partes do mundo, mergulhadas naquela que já várias vezes defini como a «cultura do descarte». Infelizmente, objecto de descarte não são apenas os alimentos ou os bens supérfluos, mas muitas vezes os próprios seres humanos, que acabam «descartados» como se fossem «coisas desnecessárias». Por exemplo, causa horror só o pensar que haja crianças que não poderão jamais ver a luz, vítimas do aborto, ou aquelas que são usadas?? como soldados, estupradas ou mortas nos conflitos armados, ou então feitas objecto de mercado naquela tremenda forma de escravidão moderna que é o tráfico dos seres humanos, que é um crime contra a humanidade. ${ }^{115}$

Portanto, a Igreja de Francisco posiciona-se contra o aborto e é com esse

pensamento, em favor da vida, que se necessário for, a Igreja no Brasil representada pela $\mathrm{CNBB}$, sairá em defesa dos microcéfalos, caso chegue ao Supremo Tribunal Federal, uma ação em que se arguirá pela descriminalização do aborto desses nascituros, pois:

Na realidade, à luz da fé e da recta razão, a vida humana é sempre sagrada e sempre <<de qualidade〉>. Não existe uma vida humana mais sagrada do que outra: cada vida humana é sagrada. Como não há vida humana qualitativamente mais significativa que outra. (...) a vida humana é sempre sagrada, válida e inviolável e como tal deve ser amada, defendida e cuidada. ${ }^{116}$

Em vista da violência letal o apelo do Bispo de Roma se faz sentir: "Não devemos matar o irmão precisamente porque ele é nosso irmão: temos o mesmo Pai" ${ }^{117}$ e a espiral da violência e do ódio se dissipa e se rompe "com uma única palavra: irmão". ${ }^{118}$

Disponível em: <http://w2.vatican.va/content/francesco/pt/speeches/2014/april/documents/papafrancesco_20140412_congresso-chirurgia-oncologica.html>. Acesso em 02 de abril de 2015.

${ }^{114}$ Cf. EG 263.

115 FRANCISCO, Discurso ao Corpo Diplomático acreditado junto a Santa Sé, 13 de janeiro de 2014. Disponível em: <http://w2.vatican.va/content/francesco/pt/speeches/2014/january/documents/papafrancesco_20140113_corpo-diplomatico.html>. Acesso em 19 de setembro de 2015.

${ }^{116}$ FRANCISCO, Aos participantes no Congresso da Associação dos médicos católicos italianos, 15 de novembro de 2014. Disponível em: <http://w2.vatican.va/content/francesco/pt/speeches/2014/november/documents/papafrancesco_20141115_medici-cattolici-italiani.html>. Acesso em 03 de fevereiro de 2016.

${ }^{117}$ FRANCISCO, Meditações matutinas na Santa Missa celebrada na capela da Domus Sanctae Marthae. Quando o ódio mata. 12 de junho de 2014. Disponível em: 
É com base nessa fraternidade, cujas raízes são divinas, que Francisco vai dizer que precisamos edificar, criar, construir, uma cultura do encontro, uma proposta que é o antídoto seguro contra a "cultura do descarte".

Ao fim, em grandes linhas, podemos afirmar que dentre alguns dos pontos exponenciais analisados tanto em Bergoglio quanto em Francisco, observamos que, permanecem vivas suas pretensões, seus desejos, suas idealizações. Portanto, a chave de leitura que se permite fazer em relação ao Pontificado de Francisco, está diretamente ligada ao "caminho" anteriormente traçado por Bergoglio, não havendo nem "desencontros" espirituais, nem "desencontros" de finalidades.

No próximo capítulo nos debruçaremos sobre o que vem a ser o ponto ápice de seu pensamento teológico espiritual: a misericórdia de um Deus que sempre nos espera e que não se cansa de nos perdoar.

<http://w2.vatican.va/content/francesco/pt/cotidie/2014/documents/papafrancesco_20140612_meditazioni-69.html>. Acesso em 22 de junho de 2015.

118 FRANCISCO, Palavras do Papa Francisco, Invocação pela paz, 8 de junho de 2014. Disponível em: <http://w2.vatican.va/content/francesco/pt/speeches/2014/june/documents/papafrancesco_20140608_invocazione-pace.html>. Acesso em 24 de junho de 2015. 


\section{A misericóridia: um dos pontos centrais da teologia de Francisco}

No primeiro capítulo introduzimos uma análise de alguns aspectos basilares tanto da teologia pastoral posta em ato por Bergoglio em seu arcebispado, quanto da teologia pastoral de Francisco em seu pontificado.

Foram abordados pontos fundamentais da teologia de Francisco a exemplo da opção preferencial pelos pobres, aqueles que o mundo exclui, mas que na verdade para a Igreja e para Deus são os primeiros. Restou claro que a dignidade de todo e qualquer ser humano não pode ser violada, e pessoas não podem ser descartadas.

A partir da exposição de seu pensamento teológico-pastoral é cabível dizer que no rol dos "pobres" desponta a pessoa com deficiência, cujo papel é preponderante no pensamento de Francisco, que chama a todos a olhar para essas pessoas com o olhar da misericórdia.

A fim de apresentar esta característica do pensamento de Francisco, estruturamos o presente capítulo que será dedicado ao tema da misericórdia, chave hermenêutica do seu pontificado e que intencionalmente omitimos no primeiro capítulo, a fim de que neste, seja dado ao tema à importância e consideração devidas. O tema será por nós apresentado com fundamento na teologia, na antropologia e na eclesiologia de Francisco.

O presente capítulo será estruturado em cinco partes assim divididas: a misericórdia: um coração para o mísero; a ternura como benevolência da misericórdia; a misericórdia divina; misericórdia humana; a Igreja da misericórdia e o Jubileu Extraordinário da Misericórdia.

Abordaremos o tema da misericórdia refletindo sobre o que vem a ser a misericórdia em Francisco, cujo pedido é que todos tenham um olhar misericordioso e terno em direção ao mísero. A misericórdia divina será analisada sobre o ângulo da ternura de Deus; a misericórdia humana será abordada a partir da "sabedoria do coração"; enfocaremos a visão eclesial de Francisco, cujo desejo se centra em uma Igreja misericordiosa para os pobres e que vá a todas as periferias existenciais e geográficas e nos remeteremos ao Jubileu Extraordinário da Misericórdia com a sua repercussão frente à pessoa com deficiência. 


\section{1}

\section{A misericórdia: um coração para o mísero}

O tema da Misericórdia não é novo, já tendo sido abordado pelos Papas que precederam Francisco. Mas em Francisco há um diferencial, pois que, justamente, o tema é sua plataforma espiritual. A misericórdia deve se manifestar por meio de uma ação concreta, preferentemente na ação pastoral, que tem como meta a opção preferencial pelos pobres.

A palavra misericórdia etimologicamente quer dizer "ter um coração para o mísero", identificado como aquela pessoa vítima da miséria material, da pobreza espiritual, cultural e relacional.

Para Francisco, olhar o pobre é olhá-lo de modo amigável, fraterno, afetivo e em uma única palavra que tudo exprime, é olhá-lo misericordiosamente. Portanto, esse olhar misericordioso se dirige ao pobre mais eminente dessa dissertação que é a pessoa com deficiência.

Há um chamado para que todos se espelhem nesse Deus misericordioso e se aproximem com misericórdia dos "lugares de sofrimento e de dor", abandonando o medo paralisante, pois há uma igualdade humana a qual todos partilham.

Nesses lugares de sofrimento e de dor, periferias existenciais e geográficas, se encontram os migrantes e refugiados, indígenas, camponeses, mulheres abandonadas, doentes, prostitutas, crianças de rua, drogados, inválidos, órfãos, encarcerados, aquele que é o excluído, o descartado, aquele que sofre vítima da cultura excludente.

Dentre esses feridos e necessitados de atenção e de amor, Francisco se dirige às famílias das pessoas com deficiência, pois a família é vista como lugar de misericórdia, de perdão, de bênçãos, onde se aprende a fraternidade. ${ }^{119}$

\footnotetext{
119 "Além disso, num mundo onde frequentemente se amaldiçoa, insulta, semeia discórdia, polui com as murmurações o nosso ambiente humano, a família pode ser uma escola de comunicação feita de bênção. E isto, mesmo nos lugares onde parecem prevalecer como inevitáveis o ódio e a violência, quando as famílias estão separadas entre si por muros de pedras ou pelos muros mais impenetráveis do preconceito e do ressentimento, quando parece haver boas razões para dizer «agora basta»; na realidade, abençoar em vez de amaldiçoar, visitar em vez de repelir, acolher em vez de combater é a única forma de quebrar a espiral do mal, para testemunhar que o bem é sempre possível, para educar os filhos na fraternidade. (...). A família onde as pessoas, apesar das próprias limitações e pecados, se amam, torna-se uma escola de perdão". (Cf. FRANCISCO, Mensagem de Sua Santidade Papa Francisco para o XLIX dia mundial das comunicações sociais, 23 de janeiro de 2015. Disponível em:
} 
Devemos ter por essas pessoas a máxima misericórdia, sabendo que um filho com deficiência não é castigo de Deus, muito pelo contrário, é exatamente através dele que a obra de Deus manifesta (João 9,3). ${ }^{120}$

O pedido de Francisco é no sentido de que os fiéis tenham compaixão misericordiosa por aqueles que vivem nas mais variadas periferias existenciais ${ }^{121}$, pois devemos realmente estar ao lado dos que sofrem e acompanhá-los amorosamente, não nos esquecendo das palavras de São João da Cruz: "No entardecer da vida, seremos julgados no amor". ${ }^{122}$

A misericórdia está para além de dar aquilo que cada qual merece, pois, em Francisco, essa "justiça" se dá na partilha fraterna, e não como consequência da lei ou de legalismos. Por outro lado, a misericórdia é fruto do amor assim como o perdão. ${ }^{123}$

Se a misericórdia humana não se fundamenta na lei, tampouco a misericórdia divina se fundamenta no decreto, "vai para além da lei e perdoa acariciando as feridas dos nossos pecados", pois diz Francisco: "Deus perdoa não com um decreto, mas com um gesto de carinho". 124

As palavras de Francisco tocam o coração de cristãos e não cristãos pela afirmação de que há um Deus misericordioso e paciente, que não abandona ninguém e que oferece a todos um novo recomeço, por pura misericórdia,

\footnotetext{
<https://w2.vatican.va/content/francesco/pt/messages/communications/documents/papafrancesco_20150123_messaggio-comunicazioni-sociali.html >. Acesso em 23 de abril de 2015). ${ }^{120} \mathrm{~J}$. Gevaert em seu livro Mal e sofrimento interrogam se põe a perguntar se afinal ter um filho com deficiência é castigo de Deus atestando que a resposta dada por Jesus sinaliza para a manifestação das obras de Deus. De toda forma, o autor entende que os pais de pessoas com deficiência precisam ser acolhidos com caridade, ajuda e suporte, pois geralmente sofrem de uma infundada vergonha frente aos outros genitores que não tem filhos com deficiência. $\mathrm{O}$ testemunho desses pais que vivem um espírito de profunda dedicação e sacrifício em relação ao filho com deficiência deveria ser para todos os cristãos, uma confirmação na fé e encorajamento a viver no serviço de caridade em relação a essas pessoas; um convite a caridade e a ajuda, pois, esse é o lugar onde obras de Deus se manifestam. "Bisogna avere uma enorme sensibilità per questi genitori che hanno um figlio handicappato. Spesso soffrono di uma infondata vergogna di fronte ad altri genitori che hanno figli sani da ogni punto de vista. La testimonianza di questi genitori che vivono uno spirito profondo di dedizione e di sacrifício verso questo figlio handicappato dovrebbe essere per tutti cristiani una conferma nella própria fede e incoraggiamento a non vivere meno nel servizio di carità verso queste persone. Dovrebbe essere soprattutto um invito allá carità, all'aiuto e al sostegno. Tutto cio insieme è um luogo dove le opere di Dio si manifestano". (Cf. GEVAERT, J., Male e sofferenza interrogano. Torino: Elledici, 2000, p. 151).

${ }^{121}$ MV 15.

${ }^{122}$ FRANCISCO, O nome de Deus é misericórdia. São Paulo: Planeta, 2016, p. 138.

${ }^{123}$ Cf. AL 27.

${ }^{124}$ FRANCISCO, O nome de Deus é misericórdia, p. 19.
} 
bastando para tanto um primeiro e único passo: reconhecer que necessitamos de misericórdia $^{125}$.

Francisco não mede gestos e palavras para expressar seu desejo por um mundo mais misericordioso começando por ele mesmo. ${ }^{126}$ No abraço, que lhe é peculiar, toca a carne do irmão. Crianças, doentes, pessoas com deficiência, anciãos, pessoas privadas de liberdade, migrantes, africanos, todos são portadores de seu abraço. ${ }^{127}$ E por isso, é visto por seus fiéis como o Papa da Misericórdia ${ }^{128}$, aquele profeta que traz na bagagem a revolução da misericórdia e do amor $^{129}$, e que profetiza um mundo novo.

É a profecia de um mundo novo: misericórdia é profecia de um mundo novo, no qual os bens da terra e do trabalho serão distribuídos igualmente e ninguém será privado do necessário, porque a solidariedade e a partilha são a consequência concreta da fraternidade. ${ }^{130}$

\begin{abstract}
${ }^{125}$ Ibid. p. 16.
${ }^{126}$ O Cardeal Dom Cláudio Hummes, ao comentar a viagem de Francisco a Lampedusa, assim se expressa: "Francisco ouviu o clamor surdo desses desesperados. Decidiu ir pessoalmente a Lampedusa, num impulso interior de misericórdia. Como Papa, foi sua primeira viagem fora de Roma. Ele quis, assim, marcar seu pontificado, desde o início, com o signo da misericórdia". Cf. HUMMES, C., Ano Santo da Misericórdia. Um Jubileu extraordinário. São Paulo: Paulus, 2015, p. 17.

${ }^{127}$ O artigo do teólogo jesuíta Víctor Codina descreve o abraço de Francisco como um abraço libertador e nesse sentido profético. Para além das sete obras de misericórdia corporal: dar de comer a quem tem fome; dar de beber a quem tem sede; vestir os nus; dar abrigo aos peregrinos; assistir os enfermos; visitar os cativos; enterrar os mortos, que são a face visível das pastorais de todas as Igrejas, Víctor Codina eleva o abraço de Francisco ao nível pastoral: "Não é simplesmente um abraço pastoral, é algo mais profundo, a pastoral do abraço. É um abraço que tem um profundo sentido profético de denúncia de um sistema que descarta e exclui", escreve o teólogo jesuíta Víctor Codina. O Papa Francisco acrescentou a estes métodos pastorais um caminho pastoral novo: a pastoral dos gestos significativos e, concretamente, a pastoral do abraço. Desde o início de seu pontificado, Francisco realizou gestos muito significativos (não residir nos Palácios apostólicos vaticanos, vestir e viajar de forma simples, ir a Lampedusa...), mas, principalmente, abraçando crianças e doentes, anciãos e mendigos, gente com diferentes capacidades físicas, imigrantes africanos e asiáticos. (...) E em sua recente viagem a América Latina também abraçou a homens e mulheres privados de liberdade e a todos os que se aproximaram dele para lhe manifestar seu testemunho e seus pedidos. (...) Por isso, Francisco abraça especialmente aqueles que não têm quem os abrace, os solitários, os marginalizados, os descartados, os feridos do caminho. E a estes manifesta a ternura e o carinho de Deus. (Cf. CODINA V., A pastoral do abraço do Papa Francisco. In: Unisinos. 21 de julho de 2015 Disponível em: <http://www.ihu.unisinos.br/noticias/544803-a-pastoral-do-abraco-do-papa-francisco>. Acesso em 22 de novembro de 2015).

${ }^{128}$ C. HUMMES, C., Ano Santo da Misericórdia um Jubileu extraordinário, p. 9.

${ }^{129}$ Cf. KASPER, W., Papa Francesco. La rivoluzione della tenerezza e dell'amore, pp. 24-25.

${ }^{130}$ FRANCISCO, Encontro com os cidadãos e proclamação do ano jubilar celestiano, 05 de julho de $2014 . \quad$ Disponível em: <http://w2.vatican.va/content/francesco/pt/speeches/2014/july/documents/papafrancesco_20140705_molise-indizione-anno-celestiniano.html>. Acesso em 30 de junho de 2016.
\end{abstract}


Francisco nos convida a conhecer a misericórdia de Deus que quis compartilhar nossa condição humana e assim habitou "na nossa história como ela é, com todo o peso de seus limites e seus dramas"; ${ }^{131}$ entrando na nossa história tornou-se plenamente Deus-conosco. ${ }^{132}$ Dessa forma Deus demonstra a Sua inconteste misericórdia e o amor que tem pelas criaturas. ${ }^{133}$

Assim Deus está Deus conosco, Deus que nos ama, Deus que caminha conosco. (...) Deus é solidário com o homem e com sua história. Esta proximidade de Deus ao homem, a cada um de nós, é um dom que nunca acaba. Ele está conosco! Ele é Deus conosco! E esta proximidade nunca acaba. ${ }^{134}$

Francisco atesta que a humanidade está ferida e precisa da misericórdia divina, pois não acredita na possibilidade de curar as feridas, que se originam na pobreza, na exclusão, no relativismo. Além do mais, não acredita no amor, vez que não vê a sua volta quem possa auxiliá-la, entendê-la; não encontra quem seja generoso; "falta a experiência concreta da misericórdia": 135

Hoje há necessidade de pessoas que sejam testemunhas da misericórdia e da ternura do Senhor, que incentiva os resignados, reanima os desanimados, acende o fogo da esperança. Ele acende o fogo da esperança! Não nós. Tantas situações exigem o nosso testemunho confortador. Ser pessoas jubilosas, consoladas. Penso em quantos estão oprimidos por sofrimentos, injustiças e abusos! (...) Coitados! Têm consolações mascaradas, não a verdadeira do Senhor! Todos estamos chamados a confortar os nossos irmãos, testemunhando que só Deus pode eliminar as causas dos dramas existenciais e espirituais. Ele pode fazê-lo! É poderoso! ${ }^{136}$

Ao longo do seu pontificado o tema da misericórdia vem sendo refletido paulatinamente, de forma que, tendo como base a sua doutrina teológica, é possível afirmar que a misericórdia divina reflete a ternura de Deus.

Francisco define o que é misericórdia ao responder a pergunta de Andrea Tornelli em seu livro "O nome de Deus é misericórdia". Para Francisco a Misericórdia tem um significado: a misericórdia é a identidade de Deus. ${ }^{137}$ É Deus quem se dá ao homem, o aceita e o perdoa. ${ }^{138}$ Ao concluir Francisco diz que a misericórdia está profundamente enraizada na fidelidade de Deus que não se

${ }^{131}$ FRANCISCO, Jesus sempre nos espera. Brasília: Edições CNBB, 2014, p. 22.

${ }^{132}$ Cf. Ibid 44.

${ }^{133}$ Cf. Ibid 22.

${ }^{134}$ FRANCISCO, Jesus sempre nos espera, pp. 44-45.

${ }^{135}$ FRANCISCO, O nome de Deus é misericórdia, p. 46.

${ }^{136}$ FRANCISCO, Angelus, 7 de dezembro de 2014. Disponível em: <https://w2.vatican.va/content/francesco/pt/angelus/2014/documents/papafrancesco_angelus_20141207.html>. Acesso em 03 de julho de 2016.

${ }^{137}$ Cf. FRANCISCO, O nome de Deus é misericórdia, p. 37

${ }^{138}$ Cf. Ibid. 37. 
engana nem nos engana: podemos pecar contra Deus e mentir, mas Ele sempre é e se mantém fiel. ${ }^{139}$

Esse é o convite de Francisco: que os homens se deixem amar por um Deus que é "ternura". Portanto, escolhemos discorrer sobre a misericórdia de Deus, vista sob o ângulo da ternura de Deus, seja na paternidade, seja em sua analogia com a maternidade, bem como em sua visão de que a ternura de Deus se evidencia nas suas "carícias divinas", no perdão. Essa misericórdia se reflete nos homens e tem na Igreja seu lugar de expressão por excelência.

\section{2}

\section{A ternura como benevolência da misericórdia divina}

A ternura como misericórdia é sinal da Aliança. Essa Aliança é feita entre Deus e o homem, pois Deus tem um desígnio de comunhão que se dá entre Ele e seu povo, e que é já experimentado aqui. Essa experiência leva Francisco a atestar que Deus surpreende com seu amor, fidelidade e misericórdia:

Ele é o nosso Deus! Ele é o Deus de cada um de nós! Como se Ele tivesse o nosso nome. Ele gosta de o dizer, e esta é a aliança. E este é o vínculo decisivo, a aliança fundamental embelezamento desta actual: ela supera a nossa imaginação, porque Deus nos surpreende continuamente com o seu amor e com a sua misericórdia. (...) À nossa frente está o Deus dos vivos, o Deus da aliança, o Deus que traz o meu nome, o nosso nome, como Ele mesmo disse: «Eu sou o Deus de Abraão, de Isaac e de Jacob», também é o Deus que traz o meu nome, o teu nome, o nome de cada um..., o nosso nome. O Deus dos vivos! (...) À nossa frente está a derrota definitiva do pecado e da morte, o início de um novo tempo de alegria e de luz sem fim. Mas já nesta terra, na oração, nos Sacramentos e na fraternidade. (...) Com efeito, se Deus é fiel e ama, não pode sê-lo a tempo limitado: a fidelidade é eterna, não pode mudar. O amor de Deus é eterno, não pode mudar! Não é a tempo limitado: é para sempre! É para ir em frente! Ele é fiel para sempre e espera-nos, espera cada um de nós, acompanha cada um de nós com esta fidelidade eterna. ${ }^{140}$

Apesar da Aliança divina o homem deixando-se enganar foge de Deus. Por isso, Francisco convida os fiéis para que renovem a Aliança com esse Deus cujo amor é eterno e cuja fidelidade é imutável, e que para além de tudo nunca se cansa de perdoar; são os homens que se cansam de pedir a Sua misericórdia. ${ }^{141}$

\footnotetext{
${ }^{139}$ Cf. Ibid. 38.

${ }^{140}$ FRANCISCO, Angelus, 10 de Novembro de 2013. Disponível em: <http://w2.vatican.va/content/francesco/pt/angelus/2013/documents/papafrancesco_angelus_20131110.html >. Acesso em 04 de julho de 2016. ${ }^{141}$ Cf. EG 3.
} 
Deus traz o nome dos seus em Seu nome, em sinal de herança e posteridade eterna. Esse Deus que é Pai é Aquele em quem Francisco deposita toda a sua confiança, pois, ele é um Pai que ama e a quem não se deve temer, e por cujos braços é necessário deixar-se conduzir. Deus é um Pai que quer a salvação de todos, pois ama a seus filhos de todo coração ${ }^{142}$ e nisto consiste a misericórdia de Deus $^{143}$, cheio de bondade, ternura, perdão, carícias e afagos que penetram os corações.

Um Deus cuja identidade é a terna misericórdia, que sempre está perto, que sempre acompanha; um Deus que carrega em Si a vontade e o poder de ser próximo; um Deus cujo Nome se interpenetra em todos os nomes e, assim, se afirma e se confirma a sua existência; um Deus que ama com ternura.

Ternura! Mas o Senhor ama-nos com ternura. O Senhor sabe aquela bela ciência do carinho, aquela ternura de Deus. Não nos ama com palavras. Ele aproxima-se proximidade - e dá-nos aquele amor com ternura. Proximidade e ternura. Estas duas maneiras do amor do Senhor que se faz próximo e dá todo o seu amor mesmo com as menores coisas: com ternura. E este é um amor forte, porque a proximidade e a ternura fazem-nos ver a fortaleza do amor de Deus. ${ }^{144}$

Esse Deus deve ser ouvido, pois não ouvi-Lo é estar longe da alegria do seu amor, e dessa forma a vida interior se retrai, havendo um fechamento em si mesmo, o individualismo que leva a indiferença e não deixa que a solidariedade para com os mais vulneráveis tenha lugar. ${ }^{145}$

Em “O nome de Deus é misericórdia”, Francisco passa a expor o que é, no seu modo de ver, a misericórdia divina e como Deus a exerce: “Assim é a misericórdia de Deus: uma grande luz de amor e ternura". ${ }^{146}$ Esse amor de Deus

142 Cf. FRANCISCO, Audiência Geral, 11 de junho de 2014. Disponível em: $<$ https://w2.vatican.va/content/francesco/pt/audiences/2014/documents/papa-

francesco_20140611_udienza-generale.html>. Acesso em 03 de julho de 2016.

${ }^{143}$ A misericórdia de Deus: como é bela esta realidade da fé para a nossa vida! Como é grande e profundo o amor de Deus por nós! É um amor que não falha, que sempre agarra a nossa mão, nos sustenta, levanta e guia. (...). Quanta ternura! Irmãos e irmãs, não percamos jamais a confiança na paciente misericórdia de Deus! (...). Amados irmãos e irmãs, deixemo-nos envolver pela misericórdia de Deus; confiemos na sua paciência, que sempre nos dá tempo; tenhamos a coragem de voltar para sua casa, habitar nas feridas do seu amor deixando-nos amar por Ele, encontrar a sua misericórdia nos Sacramentos. Sentiremos a sua ternura maravilhosa, sentiremos o seu abraço, e ficaremos nós também mais capazes de misericórdia, paciência, perdão e amor. (Cf. FRANCISCO, Homilia Do Santo Padre. II Domingo de Páscoa ou da Divina Misericórdia, 7 de abril de 2013. Disponível em: <http://w2.vatican.va/content/francesco/pt/homilies/2013/documents/papafrancesco_20130407_omelia-possesso-cattedra-laterano.html>. Acesso em 04 de julho de 2016.

${ }^{144}$ FRANCISCO, A verdade é um encontro. São Paulo: Paulinas, 2015, p. 179.

145 Cf. EG 2

${ }^{146}$ Cf. FRANCISCO, O nome de Deus é misericórdia, p. 23 
se dá na proximidade com seu povo; é um Deus que se deixa encontrar e aquele que $\mathrm{O}$ encontra, se contagia com sua alegria.

\subsection{1}

\section{A misericórdia divina na ternura paternal}

Em 17 de março de 2013, em seu primeiro Angelus ${ }^{147}$ Francisco endereçou ao mundo a seguinte mensagem: "Um pouco de misericórdia torna o mundo menos frio e mais justo. Precisamos de (sic) compreender bem esta misericórdia de Deus, este Pai misericordioso que tem tanta paciência..." 148 porque é grande a sua misericórdia:

Irmãos e irmãs, o rosto de Deus é o de um pai misericordioso, que sempre tem paciência. Já pensastes na paciência de Deus, na paciência que Ele tem com cada um de nós? É a sua misericórdia. Sempre tem paciência, tanta paciência connosco: compreende-nos, está à nossa espera; não se cansa de nos perdoar, se soubermos voltar para Ele com o coração contrito. «Grande é a misericórdia do Senhor», diz o Salmo. ${ }^{149}$

Nesse mesmo dia em sua primeira homilia dominical Francisco deixa claro o que para ele representa a misericórdia de Deus: "A meu ver - humildemente o afirmo -, é a mensagem mais forte do Senhor: a misericórdia". ${ }^{150}$

$\mathrm{O}$ amor misericordioso de Deus é biblicamente narrado na pessoa do Pai ${ }^{151}$ e as maravilhas salvíficas desse amor e desse Pai estão nas Escrituras. Dentre essas narrações Francisco acena para aquelas em que brilham o amor e a paternidade de Deus, que Deus nunca se cansa de perdoar. ${ }^{152} \mathrm{O}$ nosso Deus que é

\footnotetext{
${ }^{147} \mathrm{O}$ cardeal Kasper, citado por Francisco justo no Angelus acima mencionado, assevera que em Francisco, lançam-se fora as cinzas acumuladas de muitos séculos, e dessa forma, abre-se o caminho para uma nova hermenêutica em relação ao Evangelho. Essa hermenêutica centra-se na misericórdia, sendo a partir daí que se interpretam todas as verdades e mandamentos bíblicos. (Cf. KASPER, W., Testimone della Misericordia. Il mio viaggio con Francesco, pp. 11-13).

${ }^{148}$ FRANCISCO, Angelus, 17 de março de 2013. Disponível em: <http://w2.vatican.va/content/francesco/pt/angelus/2013/documents/papafrancesco_angelus_20130317.html>. Acesso em 04 de julho de 2016.

149 Ibid.

150 FRANCISCO, Homilia, V Domingo de Quaresma, 17 de Março de 2013. Disponível em: $<$ http://w2.vatican.va/content/francesco/pt/homilies/2013/documents/papafrancesco_20130317_omelia-santa-anna.html>. Acesso em 03 de julho de 2016.

${ }^{151}$ Não podemos esquecer que "a misericórdia não é apenas o agir do Pai, mas torna-se o critério para individuar quem são os seus verdadeiros filhos. Em suma, somos chamados a viver de misericórdia, porque, primeiro, foi usada misericórdia para conosco". (Cf. AL 310).

152 EG 3.
} 
Pai é Aquele que espera pelo filho pródigo, Aquele que todos os dias subia na esperança de que ele voltasse. ${ }^{153}$

Esse Pai espera, é próximo e paciente ${ }^{154}$, espera pelo filho, procura-o, amao, perdoa-o, quer estar a seu lado ${ }^{155}$, porque ele é o Senhor que toma a iniciativa de ir ao encontro daqueles que estão afastados, é ele que Se doa e que convida os excluídos ${ }^{156}$ a um "encontro" fraterno de união com Deus Pai, de Quem deriva toda a paternidade. ${ }^{157}$ Francisco assim explica a relação que há entre a fraternidade e a paternidade divina.

A raiz da fraternidade está contida na paternidade de Deus. Não se trata de uma paternidade genérica, indistinta e historicamente ineficaz, mas do amor pessoal, solícito e extraordinariamente concreto de Deus por cada um dos homens (cf. Mt 6, 25-30). Trata-se, por conseguinte, de uma paternidade eficazmente geradora de fraternidade, porque o amor de Deus, quando é acolhido, torna-se no mais admirável agente de transformação da vida e das relações com o outro, abrindo os seres humanos à solidariedade e à partilha activa. ${ }^{158}$

Em sua Exortação Apostólica Evangelii Gaudium Francisco lembra aos fiéis o amor misericordioso do Pai e solicita a eles que realizem obras de justiça e de caridade, para que a Palavra se torne fecunda, ${ }^{159}$ asseverando que, até as pessoas que tem erros a que se criticar, tem algo a oferecer que não se deve perder ${ }^{160}$, porque diz ele, existe no Evangelho uma congregação universal, um critério de

\footnotetext{
${ }^{153}$ Francisco em sua Homilia em Santa Marta, se remete a passagem do Evangelho que fala sobre o filho pródigo "que se tinha ido embora com muito dinheiro, com toda a herança. Como sabemos que o esperava?" perguntou o Papa Francisco. Porque - é a resposta que nos dão as escrituras "o viu de longe. E porque todos os dias subia na esperança» que o filho voltasse. Com efeito, naquele pai misericordioso está “o nosso Deus", que "é pai". (Cf. FRANCISCO, Quando o Senhor chora, 06 de fevereiro de 2014. Disponível em: <http://w2.vatican.va/content/francesco/pt/cotidie/2014/documents/papafrancesco_20140206_meditazioni-35.html>. Acesso em 04 de julho de 2016.

${ }^{154}$ A paciência é uma qualidade do Deus da Aliança ao mesmo tempo que se louva a moderação de Deus para dar tempo ao arrependimento, insiste-se no seu poder que se manifesta quando actua com misericórdia. A paciência de Deus é exercício da misericórdia de Deus para com o pecador e manifesta o verdadeiro poder. (Cf. AL 91).

${ }^{155}$ FRANCISCO, Quando o senhor chora, 06 de fevereiro de 2014.

${ }^{156}$ Cf. EG 24.

${ }^{157}$ FRANCISCO, Santa Missa de Crisma, 17 de Abril de 2014. Disponível em: <http://w2.vatican.va/content/francesco/pt/homilies/2014/documents/papafrancesco_20140417_omelia-crisma.html>. Acesso em 01 de julho de 2016.

${ }^{158}$ FRANCISCO, Mensagem para a celebração do XLVII Dia Mundial da Paz, $1^{\circ}$ de janeiro de 2014. Disponível em: <http://w2.vatican.va/content/francesco/pt/messages/peace/documents/papafrancesco_20131208_messaggio-xlvii-giornata-mondiale-pace-2014.html>. Acesso em 03 de julho de 2016.

${ }^{159}$ Cf. EG 233.

${ }^{160}$ Cf. EG 236.
} 
totalidade que lhe é intrínseco ${ }^{161}$, que denota a misericórdia divina, pois que o Pai não quer que se perca nenhum dos seus pequeninos. ${ }^{162}$

O amor do Pai se reflete em seus filhos e torna a suas ações misericordiosas e alegres, uma alegria presente nas coisas simples do dia a dia, pois essa alegria tem sua origem fundante em Deus, cuja ternura chama o homem à felicidade ${ }^{163}$ eterna porque eterna é a sua misericórdia.

Eterna é a sua misericórdia: tal é o refrão que aparece em cada versículo do Salmo 136, ao mesmo tempo que se narra a história da revelação de Deus. Em virtude da misericórdia, todos os acontecimentos do Antigo Testamento aparecem cheios dum valor salvífico profundo. A misericórdia torna a história de Deus com Israel uma história da salvação. O facto de repetir continuamente «eterna é a sua misericórdia», como faz o Salmo, parece querer romper o círculo do espaço e do tempo para inserir tudo no mistério eterno do amor. É como se se quisesse dizer que o homem, não só na história, mas também pela eternidade, estará sempre sob o olhar misericordioso do Pai. ${ }^{164}$

Por isso devemos ser "Misericordiosos como o Pai", lema do Ano Santo que está em curso; um Pai que se entrega e ama com ternura, um Pai cuja misericórdia não se acaba e cuja compaixão é inesgotável. ${ }^{165}$

\section{2 .2}

\section{A misericórdia divina na ternura maternal}

Falar do amor divino como realidade materna não fica evidenciado em muitas passagens bíblicas, mas Francisco faz uma relação da misericórdia divina com a maternidade, pois Deus salva o povo sendo próximo e nos ama como uma mãe, falando com seu povo da mesma maneira que uma mãe fala com seu filho. Dessa mesma forma se expressa à ternura de Deus por seu povo.

Quando de sua viagem ao Brasil na Jornada Mundial da Juventude, Francisco vai falar de uma Igreja capaz de redescobrir as entranhas maternas da misericórdia, ${ }^{166}$ acenando claramente para essa qualidade própria da misericórdia

${ }^{161}$ Cf. EG 237.

162 Ibid.

${ }_{163}^{163}$ Cf. EG 4.

${ }^{164}$ MV 7.

${ }^{165}$ Cf. EG 6.

166 “ Por isso, faz falta uma Igreja capaz de redescobrir as entranhas maternas da misericórdia. Sem a misericórdia, poucas possibilidades temos hoje de inserir-nos em um mundo de «feridos», que têm necessidade de compreensão, de perdão, de amor". (Cf. FRANCISCO, Encontro com o Episcopado Brasileiro, 27 de julho de 2013. Disponível em: 
que é a ternura da mãe e que move a Igreja inteira para que saia em missão, movida por entranhas da misericórdia. ${ }^{167}$

Enfim, gostaria que, graças à experiência fundante do amor familiar, o homem crescesse também na sua abertura a Deus como Pai. Por esse motivo, o Documento de Aparecida afirma que a família não deve ser considerada só objeto de evangelização mas também agente de evangelização.(...). Nela reflecte-se a imagem de Deus que no seu mistério mais profundo é uma família e, deste modo, permite ver o amor humano como sinal e presença do amor divino (cf. Carta Encíclica Lumen fidei, 52). ${ }^{168}$

A misericórdia divina também tem relação com as famílias. Assim estipula Francisco ao dizer que na família é que se reflete a imagem de Deus no seu mais profundo mistério e evidencia que, o princípio da unidade da família humana, se funda na paternidade de Deus Criador e na fraternidade dos seres humanos. ${ }^{169}$

\subsection{3}

\section{A misericórdia divina na ternura das carícias: o perdão}

Ao Deus de misericórdia não se deve temer diz Francisco, porque $\mathrm{O}$ mesmo é um Deus consolador e ao sentir a Sua consolação se sente também a Sua ternura. Não se deve ter medo ${ }^{170}$ de Deus, pois Ele é misericórdia, é ternura.

<http://w2.vatican.va/content/francesco/pt/speeches/2013/july/documents/papafrancesco_20130727_gmg-episcopato-brasile.html>. Acesso em 02 de julho de 2016. ${ }^{167}$ Cf. FRANCISCO, Discurso aos Bispos da Conferência Episcopal de Timor Leste em Visita "Ad Limina Apostolorum", 17 de março de 2014. Disponível em: <http://w2.vatican.va/content/francesco/pt/speeches/2014/march/documents/papafrancesco_20140317_ad-limina-timor-est.html>. Acesso em 29 de junho de 2016.

168 FRANCISCO, Mensagem por ocasião do I Congresso latino-mericano de pastoral familiar que se celebra de 4 a 9 de agosto na cidade do Panamá, 08 de agosto de 2014. Disponível em: < http://w2.vatican.va/content/francesco/pt/messages/pontmessages/2014/documents/papa-francesco_20140508_messaggio-i-congresso-celam-pastoralefamiliare.html>. Acesso em 01 de julho de 2016.

${ }^{169}$ FRANCISCO, Visita à FAO por ocasião da II Conferência Internacional sobre a alimentação, 20 de novembro de 2014.2 Disponível em: <http://w2.vatican.va/content/francesco/pt/speeches/2014/november/documents/papafrancesco_20141120_visita-fao.html >. Acesso em 30 de junho de 2016.

170 Algumas vezes encontrei pessoas consagradas que têm medo da consolação de Deus e... pobrezinho, pobrezinha delas, se amofinam porque têm medo desta ternura de Deus. Mas não tenhais medo. Não tenhais medo, o nosso Deus é o Senhor da consolação, o Senhor da ternura. O Senhor é Pai e Ele disse que procederá conosco como faz uma mãe com o seu filho, com a ternura dela. Não tenhais medo da consolação do Senhor.(Cf. FRANCISCO, Santa Missa com os seminaristas, noviços, noviças e quantos estão em caminhada vocacional, 07 de julho de 2013. Disponível em: <http://m2.vatican.va/content/francesco/pt/homilies/2013/documents/papafrancesco_20130707_omelia-seminaristi-novizie.html>. Acesso em 04 de julho e 2016. 
Francisco ao fazer referência à misericórdia de Deus na dimensão do perdão estabelece uma maneira "trina" de expressá-la. Em Francisco o perdão de Deus se verifica por meio da ternura e é experimentado por meio de "carícias" divinas; perdão, ternura e carícias, pois "é grande a misericórdia de Deus: perdoar-nos, acariciando-nos". ${ }^{171}$ Essa é a atitude divina do doar-se de Deus. A esse Deus todos devem acolher.

Como acolhemos a ternura de Deus? Deixo-me alcançar por Ele, deixo-me abraçar, ou impeço-Lhe de aproximar-Se? "Oh não, eu procuro o Senhor!" - poderíamos replicar. Porém a coisa mais importante não é procurá-Lo, mas deixar que seja Ele a procurar-me, a encontrar-me e a cobrir-me amorosamente das suas carícias. ${ }^{172}$

Seu olhar divino se volta para os doentes e para os pecadores e desse modo doa seu Ser misericordioso, que se abre ao coração do miserável, mostrando assim a gratuidade do seu amor. ${ }^{173}$

O perdão dos pecados é o que apaga os pecados e apenas Deus pode apagálos, mas a misericórdia divina vai além, vez que ela é feita com ternura, a ternura

${ }^{171}$ FRANCISCO, Meditações matutinas: Santa Missa capela casa Santa Marta. numa caricia, 07 de abril de 2014. Disponível em:

<https://w2.vatican.va/content/francesco/pt/cotidie/2014/documents/papafrancesco_20140407_meditazioni-46.html>. Acesso em 29 de junho de 2016.

172 FRANCISCO, Solenidade do Natal do Senhor, 24 de dezembro de 2014. Disponível em: $<$ http://w2.vatican.va/content/francesco/pt/homilies/2014/documents/papafrancesco_20141224_omelia-natale.html>. Acesso em 30 de junho de 2016.

${ }^{173}$ Em discurso as Misericórdias da Itália Francisco assim se expressa: As «Misericórdias», antiga expressão do laicado católico, e bem arraigadas no território italiano, estão comprometidas no testemunho do Evangelho da caridade entre os enfermos, os idosos, os portadores de deficiência, os menores, os imigrantes e os pobres. Todo o vosso serviço adquire sentido e forma a partir desta palavra: «misericórdia», palavra latina cujo significado etimológico é «miseris cor dare», «dar o coração aos miseráveis», a quantos estão em necessidade, àqueles que sofrem. (Cf. FRANCISCO, Discurso às Misericórdias da Itália e aos grupos 〈〈Fratres〉> no $30^{\circ}$ aniversário da Audiência com o Papa João Paulo II, 14 de junho de 2014. Disponível em: <https://w2.vatican.va/content/francesco/pt/speeches/2014/june/documents/papa-

francesco_20140614_confederaz-misericordie-d-italia.html>. Acesso em 28 de maio de 2015. É interessante ressaltar a definição do cardeal Walter Kasper sobre a misericórdia, uma vez que Francisco em seu primeiro Angelus elogiou as palavras do cardeal em relação ao tema. Kasper diz que a palavra misericórdia significa ter um coração para o mísero quer seja o vítima de miséria material, de pobreza de relações, de pobreza espiritual e de pobreza cultural. Devemos mudar a situação do outro tanto quanto seja possível. E embora a justiça não seja o oposto da misericórida a misericórdia a transcende, sendo a justiça o respeito pela dignidade do ser humano dando a ele aquilo que lhe é de direito. Vejamos o que diz Kasper sobre a misericórdia: La parola misericordia vuol dire avere un cuore per il misero- misero in senso ampio, vittima non solo di una miseria materiale, ma anche della povertà di relazioni, povertà spirituale, povertà culturale. Essa non è solo atteggiamento fattivo: io devo cambiar la situazione dell'altro, per quanto mi è possibile. E tuttavia, la misericordia non è l'opposto della giustizia. La giustizia è um minimum, è quando dobbiamo fare per l'altro per rispettarne la dignità di essere umano, per dargli quello che lui deve avere. Ma la misericordia è il maximum, e trascende la pura giustizia. (Cf. KASPER, W., Testimone della misericordia. Il mio viaggio com Francesco, p. 14). 
divina, pois que Deus quer a nossa salvação que é oferecida aos homens em razão de Sua misericórdia ${ }^{174}$ e do Seu perdão: "Perdoa acariciando as nossas feridas de pecado, porque ele é todo perdão, comprometido com a nossa salvação"175, e, além disso, dá força e dá paz.

Vinde a mim todos vós que estais cansados e aliviar-vos-ei. Deus, disse Francisco, repete-nos continuamente: "Eu sou o Senhor teu Deus que te tomo pela mão, nada temas pequenino, não temas. Dar-te-ei a força. Dá-me tudo e perdoar-te-ei, dar-teei a paz". São estas, (...) "as carícias de Deus" do nosso Pai, quando se exprime com a sua misericórdia. ${ }^{176}$

Em relação ao perdão, Andrea Tornelli pergunta a Francisco porque ele sempre repete que Deus não se cansa de perdoar. Da resposta de Francisco brota o nome do seu livro. Francisco responde que Deus não se cansa de perdoar ${ }^{177}$ “porque é Deus, porque Ele é misericórdia, e porque a misericórdia é o primeiro atributo de Deus. É o nome de Deus". ${ }^{178}$

Os fiéis são chamados a se comover ${ }^{179}$ com a misericórdia divina, com o Deus misericordioso que acaricia a alma e é fonte de alegria, serenidade e paz ${ }^{180}$; Aquele que socorre o homem em seus momentos de dor.

São as mãos de Deus que nos acariciam no momento da dor, que nos confortam. É o nosso Pai que nos acaricia, que nos ama muito. E nestas carícias muitas vezes está o perdão. (...) Repreende-nos sim, porque o faz; mas nunca nos fere, jamais! Acaricia-nos. Até quando nos deve repreender, fá-lo com uma carícia, porque é Pai. ${ }^{181}$

\footnotetext{
${ }^{174}$ Cf. EG 112.

${ }^{175}$ Cf. FRANCISCO, O nome de Deus é misericórdia, p. 23.

${ }^{176} \mathrm{Cf}$ FRANCISCO, Meditações matutinas na Santa Missa celebrada na capela da casa Santa Marta. Carícia de pai, 10 de dezembro de 2015. Disponível em: <http://w2.vatican.va/content/francesco/pt/cotidie/2015/documents/papa-francescocotidie_20151210_caricia-de-pai.html>. Acesso em 04 de julho de 2015.

${ }^{177} \mathrm{EG} 3$.

${ }^{178}$ Cf. FRANCISCO, O nome de Deus é misericórdia, p. 122.

${ }^{179}$ Deixemos que o nosso coração se comova: não tenhamos medo disso. Não tenhamos medo que o nosso coração se comova! Precisamos que o nosso coração se comova. Deixemo-lo abrasar-se pela ternura de Deus; precisamos das suas carícias. As carícas de Deus não fazem feridas: as carícias de Deus dão-nos paz e força. Precisamos das suas carícias. (Cf. FRANCISCO, Mensagem Urbi et Orbi Natal 2013, 25 de dezembro de 2013. Disponível em : $<$ http://w2.vatican.va/content/francesco/pt/messages/urbi/documents/papa-

francesco_20131225_urbi-et-orbi-natale.html>. Acesso em 29 de junho de 2016. ${ }^{180}$ MV 2.

${ }^{181}$ FRANCISCO, Meditações matutinas na Santa Missa celebrada na capela da casa Santa Marta. A nossa esperança nas mãos seguras de Deus, 14 de novembro de 2013. Disponível em: <http://w2.vatican.va/content/francesco/pt/cotidie/2013/documents/papafrancesco_20131114_meditazioni-25.html>. Acesso em 30 de junho de 2016.
} 
Entretanto, existe um passo que deve ser dado para que a misericórdia de Deus possa ser experimentada, que é se reconhecer necessitado de misericórdia, diz Francisco, e completa dizendo que somente "na inocência, no abaixamento, podemos receber o amor de Deus", pois "se nos sentirmos fortes, nunca teremos a experiência das carícias tão boas do Senhor". ${ }^{182}$

A Igreja nesse tempo da misericórdia deve mostrar seu lado maternal, sua face de mãe à humanidade ferida, pois, a centralidade da misericórdia é a mensagem mais importante deixada por Jesus, ${ }^{183}$ que de fato mostra ao homem o quanto ele é importante e o quanto é amado. ${ }^{184}$ Nossa era é a era da misericórdia, é o Kairós da misericórdia, esse é o tempo oportuno. ${ }^{185}$ Uma Igreja que aqueça os corações com sua proximidade não apenas física, mas também espiritual". ${ }^{186}$

\section{3}

\section{A misericórdia humana: sabedoria do coração}

O tema sobre a misericórdia divina demonstrou que a fraternidade tem raízes na paternidade divina e que o homem que se abre a Deus a Ele se assemelha em razão da misericórdia do Pai, revelando por meio de seus atos, um coração alegre e misericordioso, muito embora não tendo permanecido indiferente a dor do outro.

Esse deixar-se comover pelo outro que sofre, essa capacidade de abraçar o outro na sua dor, é fruto de um coração humano, ${ }^{187}$ misericordioso e terno, moldado pelas mãos de Deus de quem o homem é imagem e semelhança. Exatamente por isso, a misericórdia humana se reveste de ternura de pai, de mãe, é aconchegante e acaricia aquele que sofre, fazendo-se sensível às suas necessidades.

\footnotetext{
${ }^{182}$ FRANCISCO, Meditações matutinas na Santa Missa celebrada na capela da casa Santa Marta. A canção de embalar de Deus, 27 de Junho de 2014. Disponível em: $\quad<$ http://w2.vatican.va/content/francesco/pt/cotidie/2014/documents/papafrancesco_20140627_meditazioni-77.html>. Acesso em 29 de junho de 2016.

${ }^{183}$ Cf. FRANCISCO, O nome de Deus é misericórdia, p. 34.

${ }^{184} \mathrm{Cf}$. Ibid.

${ }^{185}$ CF. Ibid. p. 35 .

${ }^{186}$ CF. Ibid. p. 37.

${ }^{187}$ O homem compassivo tem o coração aberto. Francisco ao referir-se ao Bom Samaritano diz que o homem que tem o coração fechado foge de Deus. Não foi o caso do samaritano: Ao contrário, um samaritano que estava de viagem, "viu e teve compaixão dele": tinha o coração aberto, era humano. E a humanidade o aproximou.(Cf. FRANCISCO. A verdade é um encontro, p. 279).
} 
O "próximo" é a medida da misericórdia humana, tendo na parábola do Bom Samaritano, ${ }^{188}$ o modelo por excelência de onde se parte para a atuação existencial, pois o samaritano tem um coração compassivo em relação àquele homem quase morto que encontrou na estrada.

O coração daquele samaritano é bondoso e generoso (...) ele pratica a vontade de Deus, que quer mais a misericórdia do que os sacrifícios (cf. $M c 12,33$ ). Deus quer sempre a misericórdia e não a condenação de todos. Quer a misericórdia do coração, porque Ele é misericordioso e sabe compreender bem as nossas misérias, as nossas dificuldades e até os nossos pecados. Dá a todos nós este coração misericordioso! O samaritano faz precisamente isto: imita a misericórdia de Deus misericórdia para com quem está em necessidade. ${ }^{189}$

É preciso agir, e agir com misericórdia: "ser com o que sofre" e ao mesmo tempo "ser para o que sofre". Discursos bonitos não devem estar acima da ação misericordiosa, pois a realidade que se vê é a do sofrimento e da dor. ${ }^{190} \mathrm{O}$ apelo pela misericórdia se dirige a todos. Sacerdotes e fiéis são chamados a agir e comportar-se, tendo diante de si uma ordem de amor, pois "a verdadeira misericórdia interessa-se pela pessoa, ouve-a atentamente, aproxima-se com

${ }^{188}$ KASPER, W., Papa Francesco. La rivoluzione della tenerezza e dell'amore, pp. 54-55. Kasper entende que o exemplo de misericórdia encontra resposta na parábola do samaritano, em que há um que necessita e um que assiste ao necessitado. A pergunta que surge na parábola sobre quem seja o próximo vem respondida de forma indutiva, pois, a ação se dirige a uma pessoa que naquele momento está necessitada; a misericórdia sempre se dirige a uma pessoa concreta, aquele a quem encontramos carente de nossa ajuda. Vejamos como Kasper se expressa: "Chi è il mio prossimo? La sua risposta non è deduttiva, ma indutiva, in quanto egli parte dalla situazione umana concreta. Il tuo prossimo è colui che tu incontri, che in una situazione há bisogno del tuo aiuto e della tua misericordia, sul quale tu ti devi chinare e le cui ferite tu devi fasciare. Para além disso, Kasper vai dizer que a misericórdia e a chave hermenêutica para a uma exegese que diga respeito tanto aos Dez Mandamentos quanto as questões sobre a verdade. Il papa parla della "gerarchia della verità", e dice che il cardine della verità bíblica è la carità di Dio. E dunque la misericórdia costituisce l'ermeneutica delle altri verità e degli stessi comandamenti”. (Cf. KASPER, W., Testimoni della misericórdia. Il mio viaggio com Francesco, p. 11).

${ }^{189}$ FRANCISCO, Angelus, 14 de julho de 2013. Disponível em: $<$ http://w2.vatican.va/content/francesco/pt/angelus/2013/documents/papa-

francesco_angelus_20130714.html>.Acesso em 03 de julho de 2016.

${ }^{190}$ Existe o risco de nos tornarmos espectadores extremamente informados mas desencarnados de tais realidades, ou então de pronunciarmos discursos bonitos que se concluem com soluções verbais e com um desinteresse em relação às problemáticas reais. Muitas palavras, palavras, palavras, mas não fazer nada! Este é um risco. Não é vosso, pois vós trabalhais, e trabalhais bem! Mas é um risco... Quando ouço algumas conversas entre pessoas que conhecem as estatísticas: «Que barbaridade, Padre! Que barbaridade, que barbaridade!». «Mas o que fazes tu para resolver esta barbaridade?». Nada, falo! Mas isto nada resolve! Já ouvimos tantas palavras! É preciso agir, é necessária a vossa obra, o testemunho cristão, é preciso ir ao encontro de quantos sofrem, aproximar-se deles à maneira de Jesus. Imitemos Jesus: Ele sai pelas estradas, sem planificar os pobres, os doentes ou os inválidos com os quais se encontra ao longo do caminho; todavia, detémse com o primeiro que encontra, tornando-se presença que socorre, sinal da proximidade de Deus, que é generosidade, providência e caridade. (CF. FRANCISCO, Discurso as misericórdias da Itália e aos grupos "Fratres" no 30 aniversário da audiência com o Papa João Paulo II, 14 de junho de 2014). 
respeito e com verdade da sua situação, acompanhando-a". ${ }^{191}$ Para além disso, a misericórdia é o que há de essencial no Evangelho:

E o essencial, segundo o Evangelho, é a misericórdia. O essencial do Evangelho é a misericórdia. Deus enviou o seu Filho, Deus fez-se homem para nos salvar, ou seja, para nos dar a sua misericórdia. (...) O cristão deve ser necessariamente misericordioso, porque este é o centro do Evangelho. ${ }^{192}$

A caridade misericordiosa se ramifica desde dentro em atos de solidariedade, fraternidade, partilhando, compartilhando e acolhendo o irmão que sofre. ${ }^{193}$ Assim sendo, nessa abertura ao sofrimento do outro, o homem se esquece de si, abandonando o seu eu enclausurado. ${ }^{194}$ Desta forma, a misericórdia e a alteridade levam ao encontro com o outro, estabelecendo proximidade e vínculos afetuosos e alegres.

Devemos nos deixar envolver pela dor do outro em um testemunho de alteridade para podermos ultrapassar a quase absoluta indiferença que se alastra de forma globalizada, pois o mundo está carente de um suplemento de partilha fraternal e amorosa.

Em seu livro O nome de Deus é Misericórdia, no capítulo intitulado "Misericórdia e Compaixão", Francisco esclarece que ao falarmos em misericórdia nos referimos a um atributo divino, sendo a compaixão um referencial mais humano. ${ }^{195}$

Francisco insiste no tema da misericórdia por ver que há uma crise de fé ${ }^{196}$ que conduz a uma falsa visão do homem e da sociedade e que o leva a não

${ }^{191}$ FRANCISCO, Discurso aos párocos da Diocese de Roma, 06 de março de 2014. Disponível em: $\quad<$ https://w2.vatican.va/content/francesco/pt/speeches/2014/march/documents/papafrancesco_20140306_clero-diocesi-roma.html>. Acesso em 22 de abril de 2015.

192 FRANCISCO, Audiência Geral, 10 de setembro de 2014. Disponível em: <http://w2.vatican.va/content/francesco/pt/audiences/2014/documents/papa-

francesco_20140910_udienza-generale.html>. Acesso em 2 de junho de 2016.

193 Francisco chama os homens à partilha, a uma revisão comportamental, a uma tomada de consciência. Em janeiro de 2014, na Festa do Batismo do Senhor Francisco já proclama o tempo da misericórdia e pergunta: "Não vos parece que, neste nosso tempo, há necessidade de um suplemento de partilha fraternal e amorosa? Não vos parece que todos nós precisamos de um suplemento de caridade? Não daquela que se contenta com a ajuda extemporânea, que não compromete, que não põe em jogo, mas daquela caridade que compartilha, que assume as dificuldades e o sofrimento do irmão".(Cf. FRANCISCO, Jesus sempre nos espera, p. 56).

194 Ibid., p. 45. Remetendo-se a autorreferencialidade Francisco diz que graças ao amor de Deus o homem é resgatado de sua consciência isolada e de sua autorreferencialidade. (Cf. EG 8).

${ }^{195}$ FRANCISCO, O nome de Deus é misericórdia, p. 129.

196 É urgente recuperar o caráter de luz que é próprio da fé, pois, quando a sua chama se apaga, todas as outras luzes acabam também por perder o seu vigor. De fato, a luz da fé possui um caráter singular, sendo capaz de iluminar toda a existência do homem. Ora, para que uma luz seja tão 
acreditar na misericórdia de Deus. Não se deve ter medo, diz Francisco, pois a misericórdia "é um amor que nos alcança e envolve de tal maneira que se antecipa a nós mesmos, permitindo-nos reconhecer a sua face na dos irmãos". ${ }^{197}$ Além do mais, a "misericórdia significa antes de tudo curar as feridas". 198

A proposta de Francisco é de que o homem seja como o Bom Samaritano e se ocupe do irmão que sofre, de modo que o egoísmo se transforme em dom de si mesmo, e a vingança se transforme em perdão; que a cultura do egoísmo seja enterrada, ressurgindo assim a cultura da solidariedade e que em lugar do individualismo que se fecha a alteridade, o outro seja visto de fato como um irmão ${ }^{199}$, uma vez que: "la vida cristiana no es una vida autorreferencial" sino que «sale de sí misma para darse a los demás: es un don, es amor, y el amor no vuelve sobre sí mismo, no es egoísta: ¡se da!» 200

O melhor testemunho da misericórdia segundo Francisco são gestos concretos de amor, pois "através destes gestos simples e vigorosos, mesmo se por vezes invisíveis, podemos visitar aqueles que passam necessidade, levando a ternura e a consolação de Deus". ${ }^{201}$

Cada doença pode encontrar na misericórdia de Deus um auxílio eficaz. Com efeito, a sua misericórdia não se detém à distância: quer vir ao encontro de todas as pobrezas e libertar de tantas formas de escravidão que afligem o nosso mundo.

poderosa, não pode brotar de nós mesmos; tem de vir de uma fonte mais originária, deve provir , em última análise, de Deus. A fé nasce do encontro com o Deus vivo, que nos chama e revela o seu amor: um amor que nós precede e sobre o qual podemos nos apoiar para construir solidamente a vida. Transformados por este amor, recebemos olhos novos, experimentamos que há nele uma grande promessa de plenitude e se nos abre a visão do futuro. (Cf. LF 4).

197 A propósito da fé Francisco diz que uma fé que não é capaz de misericórdia não é fé. (Cf. FRANCISCO, Vigília de oração por ocasião do Jubileu da Divina Misericórdia, 02 de abril de 2016). Disponível em: <https://w2.vatican.va/content/francesco/pt/speeches/2016/april/documents/papafrancesco_20160402_veglia-preghiera.html>. Acesso em 01 de julho de 2016.

${ }^{198}$ FRANCISCO, Discurso aos párocos da Diocese de Roma, 6 de março de 2014. Disponível em: <http://w2.vatican.va/content/francesco/pt/speeches/2014/march/documents/papafrancesco_20140306_clero-diocesi-roma.html>. Acesso em 03 de julho de 2016.

${ }^{199}$ FRANCISCO, JMJ Visita a comunidade de Varginha, 25 de julho de 2013. Disponível em: <http://w2.vatican.va/content/francesco/pt/speeches/2013/july/documents/papafrancesco_20130725_gmg-comunita-varginha.html>. Acesso em 2 de julho de 2015.

${ }^{200}$ Cf. FRANCISCO, Misas matutinas en la capilla de la domus Sanctae Marthae. Esos cristianos necios, 11 de setembro de 2014. Disponível em: <http://w2.vatican.va/content/francesco/es/cotidie/2014/documents/papafrancesco_20140911_cristianos-necios.html>. Acesso em 10 de agosto de 2015. 201 FRANCISCO, Jubileu Extraordinário da Misericórdia. Jubileu da Divina Misericórdia. Homilia, 03 de abril de 2016. Disponível em: <https://w2.vatican.va/content/francesco/pt/homilies/2016/documents/papafrancesco_20160403_omelia-giubileo-divina-misericordia.pdf>. Acesso em 01 de julho de 2016. 
Quer alcançar as feridas de cada um, para medicá-las. Ser apóstolos de misericórdia significa tocar e acariciar as suas chagas, presentes hoje também no corpo e na alma de muitos dos seus irmãos e irmãs (...). O Evangelho da misericórdia, que se deve anunciar e escrever na vida, procura pessoas com o coração paciente e aberto, «bons samaritanos» que conhecem a compaixão e o silêncio perante o mistério do irmão e da irmã; pede servos generosos e alegres, que amam gratuitamente sem nada pretender em troca. ${ }^{202}$

Uma vez que, por definição, "misericórdia significa abrir o coração ao miserável”, Francisco vai trabalhar o tema do coração misericordioso na perspectiva da «sapientia cordis», da sabedoria do coração ${ }^{203}$ de forma a defini-la e demonstrar que:

Esta sabedoria não é um conhecimento teórico, abstracto, fruto de raciocínios. (...). Trata-se, por conseguinte, de uma disposição infundida pelo Espírito Santo na mente e no coração de quem sabe abrir-se ao sofrimento dos irmãos e neles reconhece a imagem de Deus. ${ }^{204}$

Servir ao irmão, estar com o irmão, sair de si ao encontro do irmão, não julgar o irmão, são frutos da sapientia cordis, radicada em uma humanidade que compreende as realidades da vida, as debilidades humanas, que se preocupa e que acolhe.

Mesmo quando a doença, a solidão e a incapacidade levam a melhor sobre a nossa vida de doação, a experiência do sofrimento pode tornar-se lugar privilegiado da transmissão da graça e fonte para adquirir e fortalecer a sapientia cordis. (...) Também as pessoas imersas no mistério do sofrimento e da dor, se acolhido na fé, podem tornar-se testemunhas vivas duma fé que permite abraçar o próprio sofrimento, ainda que o homem não seja capaz, pela própria inteligência, de o compreender até ao fundo ${ }^{205}$.

\subsection{1}

\section{Sabedoria do coração é servir o irmão.}

Em Francisco servir ao irmão é comparável a uma liturgia existencial em que o homem se une a Deus em um ato de amor. Não servir é profanar o templo de Deus e defenestrar o irmão é não acolher ao próprio Deus, pois ver o irmão é ver a Deus.

\footnotetext{
${ }^{202}$ Ibid

${ }^{203}$ FRANCISCO, Mensagem para o XXIII dia Mundial do Doente 2015, 03 de dezembro de 2014. Disponível em: <http://w2.vatican.va/content/francesco/pt/messages/sick/documents/papafrancesco_20141203_giornata-malato.html >. Acesso em m29 de junho de 2016.

${ }^{204}$ Ibid.

${ }^{205}$ Ibid.
} 
O Espírito Santo fala-nos, hoje, também através das palavras de São Paulo: «Sois templo de Deus (...); o templo de Deus é santo, e esse templo sois vós» (1 Cor 3, 16-17). Neste templo que somos nós, celebra-se uma liturgia existencial: a da bondade, do perdão, do serviço; numa palavra, a liturgia do amor. Este nosso templo fica de certo modo profanado, quando descuidamos os deveres para com o próximo: quando no nosso coração encontra lugar o menor dos nossos irmãos, é o próprio Deus que aí encontra lugar; e, quando se deixa fora aquele irmão, é o próprio Deus que não é acolhido. ${ }^{206}$

O serviço prestado ao irmão que sofre é doação fraterna, ancorada na força do Pai. É fazer-se "próximo" para cuidar do outro. "A atitude generosa e cristã para com os doentes é sal da terra e luz do mundo". ${ }^{207}$

Ser cristão comporta servir a dignidade dos irmãos, lutar pela dignidade dos irmãos e viver para a dignificação dos irmãos. Por isso, à vista concreta dos mais frágeis, o cristão é sempre convidado a pôr de lado as suas exigências, expectativas, desejos de onipotência. (...) Este cuidar por amor não se reduz a uma atitude de servilismo; simplesmente põe no centro a questão do irmão: o serviço fixa sempre o rosto do irmão, toca a sua carne, sente a sua proximidade e, em alguns casos, até «padece» com ela e procura a promoção do irmão. ${ }^{208}$

Servir significa ${ }^{209}$ cuidar, de modo especial, da fragilidade do irmão. Em

família, cuidar dos mais vulneráveis, das crianças, dos idosos, dos doentes, das pessoas com deficiência; na sociedade, é cuidar desses mesmos irmãos e para além deles e cuidar do povo, dos rostos sofredores, indefesos e angustiados, que Jesus convida a amar. Servir ao irmão mais frágil e necessitado é um dos frutos da

\footnotetext{
${ }^{206}$ FRANCISCO, Santa Missa com os novos cardeais, 23 de fevereiro de 2014. Disponível em: $<$ http://w2.vatican.va/content/francesco/pt/homilies/2014/documents/papafrancesco_20140223_omelia-nuovi-cardinali.html>. Acesso em 03 de julho de 2016.

207 Cf. FRANCISCO, Angelus, 09 de fevereiro de 2014. Disponível em: <http://w2.vatican.va/content/francesco/pt/angelus/2014/documents/papafrancesco_angelus_20140209.html>. Acesso em 04 de julho de 2016.

${ }^{208}$ FRANCISCO, Viagem Apostólica a Cuba, 20 de setembro de 2015. Disponível em: <https://w2.vatican.va/content/francesco/pt/homilies/2015/documents/papafrancesco_20150920_cuba-omelia-la-habana.html>. Acesso em 01 de julho de 2016.

${ }^{209}$ Servir. Que significa? Servir significa acolher a pessoa que chega, com atenção; significa inclinar-se sobre quem é necessitado e estender-lhe a mão, sem cálculos, sem receio, com ternura e compreensão. (...). Servir significa trabalhar ao lado dos mais necessitados, estabelecer com eles antes de tudo relações humanas, de proximidade, vínculos de solidariedade. Solidariedade, esta palavra que assusta o mundo desenvolvido. Procuram não dizê-la. Solidariedade para eles é quase um palavrão. Mas é a nossa palavra! Servir significa reconhecer e acolher os pedidos de justiça, de esperança, e procurar juntos caminhos, percursos concretos de libertação. Acompanhar as pessoas na busca do trabalho e na inserção social (...). Também actividades culturais, a fim de contribuir para fazer crescer uma cultura do acolhimento, uma cultura do encontro e da solidariedade, a partir da tutela dos direitos humanos. (...). Servir, acompanhar significa também defender, significa pôrse do lado de quem é mais débil. (Cf. FRANCISCO, Visita ao "Centro Astalli" de Roma para a assistência aos refugiados, 10 de setembro de 2013. Disponível em: <https://w2.vatican.va/content/francesco/pt/speeches/2013/september/documents/papafrancesco_20130910_centro-astalli.html>. Acesso em 03 de julho de 2016.
} 
verdadeira humanidade. Servir é agir na dimensão do bem, sem se questionar sobre o mérito do irmão; é fazer o bem pelo bem.

\subsection{2 \\ Sabedoria do coração é estar com o irmão}

A sabedoria do coração misericordioso se torna concreta quando se está próximo de quem é doente, de quem está na prisão, de quem está abandonado e morre sozinho. Francisco ressalta que a força da misericórdia supera qualquer muro, qualquer barreira, muda o coração e a vida, e tem o poder de regenerar uma pessoa e permitir que ela se insira de maneira nova na sociedade. ${ }^{210}$

Quanto ao tempo dedicado ao doente, esse é um tempo santo, fruto de um acompanhamento às vezes silencioso. Os irmãos que sofrem se sentem mais amados e confortados graças à proximidade e ao afeto que recebem de sua família e de seus cuidadores. "E, ao invés, que grande mentira se esconde por trás de certas expressões que insistem muito sobre a «qualidade da vida» para fazer crer que as vidas gravemente afectadas pela doença não mereceriam ser vividas"! $!^{211}$

O Evangelho está cheio de episódios que apresentam a misericórdia de Jesus, a gratuidade do seu amor por quantos sofrem, pelos mais frágeis. Das narrações evangélicas podemos sentir a proximidade, a bondade e a ternura com as quais Jesus acompanhava as pessoas sofredoras e as consolava, dando-lhes alívio e muitas vezes a cura. A exemplo do nosso Mestre, também nós somos chamados a tornar-nos próximos, a compartilhar a condição das pessoas com as quais nos encontramos. É necessário que as nossas palavras, os nossos gestos e as nossas atitudes manifestem a solidariedade, a vontade de não permanecermos alheios à dor dos outros, e isto com entusiasmo fraternal e sem cairmos em qualquer forma de paternalismo. ${ }^{212}$

\subsection{3}

\section{Sabedoria do coração é sair de si ao encontro do irmão}

\footnotetext{
210 FRANCISCO, Audiência Geral, 10 de setembro de 2014. Disponível em: <http://w2.vatican.va/content/francesco/pt/audiences/2014/documents/papafrancesco_20140910_udienza-generale.html>. Acesso em 10 de julho de 2016.

${ }^{211}$ FRANCISCO, Mensagem para o XXIII dia Mundial do Doente 2015, 03 de dezembro de 2014.

212 FRANCISCO, Discurso as Misericórdias da Itália e aos grupos $\langle\langle$ Fratres $\rangle\rangle$ no $30^{\circ}$ aniversário da audiência com o Papa João Paulo II, 14 de junho de 2014.
} 
Atuar com o coração é fruto de uma permissão e de uma decisão interior que não automatiza o agir; é a escolha de aceitar e acolher um dom ${ }^{213}$, surpreender-se com a sua beleza e fazê-lo resplandecer na sociedade. ${ }^{214}$ Essa opção acontece a partir do momento em que o homem ouve o "chamado" de Deus e o segue, despojando-se de si e centrando a sua existência no Senhor. "Cada cristão, está sempre em saída de si mesmo. O epicentro do seu coração está fora dele: é um descentrado de si mesmo, porque centrado apenas em Jesus. Não é atraído pelo seu eu, mas pelo Tu de Deus e pelo "nós" dos homens". ${ }^{215}$

O despojamento de si põe o homem em caminho de adoração e serviço ao Senhor e para o Senhor, e se concretiza no serviço ao irmão, de tal forma que nada conserve para si.

Este "êxodo" de nós mesmos é pôr-nos num caminho de adoração e serviço. Um êxodo que nos leva por um caminho de adoração ao Senhor e de serviço a Ele nos irmãos e nas irmãs. Adorar e servir: duas atitudes que não se podem separar, mas devem caminhar sempre juntas. Adorar o Senhor e servir os outros, nada conservando para si mesmo. ${ }^{216}$

O despojar-se de tudo por adoração ao Senhor tem como consequência a prática concreta da misericórdia que está sedimentada no amor a Deus,

\footnotetext{
${ }^{213}$ Esse dom envia o homem para junto dos mais pobres e marginalizados na qualidade de consolador e faz daquele que manifesta esse dom ao próximo um instrumento das "carícias de Deus". Assim diz Francisco: "Caros amigos, também vós vos sentis enviados para junto das irmãs e dos irmãos mais pobres, frágeis e marginalizados. E agis assim enquanto baptizados, sentindo isto como uma tarefa que vos compete como fiéis leigos. E não como um ministério extraordinário ou fortuito, mas fundamental, no qual a Igreja se identifica, praticando-o quotidianamente. Cada dia apresentam-se situações que nos interpelam. Todos os dias cada um de nós é chamado a ser consolador, a fazer-se instrumento humilde, mas, generoso da Providência de Deus e da sua bondade misericordiosa, do seu amor que compreende e se compadece, da sua consolação que anima e encoraja. Cada dia todos nós somos chamados a ser "carícia de Deus" para quantos esqueceram os primeiros afagos e que, talvez, nunca receberam na sua vida uma carícia!" (Cf. FRANCISCO, Discurso aos sócios do círculo de São Pedro. 31 de outubro de 2013. Disponível em:<http://w2.vatican.va/content/francesco/pt/speeches/2013/october/documents/papafrancesco_20131031_circolo-san-pietro.html>. Acesso em 29 de junho de 2016.

${ }^{214}$ FRANCISCO, Discurso à Associação Nacional das famílias numerosas, 28 de dezembro de 2014. Disponível em: <http://w2.vatican.va/content/francesco/pt/speeches/2014/december/documents/papafrancesco_20141228_famiglie-numerose.html>. Acesso em 04 de julho de 2016.

${ }^{215}$ FRANCISCO, Jubileu Extraordinário da Misericórdia. Jubileu dos Sacerdotes, 03 de junho de 2016. Disponível em: <http://w2.vatican.va/content/francesco/pt/homilies/2016/documents/papafrancesco_20160603_omelia-giubileo-sacerdoti.html>. Acesso em 02 de julho de 2016.

216 FRANCISCO, Discurso às religiosas participantes na Assembleia Plenária da União Internacional das Superioras-gerais, 08 de maio de 2013. Disponível em: <http://w2.vatican.va/content/francesco/pt/speeches/2013/may/documents/papafrancesco_20130508_uisg.html>. Acesso em 04 de julho de 2016.
} 
capacitando o homem a amar e a servir ao próximo, mormente àquelas periferias existenciais $^{217}$, vítimas de uma cultura excludente.

Francisco esclarece que a dinâmica do êxodo e do dom consiste em que o homem saia de si mesmo, caminhe e semeie sempre de novo, sempre mais além $^{218}$, doando-se ao irmão na gratuidade e elucida que na sapientia cordis, que é dom de Deus, torna-se imprescindível a saída de si próprio para o irmão, em razão de que o nosso agir tem uma dimensão transcendente e a maneira como agimos para com o irmão vem delimitada nos Evangelhos. Portanto, há uma absoluta prioridade da "saída de si próprio para o irmão", porque o êxodo de si tem como fundamento a Palavra. ${ }^{219}$

Francisco afirma que o êxodo de si faz o homem abandonar a própria comodidade e sair em direção às periferias existenciais e geográficas. Tal atitude está de acordo com o método que Jesus ensinou e cujo conteúdo expressa a misericórdia do Pai. Esse método vem delineado por Francisco da seguinte forma:

Cada cristão e cada comunidade há de discernir qual é o caminho que o Senhor the pede, mas todos somos convidados a aceitar esta chamada: sair da própria comodidade e ter a coragem de alcançar todas as periferias que precisam da luz do Evangelho. ${ }^{220}$

Por outro lado, o êxodo de si para o irmão é "o sinal mais claro para se discernir sobre o caminho de crescimento espiritual em resposta à doação absolutamente gratuita de Deus". ${ }^{221}$ Sair de si em direção ao irmão doente, por pura gratuidade, é um ato de grande ternura e de valor especial.

\footnotetext{
217 Antes de tudo, o compromisso a deixar-vos guiar pela perspectiva de «sair», de se pôr a caminho rumo às várias regiões de confim, tanto geográficas como existenciais, com uma atenção preferencial pelos pobres e pelas diversas formas de exclusão, que são numerosas. (Cf. FRANCISCO, Discurso às participantes no Capítulo Geral das filhas de Maria Auxiliadora, 08 de novembro de 2014.2 Disponível em: $<$ https://w2.vatican.va/content/francesco/pt/speeches/2014/november/documents/papafrancesco_20141108_figlie-maria-ausiliatrice.pdf >. Acesso em 01 de julho de 2016. ${ }^{218}$ Cf. EG 21.

219 “A Palavra de Deus ensina que, no irmão, está o prolongamento permanente da Encarnação para cada um de nós: «Sempre que fizestes isto a um destes meus irmãos mais pequeninos, a Mim mesmo o fizestes» $(M t 25,40)$. O que fizermos aos outros, tem uma dimensão transcendente: «Com a medida com que medirdes, assim sereis medidos» $(M t 7,2)$; e corresponde à misericórdia divina para connosco: «Sede misericordiosos como o vosso Pai é misericordioso. Não julgueis e não sereis julgados; não condeneis, e não sereis condenados; perdoai, e sereis perdoados. Dai e ser-vos-á dado (...). A medida que usardes com os outros será usada convosco» $(L c 6,36-38)$. Nestes textos, exprime-se a absoluta prioridade da «saída de si próprio para o irmão», como um dos dois mandamentos principais que fundamentam toda a norma moral". (Cf. EG 179).

${ }^{220}$ FRANCISCO, Jesus sempre nos espera, pp. 72-73. Ver também EG 20.

${ }^{221}$ Cf. EG 179.
} 


\subsection{4}

\section{Sabedoria do coração é ser solidário com o irmão sem o julgar}

Francisco dissocia julgar o próximo de ser misericordioso, pois a verdadeira caridade partilha e não julga e não tem a pretensão de converter o outro. Nisso consiste a misericórdia e para isso é necessário conhecer a si mesmo e alargar o coração: $:^{222}$

Quem sou eu para julgar os outros? É a pergunta que devemos fazer a nós mesmos para dar espaço à misericórdia, a atitude justa para construir a paz entre as pessoas, as nações e dentro de nós. Para sermos mulheres e homens misericordiosos é necessário reconhecer, em primeiro lugar, que somos pecadores e depois alargar o coração até esquecer as ofensas recebidas. ${ }^{223}$

\section{4}

\section{A Igreja da misericórdia}

O caminho da misericórdia está para além de falar sobre a pobreza, mas se radica em ter uma atitude concreta em relação a ela. Essa atitude é o pedido que Francisco faz a sua Igreja: a Igreja que sai e vai em direção a esses pobres, infelizes, doentes, enfim, a essas pessoas e a esses lugares aos quais Francisco denomina como "periferias existenciais" e "periferias geográficas".

A arquitrave que suporta a vida da Igreja é a misericórdia. Toda a sua acção pastoral deveria estar envolvida pela ternura com que se dirige aos crentes; no anúncio e testemunho que oferece ao mundo, nada pode ser desprovido de misericórdia. A credibilidade da Igreja passa pela estrada do amor misericordioso e compassivo. A Igreja «vive um desejo inexaurível de oferecer misericórdia ». Talvez, demasiado tempo, nos tenhamos esquecido de apontar e viver o caminho da misericórdia. ${ }^{224}$

Desde o seu episcopado em Buenos Aires, Francisco deu-se conta de que as "periferias" existenciais não são somente lugares, são pessoas, cabendo à Igreja

\footnotetext{
${ }^{222}$ Quem sou eu para julgar isto? Quem sou eu para falar disto? Quem sou eu, que fiz as mesmas coisas ou até pior?». Com efeito, «se tiveres o coração largo, grande, podes receber mais!». E um «coração grande não se intromete na vida dos outros, não condena, mas perdoa e esquece», exactamente como "Deus esqueceu e perdoou os meus pecados". (Cf. FRANCISCO, Cristãos disfarçados, 20 de março de 2014. Disponível em: <http://w2.vatican.va/content/francesco/pt/cotidie/2014/documents/papafrancesco_20140320_meditazioni-41.html>. Acesso em 1 de julho de 2016. ${ }^{223}$ Ibid.

${ }^{224}$ MV 10.
} 
por missão, sair rumo às periferias ${ }^{225}$ do mundo e da existência. ${ }^{226} \mathrm{E}$ em linha de continuidade com seu pensamento como arcebispo em Buenos Aires, em sua primeira expressiva viagem em razão da XXVIII Jornada Mundial da Juventude em 2013, Francisco conclamou a Igreja a sair ${ }^{227}$ em missão rumo às periferias existenciais $^{228}$, levando em consideração os mais esquecidos.

A missão da Igreja em saída em direção às periferias existenciais se fundamenta na fidelidade ao Evangelho, para que chegue às periferias uma palavra de esperança e para que a face misericordiosa de Deus resplandeça por meio da prática solidária da Igreja para com os nossos irmãos mais vulneráveis. ${ }^{229}$

${ }^{225}$ É necessário sair da própria comunidade e ter a audácia de chegar às periferias existenciais que têm necessidade de sentir a proximidade de Deus. Ele não abandona ninguém e manifesta sempre a sua ternura e a sua misericórdia inesgotável; por conseguinte, é isto que é preciso levar a todas as pessoas. (Cf. FRANCISCO, Mensagem de vídeo aos participantes na peregrinação-encontro no Santuário dedicado a Nossa Senhora de Guadalupe na cidade do México, 16 de novembro de 2013). Disponível em: <http://w2.vatican.va/content/francesco/pt/messages/pontmessages/2013/documents/papa-francesco_20131116_videomessaggio-guadalupe.html>. Acesso em 04 de julho de 2016.

${ }^{226}$ Cf. FRANCISCO, Mensagem por ocasião do XXXV meeting para a amizade entre os povos, 23 de agosto de 2014. Disponível em: <http://w2.vatican.va/content/francesco/pt/messages/pontmessages/2014/documents/papa-francesco_20140823_messaggio-meeting-amiciziapopoli.html>.Acesso em 03 de julho de 2016.

227 A Igreja «em saída» é a comunidade de discípulos missionários que «primeireiam», que se envolvem, que acompanham, que frutificam e festejam. Primeireiam - desculpai o neologismo -, tomam a iniciativa! A comunidade missionária experimenta que o Senhor tomou a iniciativa, precedeu-a no amor (cf. $1 \mathrm{Jo} 4,10$ ), e, por isso, ela sabe ir à frente, sabe tomar a iniciativa sem medo, ir ao encontro, procurar os afastados e chegar às encruzilhadas dos caminhos para convidar os excluídos. Vive um desejo inexaurível de oferecer misericórdia, fruto de ter experimentado a misericórdia infinita do Pai e a sua força difusiva. Ousemos um pouco mais no tomar a iniciativa! Como consequência, a Igreja sabe "envolver-se". (Cf. EG 24).

${ }^{228}$ Anunciar até às periferias. (...). Mas quero sublinhá-lo, também porque se trata de um elemento que vivi muito quando estava em Buenos Aires. (...). A importância de sair para ir ao encontro do próximo, nas periferias que são lugares, mas são sobretudo pessoas em situações de vida especial. É o caso da minha Diocese precedente, a de Buenos Aires. Uma periferia que me causava muito sofrimento, era quando eu encontrava nas famílias da classe média crianças que não sabiam fazer o Sinal da Cruz. Mas esta é uma periferia! E eu pergunto-vos: aqui, nesta diocese, existem crianças que não sabem fazer o Sinal da Cruz? Pensai sobre isto. Estas são autênticas periferias existenciais, onde não há lugar para Deus. Num primeiro sentido, as periferias desta Diocese, por exemplo, são as áreas da Diocese que correm o risco de ser marginalizadas, permanecendo fora das faixas de luz dos reflectores. Mas são também pessoas, realidades humanas deveras marginalizadas, desprezadas. São pessoas que talvez se encontrem fisicamente próximas do «centro», mas que sob o ponto de vista espiritual estão distantes. Não tenhais medo de sair e ir ao encontro destas pessoas, de tais situações. Não vos deixeis bloquear por preconceitos, por hábitos, por inflexibilidades mentais ou pastorais, pelo famoso "sempre fizemos assim!". (Cf. FRANCISCO, Encontro com o Clero, os consagrados e os membros dos pastorais, 04 de outubro de 2013. Disponível em: <http://w2.vatican.va/content/francesco/pt/speeches/2013/october/documents/papafrancesco_20131004_clero-assisi.html>. Acesso em 29 de junho de 2016.

${ }^{229}$ Em fidelidade ao Evangelho e em resposta às necessidades urgentes do presente, somos chamados a ir ao encontro daqueles que se encontram nas periferias existenciais das nossas sociedades e a manifestar uma solidariedade especial para com os nossos irmãos e irmãs mais 
Toda a sua acção pastoral deve estar envolvida pela ternura com que se dirige aos crentes. O anúncio e o testemunho que oferece ao mundo, de nenhuma forma, pode ser desprovido de misericórdia.

As diretrizes dessa Igreja tomam forma na Exortação Apostólica Evangelii Gaudium onde Francisco passa a retratá-la. Uma Igreja que faz uma opção pelos pobres, inspirada na preferência divina, pois é a eles que Deus manifesta a Sua misericórdia, antes de mais nada. ${ }^{230}$

A Igreja é a casa do Pai que está sempre de portas abertas ${ }^{231}$ e cuja misericórdia opera como via de mão dupla: a Igreja cujas portas abertas a permite sair de si mesma; a Igreja cujas portas abertas é sinal de acolhida misericordiosa e de inclusão para aquele que está de fora. Uma Igreja que não deve ser fechada em si mesma, não devendo ser autorreferencial ${ }^{232}$ " e que seja o lugar "da misericórdia gratuita, onde todos possam sentir-se acolhidos, amados, perdoados e animados a viverem segundo a vida boa do Evangelho", ${ }^{233}$ pois o caminho da Igreja é o de não condenar eternamente ninguém; é o de derramar a misericórdia de Deus sobre todas as pessoas que a pedem com coração sincero.

É possível ver a íntima relação que há entre a misericórdia divina paternal, maternal ${ }^{234}$ e familiar, e a Igreja misericordiosa que sai na direção das periferias

vulneráveis: os pobres, os portadores de deficiência, os nascituros, os enfermos, os migrantes, os refugiados, os idosos e os jovens desempregados" (Cf. FRANCISCO, Mensagem ao cardeal Kurt Koch por ocasião da $10^{a}$ Assembleia Geral do Conselho Ecuménico das Igrejas, 04 de outubro de 2013. Disponível em: <http://w2.vatican.va/content/francesco/pt/messages/pontmessages/2013/documents/papa-francesco_20131004_world-council-churches.html>. Acesso em 30 de junho de 2016.

${ }^{230}$ Cf. EG 198.

${ }^{231}$ A Igreja é chamada a ser sempre a casa aberta do Pai. Um dos sinais concretos desta abertura é ter, por todo o lado, igrejas com as portas abertas. Assim, se alguém quiser seguir uma moção do Espírito e se aproximar à procura de Deus, não esbarrará com a frieza duma porta fechada (Cf. EG 47).

${ }^{232}$ Francisco assevera que: "fechar-se em si mesmo é provar o veneno amargo da imanência e a humanidade perderá com cada opção egoísta que fizermos. (Cf. EG 87).

${ }^{233}$ EG 114.

${ }^{234}$ Em Amoris Laetitia Francisco vai dizer que a "Mãe Igreja" é chamada a levar a misericórdia de Deus aos que vivem situações difíceis: "Nas situações difíceis em que vivem as pessoas mais necessitadas, a Igreja deve pôr um cuidado especial em compreender, consolar e integrar, evitando impor lhes um conjunto de normas, tendo como resultado fazê-las sentir-se julgadas e abandonadas precisamente por aquela Mãe que é chamada a levar-lhes a misericórdia de Deus. (Cf. AL 49). 
existenciais, como um pai que espera pelo filho, como o pai do filho pródigo e a mãe de coração aberto. ${ }^{235}$

Francisco convoca a Igreja e, portanto, convoca os cristãos que saiam e se deixem encontrar pelo Senhor. O encontro com Ele deve levar ao encontro dos outros, dos mais necessitados, dos pobres; ${ }^{236}$ a Igreja em saída deve levar o Evangelho a todos, ainda que se acidente, pois Francisco prefere "uma Igreja acidentada, mas não doente. ${ }^{237}$

O Evangelho é para todos, e não apenas para alguns. Não é apenas para aqueles que parecem a nós mais próximos, mais abertos, mais acolhedores. É para todas as pessoas. Não tenham medo de ir e levar Cristo para todos os ambientes, até as periferias existenciais incluindo quem parece mais distante, mais indiferente. $\mathrm{O}$ Senhor procura a todos, quer que todos sintam o calor da sua misericórdia e do seu amor. $^{238}$

A Igreja deve sair em direção a todos os homens com o intuito de conscientizá-los da necessidade de um diálogo individual com Deus e também no sentido de confirmar que nas periferias a misericórdia divina se manifesta.

$\mathrm{Na}$ visão de Francisco vislumbra-se uma Igreja cuja atividade pastoral seja orientada pelo impulso missionário, não cabendo a exclusão de quem quer que seja. Uma Igreja alegre, que se desloque até às periferias geográficas e existenciais para levar a todos o amor, a misericórdia de Deus. Uma Igreja que

${ }^{235}$ Uma mãe de coração aberto: "A Igreja «em saída» é uma Igreja com as portas abertas. Sair em direç̧ão aos outros para chegar às periferias humanas não significa correr pelo mundo sem direcção nem sentido. Muitas vezes é melhor diminuir o ritmo, pôr de parte a ansiedade para olhar nos olhos e escutar, ou renunciar às urgências para acompanhar quem ficou caído à beira do caminho. Às vezes, é como o pai do filho pródigo, que continua com as portas abertas para, quando este voltar, poder entrar sem dificuldade". (Cf. EG 46).

${ }^{236}$ Cf. FRANCISCO, Mensagem vídeo por ocasião da abertura do ano da vida consagrada na Basílica de Santa Maria Maior, 29 de novembro de 2014. Disponível em: <http://w2.vatican.va/content/francesco/pt/messages/pont-messages/2014/documents/papa-

francesco_20141129_video-messaggio-vita-consacrata.html>. Acesso em 30 de junho de 2016. Ver EG 20.

${ }^{237}$ Quando um cristão está fechado no seu grupo, na sua paróquia, no seu movimento, está fechado, adoece. Se um cristão sai pelas estradas, vai às periferias pode acontecer-lhe o mesmo que a qualquer pessoa que anda na estrada: um acidente. Quantas vezes vimos acidentes estradais! Mas eu digo-vos: prefiro mil vezes uma Igreja acidentada que uma Igreja doente!(Cf. FRANCISCO, Discurso aos catequistas vindos a Roma em peregrinação por ocasião do Ano da Fée do Congresso Internacional de Catequese, 27 de setembro de 2013. Disponível em: $<$ http://w2.vatican.va/content/francesco/pt/speeches/2013/september/documents/papafrancesco_20130927_pellegrinaggio-catechisti.html >. Acesso em 29 de junho de 2016.

${ }^{238}$ FRANCISCO, Visita apostólica por ocasião da XXVIII jornada mundial da juventude, 28 de julho de 2013. Disponível em: $<$ https://w2.vatican.va/content/francesco/pt/homilies/2013/documents/papafrancesco_20130728_celebrazione-xxviii-gmg.html >. Acesso em 30 de junho de 2016. 
não jogue na cara das pessoas suas fragilidades e feridas e cure com o remédio da misericórdia: ${ }^{239}$

A Igreja não está no mundo para condenar, mas para permitir o encontro com aquele amor visceral que é a misericórdia de Deus. Para que isso aconteça, tenho repetido muitas vezes, é necessário sair. Sair das igrejas e das paróquias, sair e ir procurar as pessoas lá onde elas vivem, onde sofrem, onde esperam. (...) Uma Igreja que redescobre as entranhas maternas da misericórdia e que vai ao encontro de tantos "feridos" necessitados de escuta, compreensão, perdão e amor. ${ }^{240}$

A Igreja em Francisco é um hospital de campanha que socorre os feridos que estão oprimidos, e, assim agindo, anuncia e confirma a misericórdia de Deus, pois essa é sua missão: “a Igreja tem a missão de anunciar a misericórdia de Deus, coração pulsante do Evangelho, que por meio dela deve chegar ao coração e à mente de cada pessoa". ${ }^{241}$

A Igreja deve não só olhar aos feridos com compaixão, mas, também escutá-los. Esse caminho na direção do outro se dá na proximidade e assim o agir misericordioso de Deus se faz presente. O escutar misericordioso e compassivo é o que permite que haja um encontro espiritual e um crescimento expressivo. ${ }^{242}$

\section{5 O Jubileu Extraordinário da Misericórdia}

No ano de 2015 Francisco proclamou o Ano Santo da Misericórdia, o Jubileu Extraordinário da Misericórdia, que teve no Jubileu das Pessoas Enfermas, e das Pessoas com Deficiência, em junho de 2016, um dos seus momentos mais expressivos.

Nesse Jubileu todos são convidados a buscar a misericórdia e o perdão de Deus, e todos são estimulados a praticar a misericórdia com os que sofrem. Portanto, o Ano Santo da Misericórdia" deve ser vivido na prática de obras corporais e espirituais de misericórdia ${ }^{243}$ em relação às quais, Francisco requer que haja uma profunda reflexão.

\footnotetext{
${ }^{239}$ FRANCISCO, O nome de Deus é misericórdia, p. 18.

${ }^{240}$ Ibid., pp 86-87.

${ }^{241}$ MV 12.

${ }^{242}$ Cf. EG 169-171.

${ }^{243}$ As obras de misericórdia são fruto da relação entre Deus e os homens: É da contemplação, de uma forte relação de amizade com o Senhor que nasce em nós a capacidade de viver e de anunciar o amor de Deus, a sua misericórdia, a sua ternura pelo próximo. E inclusive o nosso trabalho com
} 
Na Bula de Proclamação do Jubileu Francisco assim define o mistério da misericórdia divina: "É fonte de alegria, serenidade e paz. É a condição de nossa salvação. Misericórdia é: o ato último e supremo pelo qual Deus vem ao nosso encontro". Quanto à misericórdia humana, Francisco assim a define: "Misericórdia é: a lei fundamental que mora no coração de cada pessoa quando vê com olhos sinceros o irmão que encontra no caminho da vida". ${ }^{244}$ E em relação à Igreja Francisco assim dispõe:

Neste Ano Santo, poderemos fazer a experiência de abrir o coração àqueles que vivem nas mais variadas periferias existenciais, que muitas vezes o mundo contemporâneo cria de forma dramática. Quantas situações de precariedade e sofrimento presentes no mundo actual! Quantas feridas gravadas na carne de muitos que já não têm voz, porque o seu grito foi esmorecendo e se apagou por causa da indiferença dos povos ricos. Neste Jubileu, a Igreja sentir-se-á chamada ainda mais a cuidar destas feridas, aliviá-las com o óleo da consolação, enfaixá-las com a misericórdia e tratá-las com a solidariedade e a atenção devidas. Não nos deixemos cair na indiferença que humilha, na habituação que anestesia o espírito e impede de descobrir a novidade, no cinismo que destrói. Abramos os nossos olhos para ver as misérias do mundo, as feridas de tantos irmãos e irmãs privados da própria dignidade e sintamo-nos desafiados a escutar o seu grito de ajuda. As nossas mãos apertem as suas mãos e estreitemo-los a nós para que sintam o calor da nossa presença, da amizade e da fraternidade. Que o seu grito se torne o nosso e, juntos, possamos romper a barreira de indiferença que frequentemente reina soberana para esconder a hipocrisia e o egoísmo. ${ }^{245}$

A misericórdia de Deus tem um rosto ${ }^{246}$ : Jesus de Nazaré que revela a misericórdia de Deus, com seus gestos, sua palavra e sua pessoa. Jesus, o Filho de Deus feito homem. Sua misericórdia se estende a pessoas com deficiência, pois os Evangelhos atestam que Jesus curou surdos, devolveu a visão aos cegos, fez andar o paralítico, libertou os espiritualmente cativos, e suas ações demonstram a misericórdia que tem pelo homem, ao ponto de entregar sua vida pela nossa salvação, pois Ele é o Bom Pastor, e o Bom Pastor dá a vida pelas suas ovelhas.

No próximo capítulo nos remeteremos ao universo cultural, o qual Francisco capta de forma expressiva. Abordaremos essa característica de Francisco no sentido de demonstrar que o seu Magistério tem o condão de abraçar os desejos

irmão em necessidade, a nossa tarefa de caridade nas obras de misericórdia nos levam ao Senhor, para que nós vejamos precisamente o Senhor no irmão e na irmã necessitados. (Cf. FRANCISCO, Angelus, 21 de julho 2013.2 Disponível em: <http://w2.vatican.va/content/francesco/pt/angelus/2013/documents/papafrancesco_angelus_20130721.html>. Acesso em 30 de junho de 2016.

${ }^{244} \mathrm{MV} 2$.

245 MV 15

${ }^{246}$ MV 1. 
culturais de inclusão, fraternidade e encontro, de modo que se torna porta-voz de vozes menores, as quais amplifica, inter-relaciona e aprofunda. 


\section{4}

\section{A pessoa com deficiência: o encontro com Francisco}

O capítulo anterior teve como objeto a abordagem do tema da misericórdia com vistas a demonstrar que o pontificado de Francisco se empenha em levar às pessoas com deficiência e a todas as periferias existenciais e geográficas a graça da misericórdia divina de forma concreta.

Esse último capítulo tem como objetivo demonstrar duas ideias fundamentais. A primeira é atestar que Francisco é um Papa cujo carisma e popularidade estão na razão direta de sua capacidade de ressonância frente aos desejos do mundo. Em outras palavras o que se quer dizer é que os desejos do mundo, sejam bons ou maus, são captados por Francisco, que os assimila e os converte em um sistema de fácil compreensão ao qual ele denomina "culturas".

No sentido de demonstrar a empatia que Francisco tem com o que o circunda, apresentaremos três autores distintos, que na vida tem ou tiveram convivência expressiva com o sofrimento e com pessoas com deficiência: V. Frankl, O. Byington e J. Vanier. Cada um deles traz para a nossa reflexão seus "encontros" com a dor que se transformaram em amor, ressignificando o sofrimento como algo que, a partir de um encontro amoroso, pode fazer sentido.

A segunda ideia é demonstrar a postura de encontro adotada por Francisco em relação às pessoas com deficiência. Francisco dedica parte de seu Magistério a essas pessoas. Assim agindo, coloca em prática aquilo que é voz forte em seu Pontificado: a "cultura do encontro". Por isso abordaremos em maior profundidade nesse capítulo, o tema que diz respeito à cultura do encontro.

A fim de apresentar essas duas ideias, comporemos o presente capítulo em duas partes. Na primeira parte, na intenção de evidenciar essa capacidade de Francisco em captar os anseios do povo, cotejaremos o pensamento desses três autores, V. Frankl, O. Byington e J. Vanier, com o pensamento de Francisco, demonstrando que esses anseios individuais, se amplificam na voz de Francisco, passando a fazer parte das "culturas" e se sedimentando na "cultura do encontro". Restará demonstrado que aquele que convive com as pessoas com deficiência se torna receptor de amor e por isso o sofrimento passa a ter novo significado, passando a ser visto como algo que, a partir de um encontro amoroso, pode fazer sentido. 
A segunda parte será dedicada a apresentar o encontro entre Francisco e as pessoas com deficiência. Esse encontro acontece por meio de seu Magistério. Francisco dedica a essas pessoas palavras de acolhida e de preocupação em relação a uma cultura que visa segregá-las e descartá-las. Por isso tudo é que ele vai chamá-las a fazer parte da "cultura do encontro" e para esse encontro todos são convidados.

\section{1}

\section{A pessoa com deficiência: recurso de humanidade}

$\mathrm{Na}$ Exortação Apostólica Evangelii Gaudium ${ }^{247}$ Francisco se pronuncia sobre a opção preferencial pelos pobres, identificando-os. Eles são aqueles a quem as culturas econômicas, sociais e culturais excludentes lançam fora. São os que compõem as periferias geográficas e existenciais; são os mais frágeis da terra a quem somos chamados a cuidar: "Esse imperativo de ouvir o clamor dos pobres faz-se carne em nós, quando no mais íntimo de nós mesmos, nos comovemos à vista do sofrimento alheio" 248 , quando nos comovemos à vista do sofrimento das pessoas com deficiência.

Apesar do sofrimento, essas pessoas são recursos de humanidade. É assim que Francisco se refere a elas ao dizer que: "servir com amor e ternura as pessoas que precisam de tanta ajuda faz-nos crescer em humanidade, porque elas são verdadeiros recursos de humanidade". ${ }^{249}$ Em razão disso, ele constantemente clama a sociedade para que cuide da fragilidade dessas pessoas, na tentativa de alavancar uma colaboração conjunta em seu favor e na intenção de que se mostre o amor concreto e fraterno em ato, na acolhida dos menos favorecidos.

Foi precisamente isto que vos ensinou o beato Luigi Novarese, educando os doentes e os deficientes a valorizarem os seus sofrimentos no âmbito de uma acção

\footnotetext{
${ }^{247}$ EG 210-215. No que tange aos economicamente pobres Francisco vem desenvolvendo um discurso que diz não ao dinheiro e ao poder que pisam os que são colocados embaixo, em razão da opressão e do aproveitamento inescrupuloso do homem pelo homem. Mas, a pobreza não se restringe a pobreza econômica como acentua Francisco. Então para além da pobreza econômica os pobres são vistos como insignificantes, aquele que é considerado como uma "não pessoa", alguém a quem não se reconhece a plenitude de seus direitos na condição de ser humano.

${ }^{248}$ EG 193.

${ }^{249}$ FRANCISCO, Encontro com as crianças com deficiências e os doentes do Instituto Seráfico. 04 de outubro de 2013. Disponível em: <https://w2.vatican.va/content/francesco/pt/speeches/2013/october/documents/papafrancesco_20131004_bambini-assisi.html>. Acesso em 28 de maio de 2015.
} 
apostólica levada em frente com fé e amor aos outros. Ele dizia sempre: "Os doentes devem sentir-se autores do próprio apostolado". Uma pessoa doente, deficiente, pode tornar-se apoio e luz para os outros sofredores, transformando assim o ambiente no qual vive. Com este carisma vós sois um dom para a Igreja. ${ }^{250}$

Esse chamado finca raízes na própria natureza missionária da Igreja, a qual cabe promover "a caridade efetiva para com o próximo, a compaixão que compreende, assiste e promove". 251

Não se deve fechar as portas ao homem que sofre e renunciar à dimensão social e amorosa do Evangelho, restringindo-se a círculos privados ${ }^{252}$, pois os cristãos são chamados ao amor como verificaremos a seguir.

\subsection{1 \\ Victor Frankl: a busca de sentido para o sofrimento}

Viktor E. Frankl é um autor judeu que sobreviveu aos campos de concentração nazistas. Suas reflexões sobre o sofrimento visto e vivido nos campos de concentração têm por escopo conferir sentido à brutalidade atroz: "Se é que a vida tem sentido, também o sofrimento necessariamente o terá. Afinal de contas, o sofrimento faz parte da vida, de alguma forma, do mesmo modo que o destino e a morte". ${ }^{253}$

O sentido da vida em Frankl ${ }^{254}$ é alcançado levando-se em conta a relação vida e morte, na qual o sofrimento dá razão à descoberta do amor, que não é presença física e sim diálogo espiritual intenso, gratificante, uma contemplação

250 FRANCISCO, Discurso às associações dos Operários Silenciosos da Cruz e Centro de Voluntários do Sofrimento fundadas pelo beato Luigi Novarese, 17 de maio de 2014. Disponível em: $\quad<\mathrm{http}: / /$ w2.vatican.va/content/francesco/pt/speeches/2014/may/documents/papafrancesco_20140517_operai-croce-volontari-sofferenza.html>. Acesso em 23 de junho de 2016.

${ }^{251}$ EG 179.

${ }^{252}$ Cf. EG 88.

${ }^{253}$ FRANKL. E. V., Em busca de sentido. Rio de Janeiro. Vozes, $34^{\circ}$ edição. 2013, p. 90.

${ }^{254}$ Vitor Frankl estabeleceu um método terapêutico que se baseava em procurar o sentido de todas as coisas e no caso do sofrimento, via como ponto fundamental para a sua superação, transcender ao sofrimento, no sentido de ver para além do sofrimento, deslocando-se do eixo em que se está para uma possibilidade que ultrapassa o sofrimento. Significa imaginar um tempo ou um lugar em que a dor há de cessar. Até para os que estão em estado terminal, resta sempre a esperança de uma vida depois da morte onde não haja mais sofrimento. "Il psichiatra Viktor Frankl, il cui método terapêutico si basava essenzialmente nel cercare il senso in tutte le cose, intravedeva come punto fondamentale per superar la sofferenza il trascenderla. Trascendere la sofferenza significa spostare più in là il próprio orizzonte e vedere più in là di essa, il che a sua volta per noi, quali esseri spazio-temporali, significa immaginare um posto o um tempo in cui cessa il dolore. Anche per i malati terminali, per i quali se nella vita terrena no rimane nessuna speranza di guarigione, c'è pur sempre la speranza di uma vita dopo la morte senza più sofferenze. (Cf. SELI, A.; MARTELANC, K., Come incontrare l"altro. La consulenza psico-sociale. Milano: Paoline, 2012, p. 103). 
amorosa que nem mesmo o saber sobre a morte da pessoa amada tem o dom de perturbar. $^{255}$

Frankl traz relatos sobre a vida em uma comunidade que lhe é imposta pelo regime nazista e a partir dessa experiência tomou como necessidade encontrar o sentido para o sofrimento e ver nele uma fonte de realização. Nesse sentido Frankl vai dizer o que se segue:

Quando um homem descobre que seu destino lhe reservou um sofrimento, tem que ver nesse sofrimento também uma tarefa sua, única e original. Mesmo diante do sofrimento, a pessoa precisa conquistar a consciência de que ela é única e exclusiva em todo o cosmo e dentro deste destino sofrido. Ninguém pode assumir dela o destino, e ninguém pode substituir a pessoa no sofrimento. Mas na maneira como ela própria suporta esse sofrimento está também a possibilidade de uma realização única e singular. Para nós, no campo de concentração, nada disso era especulação inútil sobre a vida. (...) O que nos importava já não era mais a pergunta pelo sentido da vida como ela é tantas vezes colocada, ingenuamente, referindo-se a nada mais do que a realização de um alvo qualquer através da nossa produção criativa. $\mathrm{O}$ que nos importava era o objetivo da vida naquela totalidade que inclui também a morte e assim não somente atribui sentido à "vida", mas também ao sofrimento e à morte. Esse era o sentido pelo qual estávamos buscando. ${ }^{256}$

Viktor E. Frankl conclui então pelo sofrimento como fonte de realização, o qual não se pode reprimir, minimizar, nem se iludir a respeito, mas, resgatar; uma incumbência de cujas lágrimas não cabe envergonhar-se.

Uma vez que se nos revelara o sentido do sofrimento, também nos negávamos então a ficar desfazendo ou minimizando o volume do sofrimento que havia no campo de concentração, seja "reprimindo-o" ou iludindo-nos a respeito do mesmo com otimismo barato ou artificial. Para nós ele tinha revelado seu caráter de conquista, aquele caráter de realização que levou Rilke a exclamar: "Wieviel ist aufzuleien" (Quanto sofrimento há por resgatar). Rilke falava de resgatar o sofrimento como outros diriam cumprir uma tarefa. (...). Não precisaria envergonhar-se dessas lágrimas. Eram o penhor de ele ter a maior das coragens - a coragem de sofrer. ${ }^{257}$

\footnotetext{
${ }^{255}$ Assim Frankl se posiciona sobre o amor como essência espiritual: De repente me dou conta: Nem sei se minha esposa ainda vive! Naquele momento fico sabendo, que o amor pouco tem a ver com a existência física de uma pessoa. Ele está ligado a tal ponto à essência espiritual da pessoa amada, a seu "ser assim" (nas palavras dos filósofos) que a sua "presença" e seu "estar-aquicomigo" podem ser reais sem sua existência física em si e independentemente de seu estar com vida.(...). As circunstâncias externas não conseguiam mais interferir no meu amor, na minha lembrança e na contemplação amorosa da imagem espiritual da pessoa amada. Se naquela ocasião tivesse sabido que minha esposa está morta - acho que esse conhecimento não teria perturbado meu enlevo interior naquela contemplação amorosa. $\mathrm{O}$ diálogo espiritual teria sido igualmente intenso e gratificante. Naquele momento, apercebo-me da verdade: "Põe-me como selo sobre o teu coração (...) porque o amor é forte como a morte" (Cantares 8.6). (Cf. FRANKL, E.V., Em busca de sentido, p. 56).

${ }^{256}$ Ibid., pp. 102-103.

${ }^{257}$ Ibid., pp. 103-104.
} 
Frankl se tornou logoterapeuta e nas histórias clínicas, que nos chegam por meio dos seus livros, há um relato em seu livro "Em busca de sentido", que ressalta essa qualidade da pessoa com deficiência como recurso de humanidade em total abertura para amor. Trata-se de uma mãe de dois filhos: um sadio e o outro com deficiência. $\mathrm{O}$ sadio morre aos 11 anos e a mãe fica só, com o filho cadeirante. Não se conformando com seu destino a mãe tenta duplo suicídio e é o filho que a impede. "Mas quando tentou o suicídio, juntamente com ele, foi o filho aleijado que a impediu; ele gostava de viver! Para ele a vida continuava a ter sentido. Por que não se dava o mesmo com sua mãe?"258

Frankl então pede a ela para se imaginar com 80 anos no leito de morte e que faça um retrospecto de sua vida. $\mathrm{O}$ seu testemunho reflete uma vida que teve sentido e que foi justamente poupada e plenificada pelo filho que teve paralisia infantil. "Encarando sua vida passada como se estivesse no leito de morte, ela repentinamente pôde ver um sentido em sua vida, um sentido que incluía até mesmo todos os seus sofrimentos." ${ }^{259} \mathrm{O}$ sentido da vida teve lugar nessa relação que se dá entre o sofrimento e o amor. Vejamos seu relato.

Desejei ter filhos, e esse desejo me foi concedido; um menino morreu, mas o outro, o aleijado, teria sido mandado para uma instituição se eu não tivesse ficado com ele, cuidando dele. Mesmo que ele seja aleijado e completamente dependente, não deixa de ser meu filho. Assim eu fiz com que ele pudesse ter uma vida plena; fiz do meu filho uma pessoa melhor. Quanto a mim, posso encarar tranquila minha vida passada; porque posso dizer que minha vida foi rica em sentido e dei duro para realizá-la; fiz o melhor que pude - dei a meu filho o melhor. Minha vida não foi um fracasso!"260

Ao pensar na vida futura o filho com deficiência se torna o fundamento de sua vida, e a perda do outro filho já se encontra pacificada dentro de seu coração. O sentido da vida foi encontrado e a partir de então o suicído perde o sentido pois, como ela mesma diz, sua vida não foi um fracasso.

\subsection{2}

\section{Olivia Byington: a inclusão e a diversidade}

\footnotetext{
258 Ibid., p. 140.

${ }^{259}$ Ibid., p. 140.

${ }^{260}$ Ibid., p. 141.
} 
O filho da cantora brasileira Olivia Byington nasceu com a Síndrome de Apert. ${ }^{261}$ É a ele que ela dedica seu livro "O que é que ele tem": ao João meu herói ${ }^{262}$, o filho que ao nascer foi sentido como um ser que não se encaixava de modo algum em seus planos, pois não havia porta para ele entrar no seu coração com aquela deformidade: ${ }^{263}$ ele não era o bonito filho sonhado. ${ }^{264}$

Eu estava em construção. Estava diante do mistério da vida. Sem saber, já fazia parte da grande comunidade de pessoas fora do padrão, com chance de arregaçar as mangas e buscar a alegria de novo. Só não sabia que as alegrias viriam e seriam muitas. E que viriam em prestações, entregues por toda a vida que eu ainda tinha pela frente. ${ }^{265}$

Olivia diz que ser mãe de uma criança com deficiência exige humildade e compaixão e que aceitar, compreender e amar um filho imperfeito, foi um processo que pouco a pouco tomou lugar em seu coração. ${ }^{266} \mathrm{O}$ amor de mãe não se importa se o filho é cabeçudo, orelhudo, ama seja lá o que a cegonha entregar. $^{267}$

Uma criança fora do padrão é uma porta e uma oportunidade para se ver algo além. Ela precisa do melhor dos pais. Há quem admita não ter vocação para isso e não queira encarar o fardo. Mas é aí, nessa dor, que a gente tem a chance de se provar. Uma criança com deficiência devolve alegrias em dobro a cada mínima conquista, como uma medalha para os pais que estão ali, despidos de vaidade, ligados à essência da vida. ${ }^{268}$

Olívia conta seu dia a dia com João e suas dificuldades de inclusão ao tentar achar para ele uma escola que o recebesse aos oito anos, não só pela aparência, mas também porque ele não sabia fazer certas distinções entre as coisas, por exemplo: ao pedirem a ele que desenhasse sua família, ele desenhou uma árvore. As escolas achavam comprometedor essa relação desigual, mas, para Olivia, deveria ser um privilégio para as crianças conviverem com alguém que as fizesse

\footnotetext{
${ }^{261}$ Em razão da síndrome o bebê nasceu com uma cabeça gigante, olhos saltados, sem dedos nas mãos. (Cf. BYINGTON O., O que é que ele tem. Rio de Janeiro: Objetiva, 2016, EbookKindle, loc 83).

${ }^{262}$ Ibid., loc 7.

${ }^{263}$ Ibid., loc. 88.

${ }^{264}$ Ibid., loc. 83. Mas com o tempo o que nos primeiros dias parecia impossível veio a tona: o amor materno aflorou. (Cf. BYINGTON O., O que é que ele tem, loc 112).

${ }^{265}$ Ibid., loc. 37.

${ }^{266}$ Cf. Ibid., loc. 131.

${ }^{267}$ Ibid., loc. 385.

${ }^{268}$ Ibid., loc. 178.
} 
lidar com o fenômeno da superação, e a criança não deficiente ganharia preparo para enfrentar a vida e aprenderia a praticar a tolerância. ${ }^{269}$

A ideia de inclusão é abraçada por Olívia para quem: "Nada é melhor para alguém com deficiência do que o convívio com a sociedade. Nada é melhor para a sociedade do que o convívio com as diferenças". ${ }^{270}$ Para ela, João faz parte de uma minoria que precisa de atenção e, se é a época em que as pessoas lutam pela igualdade, ela também toma esse mesmo rumo escrevendo esse livro sobre seu filho. $^{271}$

Olivia reconhece em João uma implacável vocação para a felicidade, ${ }^{272}$ que faz com que ele seja dono de um enorme coração. Embora reconheça a sua deficiência, olha as pessoas de acordo com outra ótica que está sedimentada no amor. $^{273}$

É possível que João saiba que é diferente, mas não se sabe até que ponto vai seu conhecimento. O que Olívia sabe é que sente orgulho do filho ${ }^{274}$ que é uma boa companhia, pois é parceiro. ${ }^{275}$

Olívia lança esse livro no sentido de ajudar aquelas pessoas que vivem a dificuldade do dia a dia com pessoas com deficiência, pois sente na pele o forte preconceito a que estão expostas. Por isso ela diz que há uma minoria que precisa de atenção e dentre essa minoria as pessoas com deficiência tem seu lugar.

Esse livro fala de uma minoria que precisa de atenção. (...) Algumas pessoas me disseram "tomara que a expectativa de vida dele seja curta". Isso é uma conversa deplorável. Não é muito diferente de pessoas que querem pena de morte, que acham que se matar o bandido você acaba com o mal, e a gente sabe que não é assim. Uma criança que nasce com deficiência vai ter a vida que a gente der a ela, a melhor possível..$^{276}$

\footnotetext{
${ }^{269}$ Ibid., loc. 1065 .

${ }^{270}$ Ibid., loc. 1504.

271 RODRIGUES, A. H., CORONATO, M., Muitos homens correm ao ver um filho com deficiência diz Olivia Byington, 26 de junho de 2016. Época Globo. Disponível em: <http://epoca.globo.com/vida/noticia/2016/06/muitos-homens-correm-ao-ver-um-filho-comdeficiencia-diz-olivia-byington.html>. Acesso em 27 de junho de 2016.

${ }^{272}$ Cf. BYINGTON O., O que é que ele tem, loc. 1849.

${ }^{273}$ Ibid., loc. 1852 ..

${ }^{274}$ Ibid., loc. 1918.

275 Ibid., loc. 2143.

276 RODRIGUES, A. H., CORONATO, M., Muitos homens correm ao ver um filho com deficiência diz Olivia Byington, 26 de junho de 2016.
} 
As dificuldades enfrentadas pela curiosidade popular sobre as questões físicas do filho e também por ser do meio artístico, lugar por excelência onde a imagem tem maior valor, Olívia percebe que envelhecer ou não se enquadrar em padrões de beleza levam as pessoas a uma desenfreada busca por ser o que não se é, na tentativa de dar ao físico características que não lhe são próprias, retirando do ser humano aquilo que para ela é a melhor coisa que ele tem, que é a sua individualidade.

Existe uma falta de aceitação do andar normal da carruagem. As pessoas querem cada vez mais ser Deus. A pessoa não pode envelhecer. Então ela se corta, bota borrachas dentro da cara. Então você depara em sua vida com algo que não tem conserto, com uma pessoa que não vai ser um galã de cinema, não vai se enquadrar em um padrão de beleza. Ele vai ser o que ele é e você vai investir nessa pessoa com deficiência. É uma maneira de atingir a compreensão de todas as coisas. É uma nova leitura da superficialidade, da vontade de padronizar e de que todo mundo seja igual. Aí se tira a coisa mais linda do ser humano que é sua individualidade. Cada indivíduo é do seu jeito, cada indivíduo tem suas características que têm de ser respeitadas e cultivadas. (...) Quando você tem um filho com uma diferença - não precisa ser uma deficiência -, você vai ver que ele vai procurar a turma dele e ser feliz ali. Não se deve forçar nem entortar ele para que se encaixe em determinados padrões. ${ }^{277}$

Ao final Olívia traz para o leitor sua conclusão final: apenas o amor verdadeiro é capaz de enfrentar a sociedade preconceituosa que se opõe às minorias. Ter um filho diferente extrapola qualquer tipo de amor humano e ainda assim é um amor profundo, é o amor ao próximo.

Tem muito suicida que é uma pessoa que teve seu indivíduo partido. Os pais não aceitaram que ele fosse diferente. Pode parecer piegas e a coisa mais óbvia do mundo, mas só o amor nos permite essa compreensão. E é o amor verdadeiro. Não é o amor à forma, não é o amor ao que vai sair no jornal, não é o amor ao primeiro lugar, não é o amor ao tamanho do salário. É o amor profundo, que nos liga ao próximo. E o amor é uma coisa que a sociedade despedaçou e distorceu. Esse livro é uma prova de amor para as pessoas entenderem que têm de abrir o coração, ser generosas, se despir de vaidades e entrar em contato com o indivíduo. ${ }^{278}$

\subsection{3}

\section{Jean Vanier: a fraternidade e o encontro}

Considerar a profundidade do sofrimento com algo que pode aniquilar o homem e ao mesmo tempo levar em conta a sua possibilidade de libertar esse

${ }^{277}$ Ibid.

${ }^{278}$ Ibid. 
mesmo homem parece um paradoxo. Entretanto, Jean Vanier assevera que as pessoas com deficiência em alto grau permanecem na presença de Deus, mas, para quem as observa, imagina que aparentemente passam seus dias sem nada fazer. "Sua imobilidade obriga-as a conservar os olhos e o coração fixos no essencial, na própria fonte de vida. Seus sofrimentos e sua agonia são fecundos: tornam-se fonte de vida".

Jean Vanier é fundador de L'Arche, casa ecumênica de acolhida a pessoas com deficiência. A espiritualidade da Arca está centrada nos princípios estabelecidos pelo Concílio Vaticano II, quais sejam: o profundo valor do indivíduo, qualquer que seja sua cultura, religião, modo de viver e suas habilidades. ${ }^{279}$

Vanier qualifica as pessoas com deficiência como "mestres de humanidade", porque essas pessoas suscitam nos seus interlocutores sentimentos de profunda compaixão, que vem demonstrada por meio de uma relação de comunhão de amor e de perdão. ${ }^{280}$

279 VANIER J., Signs ot times. Seven paths of hope for a troubled world. London: Darton, Longman and Todd, 2013, ebookkindle., loc 96.

280 Vanier diz que as pessoas com deficiência são "mestres de humanidade" porque se lhe escutamos entramos na via da compaixão, que é o coração do Evangelho: "seja misericordioso como o Pai é misericordioso; não julgueis para não seres julgados; não condeneis para não seres condenados; perdoai para serdes perdoado". Quando se abre o coração à pessoa com deficiência revela-se uma relação que ele define como uma relação de pessoa para pessoa na qual Deus está presente. (...). Em comunidade amar é revelar a pessoa amada o quanto ela é importante e que ela tem valor. Na comunidade fazemos isso por meio da compreensão de suas necessidades, de seu sofrimento, de seus questionamentos e também do lugar que ocupa na Igreja. Esse amor consiste em entrar em relação de comunhão e em um senso de pertencer uns com os outros. Este amor leva ao perdão pois nos ferimos uns aos outros e somos chamados a entrar no mistério do perdão. Eis o texto: "Lei dice che gli handicappati e le persone che soffrono sono "maestri di umanità", perché? $\mathrm{Ci}$ attirano, anzi ci chiamano, qualche volta fisicamente, e se noi li ascoltiamo ci fanno entrare nella compassione che è il cuore del Vangelo: "siate misericordiosi come Mio Padre è misericordioso, non giudicate e non sarete giudicati, non condannate e non sarete condannati, perdonate e sarete perdonati". Essi ci insegnano - se uno entra in relazione con loro, se si è toccati da loro - ad aprire il cuore ad una relazione che definirei da persona a persona, in cui Dio è presente. (...). In comunità amare qualcuno vuol dire rivelargli che è importante, che ha un valore. Lo facciamo attraverso l'ascolto, la comprensione dei suoi bisogni, delle sue sofferenze, del suo richiamo profondo, ed anche attraverso la comprensione del posto che ha nella Chiesa. Questo amore consiste nell'entrare finalmente in una relazione di comunione, in un senso di appartenenza degli uni con gli altri. E poi questo amore ci porta al perdono, perché ci feriamo gli uni gli altri e siamo chiamati, perciò, ad entrare nel mistero del perdono". (Cf. BUSOLINI D. Entrevista com Jean Vanier. L'Anno Santo nelle parole di Jean Vanier, fondatore dell' "Arca" e di "Fede e Luce". La testimonianza di fede delle persone con handicap, "maestre di umanità". "Un anno speciale per ricevere il dono di Gesù". Disponível em: <http://www.vatican.va/jubilee_2000/pilgrim/documents/ju_gp_07032000_p-8a_it.html>.Acesso em 25 de junho de 2016. 
Para Vanier, essa experiência de ternura acontece na comunidade da Arca, porque os valores da comunidade não estão centrados nas culturas da independência, do sucesso e do ter. Esses valores são entendidos como negativos, uma vez que "rotulam" como inferiores àquelas pessoas que se encontram fora desse círculo. De fato, o que faz as pessoas na Arca sentirem-se felizes, é pertencer, estabelecer vínculos e ser elas mesmas, adquirindo liberdade interior e assim se tornam mais abertas para si mesmo e para os outros. ${ }^{281}$

Vanier, ao longo de sua experiência na Arca, é alguém que percebe e exprime com clareza a dialética que existe entre "verdade", "encontro" e "sofrimento" ${ }^{282}$, pois a realidade da Arca se relaciona às pessoas vulneráveis.

Nesse sentido, por entender que o sofrimento deve ser vivenciado positivamente, estabelece um confronto entre duas realidades diversas: sofrimento e realização, entendendo que a possibilidade de realização de amor no sofrimento se dá por meio de um "encontro", lugar por excelência onde há trocas, aprendizado e onde a vida transcende seus limites.

Em uma sociedade em que ser bom está vinculado a ter sucesso, é comum a pessoa com deficiência sentir-se humilhada, pois se sente fora desse contexto. A resposta é o medo de ser humilhado. A humilhação vem acompanhada de sentimentos de vitimização, de desapontamento, de desaprovação e o antídoto para tais sentimentos tem lugar com base em um verdadeiro "encontro" que se

\footnotetext{
${ }^{281}$ VANIER, J., Signs of the times, loc 102.

${ }^{282}$ Vanier diz que o grito de amor, de comunhão e de reconhecimento que se levanta dos coraçõas de pessoas com necessidades, revela a fonte de amore em nós e também nossa capacidade de dar amor. Ao mesmo tempo pode também reveler nossa dureza de coração e nossos medos. Seus gritos são tão exigentes e nós frequentemente somos seduzidos pela riqueza, pelo poder e pelos valores da sociedade. Nós queremos subir a escada da promoção humana: queremos ser reconhecidos pela nossa eficiência, poder e virtudes. O grito do pobre ameaça a rica pessoa dentro de nós. Estamos preparados para dar dinheiro, às vezes, e também para dar um pouco do nosso tempo, mas temos medo de dar nossos corações, medo de entrar em uma relação pessoal de amor e de comunhão com eles. Porque se assim o fizermos, teremos que morrer para todo o nosso egoísmo e para toda a dureza do nosso coração. Eis o texto: "The cry for love and communion and for recognition that rises from the hearts of people in need reveals the fountain of love in us and our capacity to give life. At the same time, it can reveal our hardness of heart and are fears. Their cry is so demanding, and we are frequently seduced by wealth, power and the values of our societies. We want to climb the ladder of human promotion; we want to be recognized for our efficiency, power and virtue. The cry of the poor is threatening to the rich person within us. We are sometimes prepared to give money and a little time, but we are frightened to give our hearts, to enter into a personal relationship of love and communion with them. For if we do so, we shall have to die to all our selfishness and to all the hardness of our heart". (Cf. VANIER, J., Quotes by Jean Vanier. Disponível em: <http://www.goodreads.com/quotes/1743689-the-cry-for-love-and-communionand-for-recognition-that $>$. Acesso em 25 de junho de 2016.
} 
desdobra em dois sacramentos, que é como Vanier os denomina: "sacramento da fraternidade" e "sacramento do encontro". ${ }^{283}$ Ambos conduzem o ser humano à aceitação e à humildade, uma vez que o encontro com o outro humaniza e torna o homem humilde, revelando seu real valor individual. ${ }^{284}$

Nesse encontro há a possibilidade de aceitação de quem se é sem floreios ou subterfúgios. Um encontro que vê o que as aparências escondem e revela a fragilidade e necessidade que se tem de ajuda: uma exposição de vulnerabilidades. ${ }^{285}$

O encontro com o outro que sofre abre a perspectiva de transformação do eu, pois o encontro com a pessoa que é pobre, humilhada e rejeitada tem o poder de transformar e mostrar o profundo sentido da vida de cada qual. ${ }^{286}$ Essas pessoas quando se mostram agradecidas fortalecem laços de amor que são experimentados por seus cuidadores. Nesse sentido, a experiência ultrapassa a dimensão do ser admirado para a dimensão do ser amado e, então, o verdadeiro e profundo sentido do valor pessoal é intelectualmente e espiritualmente alcançado. $^{287}$

Adentrando em um plano mais profundo o "sacramento do encontro" tem seu maior valor e real felicidade na "comunhão" e na "presença". É um encontro transformador, pessoal e cuja experiência indescritível tenta ser elucidado por Vanier na primeira pessoa: "Como posso explicar que apesar de tudo o que está ferido em mim eu permaneço em comunhão com Deus?"288 Essa transformação tem um poder que as palavras não explicam e que somente pode ser

\footnotetext{
${ }^{283}$ VANIER, J., Signs of the times, loc. 209.

284 Ibid., loc. 281.

285 Ibid., loc. 494-498.

${ }^{286}$ Ibid., loc. 502.

${ }^{287}$ Cf. Ibid., loc. $506-514$.

${ }^{288}$ A reflexão de Vanier parte do entendimento de que o que mais se tem necessidade na vida é de sentir-se amado e não exatamente de se sentir "normal". Sentir-se amado para além de faltas ou segredos pessoais. Vanier reflete sobre si mesmo. E diz que esse é o amor de Deus que o ama apesar dos seus pecados, seus vícios, suas compulsões. E ele afirma que apesar de tudo o que está ferido nele, ainda assim, seu coração continua em comunhão com Deus. De fato a comunhão com quem tenha sido humilhada abre o sera o infinito. "This is the way God loves me, sinner that $\mathrm{i}$ am, with my addictions, compulsions and my flights from myself. How can I explain that despite all that is wounded in me, in my hearts I remain in communion with God? Communion with someone who has been humiliated thus opens me to the infinite".(Cf. Vanier, J., Signs ot the times loc. 573577).
} 
experimentada e revela o prazer de estar vivo e livre. ${ }^{289}$ Descobre-se a presença de Deus na presença do outro. ${ }^{290}$

\subsection{4 A ressonância do pensamento cultural na pessoa de Francisco}

A preocupação de Francisco, no que diz respeito à opção preferencial pelos pobres e a realidade sofrida nas periferias geográficas e existenciais, toca de perto a questão levantada por Victor Frankl sobre a busca de sentido no sofrimento.

Francisco aborda o tema do sofrimento colocando em pé de igualdade todas as pessoas com deficiência ou não, pois, diz ele, um dia, em um dado momento da vida, todos se depararão com fragilidades e doenças em razão das quais a pergunta se impõe: qual o sentido da vida?

Na realidade todos nós, mais cedo ou mais tarde, somos chamados a encarar e, às vezes, a lutar contra as fragilidades e as doenças, nossas e alheias. E como são diferentes os rostos com que se apresentam estas experiências, tão típica e dramaticamente humanas! Mas sempre nos colocam, de forma mais aguda e premente, a questão do sentido da vida. ${ }^{291}$

Se para alguns, essa experiência dolorosa acontece apenas um dia, para outros ela é companheira inseparável, que é justo o caso da pessoa com deficiência. E exatamente porque muitas dessas pessoas têm a força e a capacidade de transformar dor em amor é que Francisco as chama de "recursos de humanidade".

Em Frankl a resposta sobre a busca do sentido da vida e sobre o sentido do sofrimento está justamente em transformar sofrimento em amor, a partir da certeza de que o amor está para além da presença física, uma vez que se centraliza na contemplação amorosa da imagem espiritual da pessoa amada. Contemplar amorosamente é amar.

Em Francisco a felicidade se expressa de vários modos e, a cada expressão de amor, corresponde à possibilidade de se resgatar o outro que se encontra nas

\footnotetext{
${ }^{289}$ Ibid., loc. 585 .

${ }^{290}$ Ibid., loc. 591.

291 FRANCISCO, Jubileu Extraordinário da Misericórdia. Jubileu dos doentes e das pessoas portadoras de deficiência, 12 de junho de 2016. Disponível em: <https://w2.vatican.va/content/francesco/pt/homilies/2016/documents/papafrancesco_20160612_omelia-giubileo-ammalati-disabili.html>. Acesso em 26 de junho de 2016.
} 
periferias existenciais e geográficas para um mundo em que o abraço e o sorriso se irradiam. De toda forma, assim como Frankl, Francisco elege o amor como força motriz que dá sentido a vida, pois, ao se saber amado, o ser humano é capaz de sair do casulo e caminhar na estrada do amor.

Aliás, a felicidade que deseja cada um pode exprimir-se de muitos modos, mas só é possível alcançá-la se se for capaz de amar. Esta é a estrada. É sempre uma questão de amor, não há outra estrada. O verdadeiro desafio é o de quem ama mais. Quantas pessoas com deficiência e enfermas se reabrem à vida, logo que descobrem que são amadas! E quão grande amor pode brotar dum coração, mesmo só através dum sorriso! (...) O modo como vivemos a doença e a deficiência é indicação do amor que estamos dispostos a oferecer. A forma como enfrentamos o sofrimento e a limitação é critério da nossa liberdade em dar sentido às experiências da vida, mesmo quando nos parecem absurdas e não merecidas. ${ }^{292}$

Tanto para Frankl quanto para Francisco o amor se identifica com alguém.

Em Frankl esse alguém é a esposa, também refém nos campos de concentração. Um amor de resgate em meio ao drama que se desenvolveu e que foi o motivo pelo qual Frankl conseguiu sustentar-se embalado pela lembrança de sua presença, em um diálogo espiritual em que Frankl vislumbrou que o amor é forte como a morte.

Para Francisco esse alguém é o próprio Deus, pois acolher o amor de Deus devolve o sentido da vida e resgata o homem da consciência isolada e da autorreferencialidade ${ }^{293}$, sendo Deus a fonte do amor maior. ${ }^{294}$

Uma vez que se acolhe a Deus, se acolhe e se inclui as pessoas com deficiência e assim o homem está aberto a "ajudar e reconhecer que o único caminho é aprender a encontrar os demais com a atitude adequada, é valorizá-los e aceitá-los como companheiros de estrada, sem resistências interiores". ${ }^{295}$ Nesse sentido Francisco está afinado com Olivia Byington.

Francisco clama a sociedade por uma "cultura de inclusão" e por uma "cultura de acolhimento", por entender que é preciso que se tenha respeito por essas pessoas, dando a elas a possibilidade de viverem em uma sociedade inclusiva, generosa e acolhedora.

\footnotetext{
292 Ibid.

${ }^{293}$ Francisco assim se refere ao amor de Deus: "Se alguém acolheu esse amor que lhe devolve o sentido da vida, como pode conter o desejo de comunica-lo aos outros? (Cf. EG 8).

294 Ibid., 7.

${ }^{295}$ EG 91.
} 
Fortalecendo essa postura de inclusão, Francisco entende que as pessoas com deficiência devem receber os sacramentos, pois todos devem participar de alguma forma da vida eclesial, uma vez que todos fazem parte da comunidade, e "nem sequer as portas dos sacramentos se deveriam fechar por uma razão qualquer."296

O Papa Francisco defendeu (...) o valor da diversidade e pediu que as pessoas com incapacidades sejam acolhidas plenamente nas comunidades em que vivem, eliminando os preconceitos, as exclusões e as marginalizações. "No caminho da inclusão destas pessoas com incapacidades ocupam naturalmente um lugar decisivo a sua admissão aos Sacramentos", vincou o chefe da Igreja Católica, citado pela agência espanhola Efe. ${ }^{297}$

O preconceito é alvo de duras críticas de Francisco, pois a exclusão é fruto dentre outras coisas, do preconceito, que por inibir aquele que é excluído, gera um fechamento no sujeito que não consegue integrar-se plenamente na sociedade. $\mathrm{O}$ isolamento e o fechamento não são caminhos de comunhão e Francisco entende que "é possível dialogar, ouvir uns aos outros, fazer programas conjuntos e deste modo superar a suspeita e o preconceito e construir uma convivência cada vez mais segura, pacífica e inclusiva". 298

Francisco fala ao mundo, mas, não se pode esquecer, que no mais das vezes, tem como parâmetro a Igreja que está nas cidades. Por isso vai dizer que a vida consagrada é exemplo a ser seguido no que diz respeito a viver em comunidade e na diversidade, pois a vida consagrada é comunitária. De toda sorte fica aqui registrado a importância que Francisco dá a diversidade.

Hoje a cultura predominante é individualista, centrada em direitos subjectivos. É uma cultura que corrói a sociedade a partir da sua célula primária, que é a família. A vida consagrada pode ajudar a Igreja e a sociedade inteira, dando testemunhos de fraternidade, que é possível viver juntos como irmãos, na diversidade: isto é importante! Na comunidade as pessoas não se escolhem antes, mas encontram-se com outras pessoas, diferentes por índole, idade, formação, sensibilidade... e no entanto procuram viver como irmãos ${ }^{299}$.

${ }^{296} \mathrm{EG} 47$.

297 DNOTICIAS. PT., Papa Francisco defende inclusão das pessoas com deficiência e fim dos preconceitos, 11 de junho de 2014. Disponívelm em: $<$ http://www.dnoticias.pt/actualidade/mundo/593263-papa-francisco-defende-inclusao-daspessoas-com-deficiencia-e-fim-dos-preco>. Acesso em 02 de julho de 2016.

298 FRANCISCO, Angelus, 16 de novembro de 2014. Disponível em: <http://m2.vatican.va/content/francesco/pt/angelus/2014/documents/papafrancesco_angelus_20141116.html>. Acesso em 03 de julho de 2016.

${ }^{299}$ FRANCISCO, Discurso aos participantes da Assembléia Nacional da Conferência Italiana dos $\begin{array}{llllll}\text { Superiores } & \text { Maiores. } & 07 & \text { de novembro de 2014. Disponível }\end{array}$ 
O discurso de Olívia em relação a uma sociedade que prestigia padrões de beleza, quase que inalcançáveis, em detrimento do que há de singular no ser humano, é semelhanta à homilia de Francisco no Jubileu dos doentes e das pessoas portadoras de deficiência. Francisco também observa que as pessoas com deficiência, de alguma forma, são escondidas para não "melindrar" às outras pessoas, para "não estorvar o ritmo dum bem-estar falso", pois de certa forma, não correspondem ao padrão dominante.

Conhecemos a objeção que se levanta, sobretudo nestes tempos, à vista duma vida marcada por graves limitações físicas; considera-se que é impossível ser feliz uma pessoa enferma ou deficiente, porque incapaz de realizar o estilo de vida imposto pela cultura do prazer e da diversão. Num tempo como o nosso, em que o cuidado do corpo se tornou um mito de massa e consequentemente um negócio, aquilo que é imperfeito deve ser ocultado, porque atenta contra a felicidade e a serenidade dos privilegiados e põe em crise o modelo dominante. É melhor manter tais pessoas segregadas em qualquer «recinto» - eventualmente dourado - ou em «reservas» criadas por um compassivo assistencialismo, para não estorvar o ritmo dum bemestar falso. Por vezes chega-se a sustentar que é melhor desembaraçar-se o mais rapidamente possível de tais pessoas, porque se tornam um encargo financeiro insuportável em tempos de crise. Na realidade, porém, como é grande a ilusão em que vive o homem de hoje, quando fecha os olhos à enfermidade e à deficiência. ${ }^{300}$

Olívia conclui que a realidade de quem lida com a pessoa com deficiência é de fato difícil e sofrida, mas para além de qualquer dificuldade existe o verdadeiro amor que supre qualquer necessidade e que torna possível conviver com o diferente. Francisco pensa de igual forma e isso fica nítido quando diz que "o modo como vivemos a doença e a deficiência é indicação do amor que estamos dispostos a oferecer". O sofrimento não é apenas físico, há o sofrimento que envolve a alma tornando-a triste, porque carente de amor. Os sofrimentos nos deixam fracos e indefesos, mas não se pode correr o risco de perder a ocasião da vida: "amar apesar de tudo. Amar apesar de tudo". 301

Em Francisco esse amor se faz presente na dimensão da fraternidade e do encontro. Portanto o pensamento de Francisco está em sintonia com o de Jean Vanier.

em:<https://w2.vatican.va/content/francescomobile/pt/speeches/2014/november/documents/papafrancesco_20141107_conferenza-italiana-superiori-maggiori.html>. Acesso em 01 de julho de 2016.

${ }^{300}$ FRANCISCO, Jubileu dos doentes e das pessoas portadoras de deficiência, 12 de junho de 2016.

301 Ibid. 
A fraternidade em Francisco está radicada no Pai o que lhe assegura um caráter místico. E o que Vanier denomina "sacramento da fraternidade" é para Francisco a "mística" de viver junto, de misturar-se, abraçar-se, de viver uma experiência de fraternidade de encontro e de solidariedade entre todos. ${ }^{302}$ Para além disso, a fraternidade tem o condão de curar as feridas recebidas, seja por agressões injustas, seja por ingratidões como nos diz Francisco:

Nisto está a verdadeira cura, pois o modo de nos relacionarmos com os outros que nos cura em vez de nos adoecer é uma fraternidade mística contemplativa, que sabe ver a grandeza sagrada do próximo, que sabe descobrir Deus em cada ser humano, que sabe tolerar as moléstias da convivência agarrando-se ao amor de Deus, que sabe abrir o coração ao amor divino para procurar a felicidade dos outros como a procura o seu Pai bom. ${ }^{303}$

Assim como Francisco, Vanier define a verdade como um "encontro": "Existe um movimento universal da verdade, o encontro entre pessoas, e o Papa precisamente está anunciando que (a missão) não é 'proteger' a Igreja Católica, mas ajudar as pessoas a se encontrarem (com suas diferenças)". 304

Vanier reconhece que as pessoas com deficiência são seres humanos que tem muito que ensinar e as chama de "mestres de humanidade". Francisco as chama de "recursos de humanidade".

Assim como Francisco, Vanier tem um pensamento inclusivo em relação a essas pessoas e atesta que é a partir de um "encontro", ao qual ele chama de "sacramento do encontro", que o sofrimento passa a ser ressignificado.

Francisco amplifica a amplitude do encontro, que passa a ser cultura, a "cultura do encontro" que por ter maior envergadura não se limita a abraçar a pessoa com deficiência, mas busca a promoção integral de todos os seres humanos.

Ambicionando a um pontificado de proximidade e encontro, Francisco fala para o mundo, mas seu público por excelência são os membros da Igreja. Por isso ao falar sobre a "cultura do encontro", destaca que a missão da Igreja é levar o

\footnotetext{
302 Cf. EG 87.

${ }^{303}$ Cf. EG 92.

${ }^{304}$ BOSCH M. D., Jean Vanier fundador da L'Arche "os mais rejeitados nos levam a Deus". Uma entrevista exclusiva da Aleteia com um homem extraordinário, que vive e trabalha com "gente de coração.19 de abril de 2016. In: Aleteia. Disponível em: <http://pt.aleteia.org/2016/04/19/jeanvanier-fundador-da-larche-os-mais-rejeitados-nos-levam-a-deus/>. Acesso em 24 de junho de 2016.
} 
anúncio evangélico. É nesse anúncio que se dá o encontro; encontro com Deus e com o outro a quem o anúncio é dirigido.

A questão da proximidade ${ }^{305}$ é substancial na perspectiva de Francisco, pois estar próximo é sair de si e ir em direção ao encontro com o outro, que se dá na proximidade física e no amor; um encontro interplanetário, com todo o povo; a superação do medo de se sentir invadido, abrindo-se na dimensão do Evangelho, abraçando o outro com seus sofrimentos e suas reivindicações, com sua alegria contagiosa, permanecendo lado a lado. ${ }^{306}$

Para mim a evangelização exige sair de si mesmo; requer a dimensão do transcendente: o transcendente na adoração de Deus, na contemplação, e o transcendente para com os irmãos, para com o povo. Sair de si, sair! Para mim isto é como o nó da evangelização. Sair significa chegar, ou seja, proximidade. Se não saíres de ti mesmo, não terás proximidade! Proximidade. Estar próximo das pessoas, próximo de todos, de todos aqueles aos quais devemos estar próximos. Todo o povo. Sair. Proximidade. Não se pode evangelizar sem proximidade. Proximidade, mas cordial; proximidade no amor, também proximidade física; estar próximo. ${ }^{307}$

Vive-se uma cultura de desencontro, de frivolidade, de descarte e Francisco atesta a necessidade de se trazer para a Igreja esses que sofrem. A cultura do encontro remete o homem à necessidade de acolher esse irmão que encontra no caminho. Para além de tudo a cultura do encontro é parte da célula familiar rumo à humanidade para o engrandecimento do homem, pois diz Francisco: A única maneira para uma pessoa, uma família, uma sociedade crescer, a única maneira para fazer avançar a vida dos povos é a cultura do encontro. ${ }^{308}$

Sair em direção às periferias existenciais e geográficas, abrir-se à alteridade, à gratuidade, à fraternidade, à solidariedade, deixando para trás a

\footnotetext{
305 Vós, sacerdotes, inspirais-me uma só palavra: proximidade.(...) Próximos do Senhor, e proximidade ao povo, estai próximos do povo. (Cf. FRANCISCO, Discurso aos participantes no $37^{\circ}$ encontro nacional da renovação carismática católica, 01 de junho de 2014 . Disponível em: <http://w2.vatican.va/content/francesco/pt/speeches/2014/june/documents/papa-

francesco_20140601_rinnovamento-spirito-santo.html>). Acesso em 22 de junho de 2015.

306 Cf. EG 88.

${ }^{307}$ FRANCISCO, Diálogo com os alunos dos Pontifícios Colégios e Internatos de Roma, 12 de maio de 2014. Disponível em: <http://w2.vatican.va/content/francesco/pt/speeches/2014/may/documents/papafrancesco_20140512_pontifici-collegi-convitti.html>. Acesso em 20 de julho de 2015.

${ }^{308}$ FRANCISCO, Encontro com a classe dirigente do Brasil, 27 de julho de 2013. Disponível em: <https://w2.vatican.va/content/francesco/pt/speeches/2013/july/documents/papafrancesco_20130727_gmg-classe-dirigente-rio.html>. Acesso em 25 de maio de 2015.
} 
autorreferencialidade; uma abertura ao encontro que se dá no caminhar e na proximidade, criando vínculos e semeando a paz.

O egoísmo e o isolamento criam sempre uma atmosfera asfixiante e pesada, que mais cedo ou mais tarde acaba por estiolar e sufocar. Ao contrário, serve um compromisso comum de todos para favorecer uma cultura do encontro, porque só quem consegue ir ao encontro dos outros é capaz de dar fruto, criar vínculos, criar comunhão, irradiar alegria, construir a paz. ${ }^{309}$

O pensamento de Francisco em relação às pessoas com deficiência, as quais são vistas como recursos de humanidade, foi justificado e ratificado pelos testemunhos e experiências de pessoas que conviveram e convivem com essa realidade.

De certa forma, cada qual a seu modo, buscou dar respostas ao sentido do sofrimento humano que se interpenetra com a pergunta e possível resposta sobre o sentido da vida.

A análise das respostas leva à conclusão de que a vitória sobre o sofrimento é a transformação do sofrimento em amor. No caso das pessoas com deficiência fica nítido que o que de início gera medo ou até mesmo repulsa ao final é a grande fonte de amor. Por isso mesmo Francisco as vê como pessoas que nos ensinam a viver; são escolas de vida, fonte de alegria e felicidade.

É possível dizer que em Francisco o amor que une é também aquele que se abre à diversidade e que acolhe a diferença. Nesse sentido diz Francisco, um ato que demonstra esse estar junto, e esse engrandecimento mútuo se traduz em um gesto simples: um sincero aperto de mão. ${ }^{310}$

A realidade engrandecedora da comunhão com o diverso é que, além do amor que integra a relação entre as partes, há uma riqueza que se interioriza nessa relação, porque "cada um tem a sua riqueza, é diverso, é como se falasse outra

\footnotetext{
${ }^{309}$ FRANCISCO, Discurso aos membros do Corpo Diplomático acreditado junto a Santa Sé, 13 de janeiro de 2014. Disponível em: <https://w2.vatican.va/content/francesco/pt/speeches/2014/january/documents/papafrancesco_20140113_corpo-diplomatico.html>. Acesso em 27 de julho de 2015.

${ }^{310}$ Há um gesto lindíssimo que nós, pessoas humanas temos, um gesto que fazemos quase sem refletir, mas muito profundo: apertar a mão. Quando eu aperto a mão, ponho em comum contigo aquilo que tenho - se for um aperto de mão sincero - dou-te a mão, dou-te aquilo que é meu e tu dás-me o que é teu. E isto faz muito bem a todos. E pensemos que todas as vezes que eu aperto a mão a outro, dou algo de meu e recebo algo dele. Também isto nos faz crescer. (Cf. FRANCISCO, Discurso aos participantes no Congresso para pessoas deficientes promovido pela Conferência Episcopal Italiana, 11 de junho de 2016. Disponível em: <https://w2.vatican.va/content/francesco/pt/speeches/2016/june/documents/papafrancesco_20160611_convegno-disabili.html>. Acesso em 24 de junho de 2016.
} 
língua. É diverso, porque se expressa de maneira diferente. E este facto é uma riqueza". ${ }^{311}$

Em Francisco a cultura do encontro é expressão maior da inclusão, que aceita as diferenças e a diversidade, reconhecendo que o mundo é melhor quando a solidariedade se impõe.

Não compreende o verdadeiro sentido da vida, que inclui também a aceitação do sofrimento e da limitação. O mundo não se torna melhor quando se compõe apenas de pessoas aparentemente «perfeitas» (para não dizer «maquilhadas»), mas quando crescem a solidariedade, a mútua aceitação e o respeito entre os seres humanos. ${ }^{312}$

Os mestres de humanidade são realmente aqueles que transformam sofrimento em amor e buscam as possibilidades de vencerem as barreiras que os limitam. Eles entendem que o sentido da vida está fora da vida e, portanto, para além da vida. Por isso Francisco diz: "as alegrias mais belas e espontâneas que vi ao longo da minha vida, são as alegrias de pessoas muito pobres que têm pouco a que se agarrar". ${ }^{313}$ Essas pessoas são sábias, agarram-se a Deus e crêem no seu amor, pois elas sabem que apenas Ele pode mantê-las de pé e é por isso que nesse encontro não há perdedores, todos ganham, pois "bebem na fonte do amor maior, que é o de Deus, a nós manifestado em Jesus Cristo". 314

\section{2 O encontro de Francisco com as pessoas com deficiência}

$\mathrm{O}$ encontro entre Francisco e as pessoas com deficiência acontece tanto em nível presencial, quanto em nível magisterial. Francisco promove a dignidade dessas pessoas por meio de um Magistério diretamente endereçado a elas. Nesse sentido é fato que promove a cultura do encontro, mas além do mais, evidencia a exclusão, o descarte e toda a forma de distanciamento a que estão submetidas. Dessa forma, dá visibilidade a essas pessoas demonstrando seus valores, como por

\footnotetext{
311 Pensemos num mundo no qual todos são iguais: seria um mundo tedioso! É verdade que algumas diversidades são dolorosas, todos o sabemos, aquelas que têm raízes nalgumas doenças... mas também as diversidades nos ajudam, nos desafiam e nos enriquecem. Por isso, nunca se deve ter medo das diversidades: esse é precisamente o caminho para melhorar, para sermos melhores e mais ricos. (Cf. Ibid).

312 FRANCISCO, Jubileu Extraordinário da Misericórdia. Jubileu dos doentes e das pessoas portadoras de deficiência, 12 de junho de 2016.

${ }^{313}$ Cf. EG 7.

${ }^{314}$ Ibid.
} 
exemplo, no caso dos atletas paralímpicos, mas também, chama a atenção da sociedade que, em face do preconceito, alija as pessoas com deficiência da realidade social.

O preconceito e a discriminação rompem a cadeia do diálogo, produzindo um isolamento, cujo efeito na vítima é o de sentir-se renegada, desconsiderada, pois, "diante de uma pessoa com deficiência física ou motora, sensorial ou mental, as pessoas vivem sentimentos contraditórios: desde a repulsa até a compaixão, a pessoa excluída sente-se não-pessoa".

Há que se buscar uma atitude aberta, tanto em nível pessoal como em nível nacional, uma atitude que favoreça o diálogo e que chame para perto a pessoa com deficiência, cumprindo-se dessa forma, não só as leis que a tornam sujeito de direitos e de obrigações, mas, também, em âmbito subjetivo e objetivo, privilegiando o encontro que derruba os muros mais impenetráveis do preconceito.

Francisco aponta para essa realidade com palavras fortes, chamando à visibilidade os "exilados ocultos", esses a quem o preconceito retira o que lhes é de direito: dignidade, trabalho, o que pode levá-los a sentimentos de desesperança.

Mas, ao lado dos migrantes, deslocados e refugiados, há muitos outros «exilados ocultos» (Angelus, 29 de Dezembro de 2013), que vivem dentro das nossas casas e famílias. Penso sobretudo nos idosos e nos deficientes, bem como nos jovens. Os primeiros são objecto de rejeição, quando se consideram como um fardo e «presenças molestas», (Ibid.), ao passo que os últimos são descartados negandolhes perspectivas de trabalho concretas para construírem o seu próprio futuro. Aliás, não há pobreza pior do que aquela que priva do trabalho e da dignidade do trabalho (cf. Discurso aos participantes no encontro mundial dos movimentos populares, 28 de Outubro de 2014), reduzindo-o a uma forma de escravidão. ${ }^{315}$

A Igreja deve vencer essa barreira indo ao encontro dessa fatia da sociedade e fazendo-se próxima, em gestos e em atitudes, não ser indiferente aos que sofrem, nem alheia, nem distante, mostrando com o testemunho a proximidade de Deus que é misericórdia, generosidade, providência e caridade para com os pobres, doentes e inválidos. ${ }^{316}$

\footnotetext{
${ }^{315}$ FRANCISCO, Discurso aos membros do Corpo Diplomático Acreditado junto a Santa Sé, 12 de janeiro de $2015.2015 /$ Disponível em: <http://w2.vatican.va/content/francesco/pt/speeches/2015/january/documents/papafrancesco_20150112_corpo-diplomatico.html>. Acesso em 04 de fevereiro de 2016.

${ }^{316}$ Cf. FRANCISCO, Discurso às Misericórdias da Itália e aos grupos $\left\langle<\right.$ Fratres $\gg$ no $30^{\circ}$ aniversário da Audiência com o Papa João Paulo II, 14 de junho de 2014.
} 
A alteridade, a fraternidade e a disponibilidade para com o outro são faces da cultura do encontro, cuja finalidade está na unidade, que supera preconceitos.

De fato as periferias existenciais são o que Francisco chama de "a noite do homem", e nesta "noite" devem ser construídas pontes e não muros, pois essa é Igreja sonhada por Francisco, uma Igreja que não tenha medo de entrar na noite dos homens, cujos ministros sejam capazes de caminhar junto a eles, na noite, como companhia que escuta; que na qualidade de Igreja sejam capazes de inserirse na sua conversa e que saibam dialogar com a solidão e com o desencanto ${ }^{317}$, e, portanto, Francisco pede por conversão e formação do clero.

A Igreja missionária que leva o Evangelho a todas as criaturas reconhece que as pessoas com deficiência não são corriqueiramente vistas nas cidades, levando a crer que estejam confinadas em suas residências, por falta de acolhimento, por não haver quem conheça a sua linguagem, por falta de meios de locomoção, muitas vezes por vergonha e por incompreensão. Nesse sentido, os agentes pastorais são chamados a abrir caminho em meio ao isolamento que as cerca, para que o Evangelho as alcance.

Em fidelidade ao Evangelho e em resposta às necessidades urgentes do presente, somos chamados a ir ao encontro daqueles que se encontram nas periferias existenciais das nossas sociedades e a manifestar uma solidariedade especial para com os nossos irmãos e irmãs mais vulneráveis: os pobres, os portadores de deficiência, os nascituros, os enfermos, os migrantes, os refugiados, os idosos e os jovens desempregados. ${ }^{318}$

As dificuldades encontradas não podem nem devem minar a resolução pastoral de buscá-las; os agentes pastorais devem seguir em frente, não se deixando vencer pelos obstáculos, pela sensação derrota ou pelo pessimismo. ${ }^{319} \mathrm{O}$ mesmo vale para as pessoas com deficiência: os obstáculos que encontram devem ser encarados como motivo de superação e não de derrota.

\footnotetext{
${ }^{317}$ FRANCISCO, Encontro com o Episcopado Brasileiro em 27 de julho de 2013. Disponível em: $<$ http://w2.vatican.va/content/francesco/pt/speeches/2013/july/documents/papafrancesco_20130727_gmg-episcopato-brasile.html>. Acesso em 28 de maio de 2015. 318 FRANCISCO, Mensagem ao cardeal Kurt Koch por ocasião da $10^{a}$ Assembleia Geral do Conselho Ecuménico das Igrejas, 04 de outubro de 2013. Disponível em: <https://w2.vatican.va/content/francesco/pt/messages/pont-messages/2013/documents/papafrancesco_20131004_world-council-churches.html>. Acesso em 30 de junho de 2015. ${ }^{319}$ Cf. EG 85.
} 
Assim como seus predecessores, Francisco leva sua mensagem aos mais necessitados, em especial às pessoas com deficiência. Em seu discurso junto à Renovação Carismática eis as palavras de Francisco aos deficientes:

Os irmãos e as irmãs que sofrem, que têm uma doença, que são deficientes, são irmãos e irmãs ungidos pelo sofrimento de Jesus Cristo, imitam Jesus no momento difícil da sua cruz, da sua vida. Eles levam em frente esta unção do sofrimento por toda a Igreja. Muito obrigado, irmãos e irmãs; muito obrigado pelo vosso aceitar e ser ungidos pelo sofrimento. Muito obrigado pela esperança que testemunhais. ${ }^{320}$

As mensagens e discursos do Bispo de Roma para essa fatia da sociedade destacam a exclusão social e o preconceito em relação aos menos favorecidos, àqueles que povoam e que constituem as periferias existenciais.

As mensagens por uma Igreja solidária e fraterna, por uma sociedade acolhedora, pela necessidade de uma cultura do encontro, são proferidas e dirigidas às pessoas com deficiência no âmbito de seu Magistério.

Em sua visita pastoral junto às crianças com deficiência, Francisco chama a atenção para a sociedade que longe de acolher, descarta as pessoas mais débeis e frágeis, frisando que as pessoas menos favorecidas, as pessoas que vivem em dificuldade, são essas que merecem ser acolhidas; a cultura do acolhimento suplantando e eliminando a cultura do descarte. ${ }^{321}$

Em seu discurso junto aos cegos e surdos na Itália, sua reflexão aborda o seguinte tema: "Testemunhas do Evangelho para a cultura do encontro" no sentido de resgatar sua dignidade.

Mas pensemos em muitas pessoas (...) marcadas pela enfermidade e pela deficiência, para as curar e restituir à plena dignidade. É muito importante que precisamente estas pessoas se tornem testemunhas de uma nova atitude, que podemos denominar cultura do encontro. ${ }^{322}$

Citando o cego de nascença que Jesus curou, Francisco atesta sua exclusão em relação à sociedade da época: o homem foi excluído por ser cego e, ao ser

\footnotetext{
${ }^{320}$ FRANCISCO, Discurso do Papa Francisco aos participantes do $37^{\circ}$ encontro nacional da Renovação Carismática Católica.

${ }^{321}$ Cf. FRANCISCO, Encontro com as crianças com deficiência e os doentes do Instituto Seráfico, 04 de outubro de $2013 . \quad$ Disponível em: <http://w2.vatican.va/content/francescomobile/pt/speeches/2013/october/documents/papafrancesco_20131004_bambini-assisi.html〉>. Acesso em 22 de junho de 2015. ${ }^{322}$ FRANCISCO, Discurso ao Movimento Apostólico de Cegos (MAC) e à Pequena Missão para os Surdos-Mudos, 29 de março de 2014. Disponível em: $<$ http://w2.vatican.va/content/francesco/pt/speeches/2014/march/documents/papafrancesco_20140329_movimento-ciechi-missione-sordomuti.html>. Acesso em 22 de novembro de 2015.
} 
curado, foi excluído por seguir Jesus. Entretanto, e em realidade, ele não precisa dessa sociedade preconceituosa e desumana, pois passa a pertencer à comunidade fundamentada na fé e no amor fraterno. ${ }^{323}$

Eis as duas culturas opostas entre si. A cultura do encontro e a cultura da exclusão, a cultura do preconceito, porque se lesa e se exclui. A pessoa doente ou portadora de deficiência, precisamente a partir de sua fragilidade e de seus limites, pode tornar-se testemunha do encontro: o encontro com Jesus que abre à vida e à fé, e o encontro com os outros e a comunidade. Com efeito, somente quantos reconhecem a própria fragilidade, os próprios limites, podem construir relacionamentos fraternos e solidários, tanto na Igreja quanto na sociedade. ${ }^{324}$

E Francisco vai reforçar a busca e promoção da cultura do encontro por entender que ela possibilita à pessoa com deficiência a sair do isolamento deixando de ser participativas na sociedade.

Promovei sempre a cultura do encontro, da solidariedade, do acolhimento das pessoas com deficiência, não só pedindo as providências justas, mas favorecendo a sua participação activa na vida da sociedade. ${ }^{325}$

As deficiências sensoriais, intelectuais, motoras tendem a levar a pessoa com deficiência ao fechamento. Mas é preciso que tenham em vista o encontro comunitário que as permita ser conhecidas e valorizadas pelas suas capacidades, pois todos têm capacidades e todos têm limites.

E muitas vezes as pessoas que convivem com desvantagens ou deficiências podem dizer a todos, mediante a sua experiência, que não somos «mónades», não fomos feitos para viver isolados, mas para nos relacionarmos, completarmos, ajudarmos, acompanharmos e sustentarmos uns aos outros. A presença de pessoas portadoras de deficiência estimula todos a fazer comunidade, aliás, a ser comunidade, a aceitar-nos uns aos outros, com os limites que nos são próprios. Pois todos nós temos capacidades, mas todos também temos limites! ${ }^{326}$

E se essa convivência dá o testemunho da realidade limite de cada qual, também demonstra o que o amor fraterno é capaz de fazer: "ser solidário,

\footnotetext{
323 Ibid.

324 Ibid.

${ }^{325}$ FRANCISCO, Mensagem Áudio aos Sócios da União Italiana de cegos e a todos os deficientes visuais, 11 de junho de 2013. Disponível em: <https://w2.vatican.va/content/francesco/pt/messages/pont-messages/2013/documents/papafrancesco_20130611_audiomessaggio-ciechi.html>. Acesso em 11 de novembro de 2014. ${ }^{326}$ Cf. FRANCISCO, Discurso ao Conselho Nacional da União Italiana dos cegos e deficientes visuais por ocasião da festa de Santa Luzia, 13 de dezembro de 2014. Disponível em: $<$ https://w2.vatican.va/content/francesco/pt/speeches/2014/december/documents/papafrancesco_20141213_unione-ciechi-ipovedenti.html >. Acesso em 14 de setembro de 2015.
} 
compartilhar experiências, por em comum os próprios recursos, vivendo com alegria a dimensão associativa." ${ }^{\text {327 }}$

Todos nós temos necessidade da coragem para enfrentar as provações da vida. De modo particular as pessoas cegas e deficientes visuais precisam da intrepidez para não se fecharem, para não assumirem uma atitude de vítima mas, ao contrário, para se abrirem à realidade, aos outros e à sociedade; para aprenderem a conhecer e a valorizar as capacidades que o Senhor depositou em cada um, verdadeiramente em cada um, sem excluir ninguém. No entanto, para isto é necessário ter coragem, fortaleza de espírito! ${ }^{328}$

Em mensagem às pessoas com deficiência visual, Francisco de novo enfatiza a proposta de abertura ao outro, dessa vez por parte das pessoas com deficiência que são chamadas a abrir-se eclesial e socialmente.

A deficiência motora, sensorial ou intelectual sempre constitui uma tentação a fechar-se; mas pode tornar-se, graças ao amor dos pais, dos irmãos e doutras pessoas amigas, um estímulo para se abrir, compartilhar, comunicar de modo inclusivo; e pode ajudar à escola, a paróquia, as associações a tornarem-se mais acolhedoras para com todos, a não excluírem ninguém. ${ }^{329}$

Também a Igreja mais uma vez é chamada a agir com misericórdia para com os enfermos, para com os idosos, para com os portadores de deficiência, indo ao encontro dessa fatia da sociedade e fazendo-se próxima, em gestos e em atitudes.

Francisco faz um pedido para que se multiplique o amor concreto em obras que unam profissionalismo, trabalho qualificado e voluntariado como resultado da cultura do acolhimento e da fraternidade ${ }^{330}$ e que resultem em experiência de partilha.

A experiência da partilha fraterna com quantos sofrem abre-nos à beleza autêntica da vida humana, que inclui a sua fragilidade. Na salvaguarda e na promoção da vida, em qualquer fase e condição que ela se encontre, podemos reconhecer a dignidade e o valor de cada ser humano na sua individualidade, desde a concepção até à morte. ${ }^{331}$

${ }^{327}$ Cf. Ibid.

328 Ibid.

${ }^{329}$ FRANCISCO, Mensagem para o XLIX Dia Mundial das Comunicações Sociais, 23 de janeiro de 2015.2 Disponível em: <http://w2.vatican.va/content/francesco/pt/messages/communications/documents/papafrancesco_20150123_messaggio-comunicazioni-sociali.html >. Acesso em 14 de agosto de 2015.

${ }^{330}$ Cf. Encontro com as crianças com deficiência e os doentes do Instituto Seráfico, 04 de outubro de 2013.

${ }^{331}$ FRANCISCO, Discurso aos participantes na sessão plenária do Pontifício Conselho para a Pastoral no campo da saúde, 24 de março de 2014. Disponível em: 
Para tanto exorta a sociedade e a Igreja para que construam uma relação bilateral em que se aprende e se apreende a cultura das pessoas com deficiência. Nesse encontro acontece uma renovação cultural proveniente da inculturação, a evangelização em via de mão dupla, que deve se estender às categorias profissionais e intelectuais responsáveis pela formação de leigos que evangelizarão essas culturas. ${ }^{332}$ Dessa forma evangelizam-se os profissionais, as pessoas com deficiência e os leigos, que se tornam melhores fazendo o bem, pois o bem tende a comunicar-se. ${ }^{333}$

O dever de anúncio e de caridade é dever de todos os fiéis que contribuem nas suas respectivas paróquias, no âmbito da pastoral ordinária ${ }^{334}$, um dever que não é uma obrigação imposta, mas uma alegria que é sentida por aquele que evangeliza.

Esse anúncio é um enorme desafio face à virada cultural, constituindo-se em maior desafio face à pessoa com deficiência que se vê alijada de um processo cultural muitas vezes perverso, sentindo-se abandonada e abusada. Afinal diz Francisco: "não pode ser autêntico um sentimento de união íntima com os outros seres da natureza, se ao mesmo tempo não houver no coração ternura, compaixão e preocupação pelos seres humanos". 335

Em outra oportunidade lança um olhar aos atletas paralímpicos com palavras que reforçam a vontade de se superar, comum em todos os atletas, pois o esporte é uma competição consigo mesmo, no sentido de vencer as próprias barreiras, e com o outro, mediada pelo respeito que cada atleta tem pelos outros atletas.

Os atletas paralímpicos são a prova concreta de que limitações podem ser vencidas e o convívio entre os pares favorece a cultura do encontro, uma vez que há o congraçamento de diversas culturas. E o fortalecimento de valores internos na busca da auto superação; a visão do esforço individual que em sede de Olimpíadas se torna a visão de um esforço global, que chega como mensagem de

<http://m2.vatican.va/content/francescomobile/pt/speeches/2014/march/documents/papafrancesco_20140324_plenaria-operatori-sanitari.html>. Acesso em 14 de julho de 2015.

${ }^{332}$ EG 102.

${ }^{333}$ EG 9.

${ }^{334}$ EG 14.

${ }^{335}$ LS 91. 
encorajamento e de esperança a todos os atletas, sem exceção, é pois a prova viva da real possibilidade de que o ser humano tem a possibilidade de operar em nível de uma transcendência horizontal: o ser humano capaz de ultrapassar resultados, com o apoio de treinadores e parentes, desenvolvendo um trabalho em que a solidariedade se faz presente e, mormente, a graça divina.

O desporto promove contatos e relações com pessoas que provêm de culturas e ambientes diversos, habitua-nos a viver aceitando as diferenças, a fazer delas ocasião preciosa de enriquecimento recíproco e de descoberta. O desporto torna-se, sobretudo uma oportunidade valiosa para favorecer a cultura da inclusão e rejeitar a cultura do descartável. (...). O vosso testemunho, queridos atletas, é um grande sinal de esperança, É uma prova do facto que em cada pessoa existe um potencial que às vezes nem imaginamos, que só pode ser desenvolvido com a confiança e a solidariedade. ${ }^{336}$

O incentivo de Francisco aos atletas está em que eles ponham a sua confiança em Deus e que perseverem no treinamento diário, pois assim sentem-se o que de fato são: parte ativa da sociedade, participando de um encontro para além dos muros da competição, pois que a tecnologia leva os eventos olímpicos para todo o mundo em tempo real.

A Igreja reconhece a dignidade da pessoa com deficiência e luta pela sua inclusão eclesial, mas de fato daria um passo a mais se incluísse no processo formativo a problemática da pessoa com deficiência, primando por uma formação inclusiva, tanto no que diz respeito aos seminários, como o que toca aos agentes pastorais. As pastorais que pretendem acolher as pessoas com deficiência devem ser instruídas sobre suas realidades e devem ter a fé daqueles que levaram o paralítico a Jesus - romper barreiras, estimular as pessoas com deficiência e seus familiares, sair em missão, como pretende Francisco, e ter uma caridade criativa, pois muitas dessas pessoas se encontram em situação que chega a violar a sua própria dignidade.

Inclusão significa ter as mesmas oportunidades respeitando-se à diversidade que, no caso das pessoas com deficiência, seria a princípio reconhecer que todas as pessoas são únicas e irrepetíveis e que cada excluído é uma perda para a

\footnotetext{
${ }^{336}$ FRANCISCO, Discurso aos membros do comitê paraolímpico italiano, 04 de outubro de 2014. Disponível em: <http://w2.vatican.va/content/francesco/pt/speeches/2014/october/documents/papafrancesco_20141004_atleti-paralimpici.html>. Acesso em 12 de agosto de 2015.
} 
comunidade $^{337}$. Nesse sentido Francisco fala em inclusão, mas também em técnicas e programas específicos que tornem possível uma participação expressiva desse grupo de pessoas no Corpo Eclesial.

As pessoas com deficiência são vistas como lugar de reflexão teológica e, em assim sendo, é necessário que se construa uma pedagogia da deficiência, no sentido de que surjam questionamentos que possam alavancar o auxílio a essas pessoas.

\section{Em sua Exortação Pós-Sinodal Amoris Laetitia Francisco se refere às} famílias que tem em seu lar pessoas com deficiência e lhes dá apoio para que continuem a ser exemplo de amor e bondade.

Os Padres dedicaram especial atenção também «às famílias das pessoas com deficiência, já que tal deficiência, ao irromper na vida, gera um desafio profundo e inesperado e transtorna os equilíbrios, os desejos, as expectativas. (...) Merecem grande admiração às famílias que aceitam, com amor, a prova difícil dum filho

\footnotetext{
${ }^{337}$ Francisco diz que todos somos diversos, ninguém é igual a ninguém. Há diversidades maiores e menores, mas, todos somos diversos. (...). A diversidade não diz que quem tem os cinco sentidos funcionando bem seja melhor do que o outro, por exemplo, que o surdo mudo. (...). Ninguém pode ser discriminado. Cada um de nós tem seu modo de conhecer as coisas que é diverso. Um conhece de uma maneira e o outro de outra maneira, mas todos podem conhecer a Deus. (...). Estes irmãos e irmãs não só podem viver uma genuína experiência de encontro com Cristo como podem testemunhá-la aos outros. Muito tem sido feito na pastoral das pessoas com deficiência; é necessário andar adiante reconhecendo a sua capacidade apostólica e missionária e o valor de sua "presença" como pessoa, como membro vivo do Corpo eclesial. Na debilidade e na fragilidade se escondem tesouros capazes de renovar a nossa comunidade cristã. Na Igreja, graças a Deus, se registra uma difusa atenção e acolhimento a pessoa com deficiência seja física, mental ou sensorial. Todavia na nossa comunidade ainda falta a prática uma verdadeira inclusão, uma participação plena que se torne algo normal. E isso requer não só técnica mas a certeza de que cada pessoa é única e irrepetível, e cada um que é excluído significa um empobrecimento da comunidade. Eis o texto: "Tutti siamo diversi: non c'è uno che sia uguale all'altro. Ci sono alcune diversità più grandi o più piccole, ma tutti siamo diversi. (...). La diversità non dice che chi ha $\mathrm{i}$ cinque sensi che funzionano bene sia migliore di chi - per esempio - è sordomuto. (...). Non si può essere discriminati. Ognuno di noi ha un modo di conoscere le cose che è diverso: uno conosce in una maniera, uno conosce in un'altra, ma tutti possono conoscere Dio. (...). Questi fratelli e sorelle - come dimostra anche questo Convegno - non sono soltanto in grado di vivere una genuina esperienza di incontro con Cristo, ma sono anche capaci di testimoniarla agli altri. Molto è stato fatto nella cura pastorale dei disabili; bisogna andare avanti, ad esempio riconoscendo meglio la loro capacità apostolica e missionaria, e prima ancora il valore della loro "presenza" come persone, come membra vive del Corpo ecclesiale. Nella debolezza e nella fragilità si nascondono tesori capaci di rinnovare le nostre comunità cristiane. Nella Chiesa, grazie a Dio, si registra una diffusa attenzione alla disabilità nelle sue forme fisica, mentale e sensoriale, e un atteggiamento di generale accoglienza. Tuttavia le nostre comunità fanno ancora fatica a praticare una vera inclusione, una partecipazione piena che diventi finalmente ordinaria, normale. E questo richiede non solo tecniche e programmi specifici, ma prima di tutto riconoscimento e accoglienza dei volti, tenace e paziente certezza che ogni persona è unica e irripetibile, e ogni volto escluso è un impoverimento della comunità. ( Cf. FRANCISCO, Incontro con i partecipanti al convegno per persone disabili, promosso dalla Conferenza Episcopale Italiana, 11 de junho de 2016. Disponível em: $\quad<$ http://w2.vatican.va/content/francesco/it/speeches/2016/june/documents/papafrancesco_20160611_convegno-disabili.html>.Acesso em 12 de junho de 2016.
} 
deficiente. Dão à Igreja e à sociedade um valioso testemunho de fidelidade ao dom da vida. A família poderá descobrir, juntamente com a comunidade cristã, novos gestos e linguagens, formas de compreensão e identidade, no percurso de acolhimento e cuidado do mistério da fragilidade. As pessoas com deficiência são, para a família, um dom e uma oportunidade para crescer no amor, na ajuda recíproca e na unidade. (...) A família que aceita, com os olhos da fé, a presença de pessoas com deficiência poderá reconhecer e garantir a qualidade e o valor de cada vida, com as suas necessidades, os seus direitos e as suas oportunidades. Tal família providenciará assistência e cuidados e promoverá companhia e carinho em cada fase da vida». Quero sublinhar que a atenção prestada tanto aos migrantes como às pessoas com deficiência é um sinal do Espírito. Pois ambas as situações são paradigmáticas: põem especialmente em questão o modo como se vive, hoje, a lógica do acolhimento misericordioso e da integração das pessoas frágeis. ${ }^{338}$

Ao número de pessoas com deficiência vítimas de guerra e terrorismo somam-se os casos de microcefalia que se alastram tanto no Brasil como no exterior, e infelizmente o que se vê não é a alteridade, a fraternidade ou a misericórdia e sim o desejo de não deixá-las nascer, que, de acordo com o Relatório Final do Sínodo em 2015, é atitude que pode ser interpretada em "chave eugênica".

As pessoas com deficiência constituem para a família um dom e uma oportunidade para crescer no amor, na ajuda recíproca e na unidade. A Igreja, família de Deus, deseja ser casa acolhedora para as famílias com pessoas deficientes (cf. João Paulo II, Homilia por ocasião do Jubileu das Comunidades com Portadores de Deficiência, 3 de dezembro de 2000). Ela colabora para apoiar a sua relação e educação familiar, oferecendo caminhos de participação na vida litúrgica da comunidade. Para diversos deficientes abandonados ou que ficaram sozinhos, as instituições eclesiais de acolhimento muitas vezes são a única família. A elas o Sínodo expressa profunda gratidão e apreço. Este processo de integração torna-se mais difícil naquelas sociedades em que perduram o estigma e o preconceito - até teorizado em chave eugénica. Em contrapartida, muitas famílias, comunidades e movimentos eclesiais descobrem e celebram os dons de Deus nas pessoas com necessidades especiais, particularmente a sua singular capacidade de comunicação e de agregação. Deve-se dedicar especial atenção às pessoas deficientes que sobrevivem aos seus pais e à família mais ampla que os apoiou ao longo da vida. A morte daqueles pelos quais foram amados e que eles amaram torna-os particularmente vulneráveis. A família que aceita com o olhar da fé a presença de pessoas com deficiência poderá reconhecer e garantir a qualidade e o valor de cada vida, com as suas necessidades, os seus direitos e as suas oportunidades. Ela solicitará serviços e cuidados, e promoverá companhia e afeto, em cada fase da vida. ${ }^{339}$

\footnotetext{
${ }^{338}$ AL 47.

339 FRANCISCO, A vocação e a missão da família na Igreja e no mundo contemporâneo. Relatório final do Sínodo dos Bispos ao Santo Padre Francisco. Pessoas com necessidades especiais, 26 de outubro de 2014. Disponível em: <http://www.vatican.va/roman_curia/synod/documents/rc_synod_doc_20151026_relazione-finalexiv-assemblea_po.html\#Pessoas_com_necessidades_especiais> Acesso em_03 de março de 2016.
} 
Francisco aponta de forma contundente para esse quadro de descarte e indiferença em seus discursos que destacam o descarte em relação aos mais frágeis.

Como é possível não ver, em tudo isto, o resultado daquela «cultura do descarte» que põe em perigo a pessoa humana, sacrificando homens e mulheres aos ídolos do lucro e do consumo? É grave habituar-se a estas situações de pobreza e necessidade, aos dramas de tantas pessoas, fazendo com que se tornem «normalidade». As pessoas já não são vistas como um valor primário a respeitar e tutelar, especialmente se são pobres ou deficientes, se «ainda não servem» (como os nascituros) ou «já não servem» (como os idosos). ${ }^{340}$

Esses fatos tornam preocupante o quadro que pouco a pouco se cristaliza em relação às pessoas com deficiência, pois muitas pessoas se tornaram e se tornarão pessoas com deficiência, em razão da violência do mundo atual. Por outro lado, é dramático constatar que a população queira eliminar pessoas com deficiência, como nos casos dos anencéfalos e dos microcéfalos.

Nenhuma pessoa jamais pode ser segregada e não se pode ter uma visão parcial do homem em razão de sua deficiência. Urge eliminar toda a forma de hostilidade e preconceito, posto que nenhum grupo pode ser deixado à deriva, à margem da sociedade.

O fato de não haver relativismo nas diferenças, ou seja, o fato de que todos os homens sejam absolutamente diferentes, já indica que a pessoa com deficiência ao nascer, está regularmente inserida no contexto e na estrutura do organismo social, pois sua composição implica desigualdade. Por outro lado, há uma igualdade impactante que é a limitação humana.

Essa é a realidade da limitação ${ }^{341}$ que não permite ao homem ter uma visão correta do que seja o sentido da vida. Uma vez que todos partilham a mesma realidade de limitação, todos de algum modo estão carentes ou deficientes de alguma coisa, e então, como é possível segregar o irmão?

Diante de todo o exposto se conclui que Francisco está disposto a promover a cultura do encontro e para isso deseja e aposta em um engajamento de todos,

\footnotetext{
340 FRANCISCO, Discurso ao Corpo Diplomático acreditado junto a Santa Sé para as felicitações de bons votos, 11 de janeiro de 2016. Disponível em: <http://w2.vatican.va/content/francesco/pt/speeches/2016/january/documents/papafrancesco_20160111_corpo-diplomatico.html>. Acesso em 12 de maio de 2016.

${ }^{341}$ FRANCISCO, Jubileu dos doentes e das pessoas portadoras de deficiência, 12 de junho de 2016.
} 
para que no âmbito de uma fraternidade mística, cada qual a seu modo, se comprometa a lutar para, se possível, erradicar definitivamente a cultura do descarte e da exclusão.

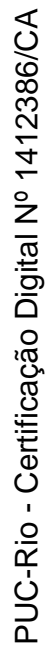




\section{5 \\ Conclusão}

Plasma-se o entendimento de que havia, e continua havendo, a necessidade de uma exortação internacional no sentido de que se faça respeitar as pessoas com deficiência posto que sua dignidade e sua vida são, como a de todos os seres humanos - inalienáveis - em uma sociedade em que a vida parece ser coisa de segunda importância, face ao descaso em relação a ela e à medida que se lhe dá, relegada apenas e tão somente ao valor utilitário.

Assim sendo, é mister promover a dignidade humana da pessoa com deficiência para que não haja uma sensação de alijamento social, face à discriminação, sensação que está para além da subjetividade, vez que o preconceito é real. Diante de uma pessoa com deficiência física ou motora, sensorial ou mental, as pessoas vivem sentimentos contraditórios, desde a repulsa até a compaixão.

Exatamente por isso, a postura de Francisco é expressiva nesse contexto, pois o Bispo de Roma trouxe para o centro da discussão um feroz ataque em relação ao que ele chama de "cultura do descarte", que abre seus sustentáculos rumo à indiferença. Em uma inversão do que vem a ser o objeto do "descarte", Francisco joga no lixo o egoísmo e o individualismo que permeiam de forma expressiva as relações sociais.

Nesse sentido o primeiro capítulo apresentou Francisco e aquilo que vem a ser a sua doutrina teológico-espiritual que está em continuidade com seu Ministério em Buenos Aires. Assim, como ele gosta de dizer, o "caminho" está sendo percorrido; um caminho que já em seu Arcebispado se preocupa com a defesa dos mais simples, baseando-se no valor da dignidade humana, na alteridade e na fraternidade. A opção preferencial pelos pobres quer garantir a esses que são os mais frágeis, vulneráveis e excluídos, a possibilidade de fazer a própria história sem paternalismos.

O segundo capítulo refletiu a fundamentação doutrinária de Francisco em relação à misericórdia. Nesse capítulo se uniu o fundamento espiritual e o fundamento pastoral que perpassam toda a doutrina de Francisco, pois só se pode 
amar e guardar o irmão menos favorecido defendendo sua vida de forma contundente, fraterna e solidária, quando se está voltado para o amor de Deus que se expressa não somente, mas também, em Sua misericórdia.

Sair em direção às periferias geográficas e existenciais evidencia essa misericórdia em ato, pois Francisco pede aos fiéis que não sejam portadores de discursos bonitos apenas, mas também de atitudes concretas em nome desses que são os descartados, aqueles pelos quais a sociedade não nutre uma ativa solidariedade. Aliás, diz Francisco, essa palavra parece até um palavrão em face de tanto descaso e indiferença com os irmãos que deveriam ser objeto de cuidado por parte de todos, pois afinal somos todos guardas de nossos irmãos.

Um extenso elenco compõe o rol de excluídos, oprimidos e abandonados, mas, na contramão do mundo que os exclui, está a Igreja de Francisco que os erige a qualidade de categoria teologal, pois sua Igreja não é somente misericordiosa; ela é uma Igreja pobre para os pobres.

Os desvalidos se apresentam na pessoa dos nascituros abortados, das crianças, dos jovens, dos velhos, dos enfermos, das pessoas com deficiência

No terceiro capítulo veio à tona o chamado de Francisco para que olhemos com amor para esses nossos irmãos mais vulneráveis, especialmente as pessoas com deficiência, pois essas pessoas são recursos de riqueza para a humanidade, sendo portadoras de uma fortaleza de ânimo que nos educa na fé.

O testemunho de três pessoas tão distintas entre si veio comprovar que conviver com pessoas com deficiência é razão de elevação espiritual e conversão amorosa.

Efetivamente essa dissertação é apenas um recorte na doutrina teológico-pastoral de Francisco, doutrina essa que abrange outros tópicos de valor

expressivo, como por exemplo, a participação das mulheres na Igreja, quiçá diaconisas; os problemas econômicos, políticos e éticos enfrentados pelas sociedades; o ecumenismo e o diálogo inter-religioso; a questão migratória; a renovação e conversão eclesial, o meio-ambiente, a paz no mundo, a família e outros tantos assuntos que não foram objeto dessa dissertação.

Entretanto, ao dispor sobre a pessoa de Francisco como aquele que capta os desejos do mundo e os exprime para todos os povos e nações, no sentido de alavancar e expressar essas vontades de forma densa e amplificada, é possível dizer que se abre um amplo universo de pesquisa, pois os pontos que tocam a 
doutrina de Francisco, como os acima expostos, podem ser aquilatados com a mesma medida que foi dada a questão das pessoas com deficiência.

Em outras palavras o que se quer dizer é que Francisco "passeia" pelo mundo cultural a partir da "leitura" dos corações humanos e consegue expressar essa "leitura" de maneira a introduzi-la no mundo cultural, embora, no mais das vezes, seu universo seja a via eclesial, teológica e pastoral. Por outro lado, aquilo que essas culturas têm de positivo pode ser albergado e direcionado para a promoção da "cultura do encontro", um dos carros chefes de seu Pontificado.

Por tudo isso, Francisco nos leva a concluir que, apesar de tudo, as pessoas pobres e também as pessoas que sofrem com deficiência são de fato aquelas que são as mais felizes, pois foram essas pessoas as mais felizes que ao longo da vida Francisco encontrou; um paradoxo para muitos, mas bem de acordo com as BemAventuranças proclamadas por Jesus Cristo, pois todos aqueles que são os bemaventurados no Reino dos Céus estão na contramão do mundo. 


\section{Referências Bibliográficas}

AGENCIA INFORMATIVA CATOLICA ARGENTINA, BERGOGLIO, J. M., Comunicado del Card. Bergoglio sobre la resolución para abortos no punibles, 10 SETEMBRO 2012. Disponível em: <http://www.aica.org/3161-comunicadodel-card-bergoglio-sobre-la-resolucion-para-abortos-no.html>. Acesso em 08.02.2016).

BERGOGLIO J. M., Homilía del Arzobispo de Buenos Aires en la Misa de Clausura del Congreso Nacional de Doctrina Social de la Iglesia, 8 de maio de 2011. <http://www.arzbaires.org.ar/inicio/homiliasbergoglio.html>. Acesso em 14 de maio de 2016).

Propuesta de Aparecida para la Pastoral de la Iglesia en Argentina, 15 de junho de $2009 . \quad$ Disponível em: <http://www. www.arzbaires.org.ar/inicio/homiliasbergoglio.html>. Acesso em 25 de maio de 2016).

__ Encuentro de políticos y lesgiladores de América Latina, 03 de agosto de $1999 . \quad$ Disponível em: <http://www.arzbaires.org.ar/inicio/homiliasbergoglio.html>. Acesso em 29 de maio de 2016).

, Mensaje Cuaresmal del Sr. Arzobispo. A los sacerdotes, consagrados y laicos de la Arquidiócesis, 13 de fevereiro de 2013. Disponível em: <http://www.arzbaires.org.ar/inicio/homiliasbergoglio.html>. Acesso em $24 \mathrm{de}$ maio de 2016).

Palabras Iniciales Del Sr. Arzobispo En El Primer Congreso Regional De Pastoral Urbana Dios Vive En La Ciudad, Buenos Aires, 25 de agosto de 2011. Disponível em: <http://www.arzbaires.org.ar/inicio/homiliasbergoglio.html>. Acesso em 25 de maio de 2016).

Caminhando para a maturidade. Reflexões sobre a família e a educação. São Paulo: Ecclesiae, 2014, ebook Kindle.

Desgrabación de la homilía del Cardenal Jorge Mario Bergoglio s.j. en ocasión de la misa de clausura del Encuentro 2012 de Pastoral Urbana Región Buenos Aires, 02 de setembro de 2012. Disponível em: <http://www.arzbaires.org.ar/inicio/homiliasbergoglio.html>. Acesso em 29 de maio de 2016).

Escute o clamor do seu povo. São Paulo: Ave-Maria, Edição digital ebookKindle, agosto 2014.

Homilía en la Misa de Apertura de $94^{a}$ Asamblea Plenaria, 05 de novembro de 2007. Disponível em: 
<http://www.arzbaires.org.ar/inicio/homiliasbergoglio.html>. Acesso em $23 \mathrm{de}$ maio de 2016.

_, Mente aberta, coração que crê. São Paulo: Ave-Maria, 2013, pp. 206-207.

, O Verdadeiro poder é o serviço. São Paulo: Ave-Maria, 2013.

— SKORKA, A., FIGUEIROA. M., A solidariedade. São Paulo: Benvirá, 2013.

, SKORKA, A., Sobre o céu e a terra. São Paulo: Editora Paralela, 2013.

Só o amor nos salvará. Portugal: Editora Princípia, 2013.

BOFF, L., Carta de apoio ao Papa Francisco. 07 de novembro de 2015. In leonardoBOFF.com. Disponível em: $<$ https://leonardoboff.wordpress.com/2015/11/07/carta-de-apoio-ao-papafrancisco/> . Acesso em 20 de junho de 2016.

, O Papa Francisco, chamado a restaurar a Igreja, 14.03.2013. In Brasil de fato. Disponível em: <http://antigo.brasildefato.com.br/node/12324>. Acesso em 17 de junho de 2016.

Francisco de Assis e Francisco de Roma. In Mar de ideias e navegação cultural, 18 de novembro de 2014. Disponível em: $<$ https://www.youtube.com/watch?v=w2tfM-5T6z4>. Acesso em 17 de junho de 2016.

BOSCH M. D., Uma entrevista exclusiva da Aleteia com um homem extraordinário, que vive e trabalha com "gente de coração. Jean Vanier fundador da L'Arche "os mais rejeitados nos levam a Deus".19 de abril de 2016. In: Aleteia. Disponível em: http://pt.aleteia.org/2016/04/19/jean-vanier-fundador-dalarche-os-mais-rejeitados-nos-levam-a-deus/. Acesso em 24 de junho de 2016.

BUSOLINI D. Entrevista com Jean Vanier. L'Anno Santo nelle parole di Jean Vanier, fondatore dell" "Arca" e di "Fede e Luce". La testimonianza di fede delle persone con handicap, "maestre di umanità". "Un anno speciale per ricevere il dono di Gesù". Disponível em: <http://www.vatican.va/jubilee_2000/pilgrim/documents/ju_gp_07032000_p8a_it.html>.Acesso em 25 de junho de 2016

BYINGTON O. O que é que ele tem. Rio de Janeiro: Objetiva, EbookKindle, 2016.

CODINA V., A pastoral do abraço do Papa Francisco. In: Unisinos. 21 de julho de 2015 Disponível em: <http://www.ihu.unisinos.br/noticias/544803-a-pastoraldo-abraco-do-papa-francisco>. Acesso em 22 de novembro de 2015). 
Disponível em: <http://www.arzbaires.org.ar/inicio/homiliasbergoglio.html>. Acesso em 14 de maio de 2016).

FRANCISCO, Angelus, 16 de novembro de 2014. Disponível em: <http://m2.vatican.va/content/francesco/pt/angelus/2014/documents/papafrancesco_angelus_20141116.html>. Acesso em 01 de julho de 2016.

Angelus, 7 de dezembro de 2014. Disponível em: <https://w2.vatican.va/content/francesco/pt/angelus/2014/documents/papafrancesco_angelus_20141207.html>. Acesso em 03 de julho de 2016

, Angelus, 14 de julho de 2013. Disponível em: <http://w2.vatican.va/content/francesco/pt/angelus/2013/documents/papafrancesco_angelus_20130714.html>.Acesso em 03 de julho de 2016.

_ A delegação da associação internacional de direito penal, 23 de outubro de 2014. Disponível em: <http://w2.vatican.va/content/francesco/pt/speeches/2014/october/documents/papa -francesco_20141023_associazione-internazionale-diritto-penale.html>. Acesso em 20 de abril de 2015.

, A verdade é um encontro. São Paulo: Paulinas, 2015.

A vocação e a missão da família na Igreja e no mundo contemporâneo. Relatório final do Sínodo dos Bispos ao Santo Padre Francisco. Pessoas com necessidades especiais, 26 de outubro de 2014. Disponível em: <http://www.vatican.va/roman_curia/synod/documents/rc_synod_doc_20151026_ relazione-finale-xiv-assemblea_po.html\#Pessoas_com_necessidades_especiais> Acesso em _03 de março de 2016.

Angelus, 09 de fevereiro de 2014. Disponível em: <http://w2.vatican.va/content/francesco/pt/angelus/2014/documents/papafrancesco_angelus_20140209.html>. Acesso em 04 de julho de 2016.

Angelus, 10 de Novembro de 2013. Disponível em: <http://w2.vatican.va/content/francesco/pt/angelus/2013/documents/papafrancesco_angelus_20131110.html>. Acesso em 04 de julho de 2016.

, Angelus, 17 de março de 2013. Disponível em:

<http://w2.vatican.va/content/francesco/pt/angelus/2013/documents/papafrancesco_angelus_20130317.html>. Acesso em 04 de julho de 2016.

Angelus, 21 de julho de 2013. Disponível em: $<$ http://w2.vatican.va/content/francesco/pt/angelus/2013/documents/papafrancesco_angelus_20130721.html>. Acesso em 30 de junho de 2016.

Aos participantes no Congresso da Associação dos médicos católicos italianos, 15 de novembro de 2014. Disponível em: 
<http://w2.vatican.va/content/francesco/pt/speeches/2014/november/documents/p apa-francesco_20141115_medici-cattolici-italiani.html>. Acesso em 03 de fevereiro de 2016.

Aos participantes no Congresso da Sociedade de Cirurgia Oncológica promovido pela Universidade "La Sapienza” de Roma, 12 de abril de 2014.

Disponível

em:

<http://w2.vatican.va/content/francesco/pt/speeches/2014/april/documents/papa-

francesco_20140412_congresso-chirurgia-oncologica.html>. Acesso em 02 de abril de 2015).

Audiência Geral, 10 de setembro de 2014. Disponível em: <http://w2.vatican.va/content/francesco/pt/audiences/2014/documents/papafrancesco_20140910_udienza-generale.html>. Acesso em 2 de junho de 2016.

Audiência Geral, 10 de setembro de 2014. Disponível em: <http://w2.vatican.va/content/francesco/pt/audiences/2014/documents/papafrancesco_20140910_udienza-generale.html >. Acesso em 10 de julho de 2016

Audiência Geral, 11 de junho de 2014. Disponível em: $<$ https://w2.vatican.va/content/francesco/pt/audiences/2014/documents/papafrancesco_20140611_udienza-generale.html>. Acesso em 03 de julho de 2016

,Biografia.

Disponível

em: <https://w2.vatican.va/content/francesco/pt/biography/documents/papa-francescobiografia-bergoglio.html>. Acesso em 01 de julho de 2016.

2015.

Bula Misericordiae Vultus. O rosto da misericórdia. São Paulo: Paulus,

, Carta Encíclica Laudato Si. São Paulo, Paulinas, 2015.

,Carta Encíclica Lumen Fidei. São Paulo, Paulus, 2013.

, Conferência de imprensa no voo de Manila a Roma, 19 de janeiro de $2015 . \quad$ Disponível em: $<$ http://w2.vatican.va/content/francesco/pt/speeches/2015/january/documents/papa -francesco_20150119_srilanka-filippine-conferenza-stampa.html>. Acesso em 03.072016.

Cristãos disfarçados, 20 de março de 2014. Disponível em: <http://w2.vatican.va/content/francesco/pt/cotidie/2014/documents/papafrancesco_20140320_meditazioni-41.html>. Acesso em 1 de julho de 2016.

Diálogo com os alunos dos Pontifícios Colégios e Internatos de Roma, 12 de maio de 2014. Disponível em: <http://w2.vatican.va/content/francesco/pt/speeches/2014/may/documents/papa- 
francesco_20140512_pontifici-collegi-convitti.html>. Acesso em 20 de julho de 2015 .

Discurso aos sócios do círculo de São Pedro, 31 de outubro de 2013. Disponível

em:<http://w2.vatican.va/content/francesco/pt/speeches/2013/october/documents/ papa-francesco_20131031_circolo-san-pietro.html>. Acesso em 29 de junho de 2016.

, Discurso a los participantes em la Plenaria de la Congregación para las Iglesias Orientales, 21 de novembro de 2013. Disponível em: <https://w2.vatican.va/content/francesco/es/speeches/2013/november/documents/ papa-francesco_20131121_plenaria-congreg-chiese-orientali.html>. Acesso em 03 de fevereiro de 2016).

Discurso ao Conselho Nacional da União Italiana dos cegos e deficientes visuais por ocasião da festa de Santa Luzia, 13 de dezembro de 2014. Disponível em:

$<$ https://w2.vatican.va/content/francesco/pt/speeches/2014/december/documents/p apa-francesco_20141213_unione-ciechi-ipovedenti.html >. Acesso em 14 de setembro de 2015.

, Discurso ao Corpo Diplomático acreditado junto a Santa Sé, 13 de janeiro de $2014 . \quad$ Disponível em: <http://w2.vatican.va/content/francesco/pt/speeches/2014/january/documents/papa -francesco_20140113_corpo>. Acesso em 19 de setembro de 2015.

Discurso ao Corpo Diplomático acreditado junto a Santa Sé para as felicitações de bons votos, 11 de janeiro de 2016. Disponível em: <http://w2.vatican.va/content/francesco/pt/speeches/2016/january/documents/papa -francesco_20160111_corpo-diplomatico.html>. Acesso em 12 de maio de 2016.

, Discurso ao Movimento Apostólico de Cegos (MAC) e à Pequena Missão para os Surdos-Mudos, 29 de março de 2014. Disponível em: <http://w2.vatican.va/content/francesco/pt/speeches/2014/march/documents/papafrancesco_20140329_movimento-ciechi-missione-sordomuti.html>. Acesso em 22 de novembro de 2014.

Discurso aos Bispos da Conferência Episcopal de Timor Leste em Visita "Ad Limina Apostolorum", 17 de março de 2014. Disponível em: $<$ http://w2.vatican.va/content/francesco/pt/speeches/2014/march/documents/papafrancesco_20140317_ad-limina-timor-est.html>. Acesso em 29 de junho de 2016.

, Discurso aos catequistas vindos a Roma em peregrinação por ocasião do Ano da Fé e do Congresso Internacional de Catequese, 27 de setembro de $2013 . \quad$ Disponível em: <http://w2.vatican.va/content/francesco/pt/speeches/2013/september/documents/p apa-francesco_20130927_pellegrinaggio-catechisti.html>. Acesso em 29 de junho de 2016. 
2014. Discurso aos membros do comitê paraolímpico italiano, 04 de outubro de
Disponível <http://w2.vatican.va/content/francesco/pt/speeches/2014/october/documents/papa -francesco_20141004_atleti-paralimpici.html>. Acesso em 12 de agosto de 2015.

, Discurso aos membros do Corpo Diplomático acreditado junto a Santa Sé, 13 de janeiro de 2014. Disponível em: $<$ https://w2.vatican.va/content/francesco/pt/speeches/2014/january/documents/pap a-francesco_20140113_corpo-diplomatico.html>. Acesso em 27 de julho de 2015.

Discurso aos membros do Corpo Diplomático Acreditado junto a Santa Sé, 12 de janeiro de 2015. Disponível em: <http://w2.vatican.va/content/francesco/pt/speeches/2015/january/documents/papa -francesco_20150112_corpo-diplomatico.html>. Acesso em 04 de fevereiro de 2016.

Discurso aos membros do Instituto Dignitatis Humanae, 07 de dezembro de 2013. Disponível em: <http://m2.vatican.va/content/francesco/pt/speeches/2013/december/documents/pa pa-francesco_20131207_istituto-dignitatis.html>. Acesso em 28 de maio de 2015.

, Discurso aos membros do instituto Dignitatis Humanae, 07 de dezembro de 2013. Disponível em: $<$ http://m2.vatican.va/content/francesco/pt/speeches/2013/december/documents/pa pa-francesco_20131207_istituto-dignitatis.html>. Acesso em 28 de maio de 2015.

Discurso aos novos embaixadores junto da Santa Sé por ocasião da apresentação das cartas credenciais, 12 de dezembro de 2013. Disponível em: <http://w2.vatican.va/content/francesco/pt/speeches/2013/december/documents/pa pa-francesco_20131212_credenziali-nuovi-ambasciatori.html $>$. Acesso em $22 \mathrm{de}$ julho de 2015 .

Disponível

Discurso aos párocos da Diocese de Roma, 06 de março de 2014. <https//w2 vatican va/content/francesco/pt/speeches/2014/march/documents/papa -francesco_20140306_clero-diocesi-roma.html>. Acesso em 22 de abril de 2015.

Disponível

Discurso aos párocos da Diocese de Roma, 6 de março de 2014. <http://w2.vatican.va/content/francesco/pt/speeches/2014/march/documents/papafrancesco_20140306_clero-diocesi-roma.html>. Acesso em 03 de julho de 2016.

Discurso aos participantes na sessão plenária do Pontifício Conselho para a Pastoral no campo da saúde, 24 de março de 2014. Disponível em: $<$ http://m2.vatican.va/content/francescomobile/pt/speeches/2014/march/document s/papa-francesco_20140324_plenaria-operatori-sanitari.html>. Acesso em $14 \mathrm{de}$ julho de 2015. 
Discurso aos participantes no $37^{\circ}$ encontro nacional da renovação carismática católica, 01 de junho de 2014. Disponível em: <http://w2.vatican.va/content/francesco/pt/speeches/2014/june/documents/papafrancesco_20140601_rinnovamento-spirito-santo.html >). Acesso em 22 de junho de 2015 .

— Discurso aos participantes no Congresso para pessoas deficientes promovido pela Conferência Episcopal Italiana, 11de junho de 2016. Disponível em: $<$ https://w2.vatican.va/content/francesco/pt/speeches/2016/june/documents/papafrancesco_20160611_convegno-disabili.html>. Acesso em 24 de junho de 2016.

Discurso às associações dos Operários Silenciosos da Cruz e Centro de Voluntários do Sofrimento fundadas pelo beato Luigi Novarese, 17 de maio de $2014 . \quad$ Disponível em: <http://w2.vatican.va/content/francesco/pt/speeches/2014/may/documents/papafrancesco_20140517_operai-croce-volontari-sofferenza.html $>$. Acesso em 23 de junho de 2016.

, Discurso às Misericórdias da Itália e aos grupos $<\langle$ Fratres $\rangle>$ no $30^{\circ}$ aniversário da Audiência com o Papa João Paulo II, 14 de junho de 2014. Disponível

em: $<$ https://w2.vatican.va/content/francesco/pt/speeches/2014/june/documents/papafrancesco_20140614_confederaz-misericordie-d-italia.html >. Acesso em 28 de maio de 2015

, Discurso às participantes no Capítulo Geral das filhas de Maria Auxiliadora, 08 de novembro de 2014. Disponível em: <https://w2.vatican.va/content/francesco/pt/speeches/2014/november/documents/p apa-francesco_20141108_figlie-maria-ausiliatrice.pdf $>$. Acesso em 01 de julho de 2016.

, Discurso às religiosas participantes na Assembleia Plenária da União Internacional das Superioras-gerais, 08 de maio de 2013. Disponível em:

<http://w2.vatican.va/content/francesco/pt/speeches/2013/may/documents/papafrancesco_20130508_uisg.html>. Acesso em 04 de julho de 2016.

Discurso à Associação Nacional das famílias numerosas, 28 de dezembro de 2014. Disponível em: <http://w2.vatican.va/content/francesco/pt/speeches/2014/december/documents/pa pa-francesco_20141228_famiglie-numerose.html>. Acesso em 04 de julho de 2016.

Disponível

Encontro com a classe dirigente do Brasil, 27 de julho de 2013. <https://w2.vatican.va/content/francesco/pt/speeches/2013/july/documents/papafrancesco_20130727_gmg-classe-dirigente-rio.html>. Acesso em 25 de maio de 2015. 
, Encontro com as crianças com deficiências e os doentes do Instituto Seráfico. 04 de outubro de 2013, Disponível em: <http://w2.vatican.va/content/francesco/pt/speeches/2013/october/documents/papa -francesco_20131004_bambini-assisi.html>. Acesso em 25 de agosto de 2015.

2013. Encontro com as crianças deficientes - visita pastoral, 04 de outubro de $<\mathrm{http}$ ///w2.vatican.va/content/francescomobile/pt/speeches/2013/october/documen ts/papa-francesco_20131004_bambini-assisi.html >. Acesso em 22 de junho de 2015.

Encontro com o Clero, os consagrados e os membros dos pastorais, 04 de outubro de 2013. Disponível em: <http://w2.vatican.va/content/francesco/pt/speeches/2013/october/documents/papa -francesco_20131004_clero-assisi.html>. Acesso em 29 de junho de 2016.

, Encontro com o Episcopado Brasileiro em 27 de julho de 2013.

Disponível

em:

<http://w2.vatican.va/content/francesco/pt/speeches/2013/july/documents/papafrancesco_20130727_gmg-episcopato-brasile.html>. Acesso em 28 de maio de 2015.

, Encontro com os cidadãos e proclamação do ano jubilar celestiano, 05 de julho de 2014. Disponível <http://w2.vatican.va/content/francesco/pt/speeches/2014/july/documents/papafrancesco_20140705_molise-indizione-anno-celestiniano.html >. Acesso em $30 \mathrm{de}$ junho de 2016

, Encontro com os jornalistas durante o voo para Manila, 15 de Janeiro de $2015 . \quad$ Disponível em: $<$ http://w2.vatican.va/content/francesco/pt/speeches/2015/january/documents/papa -francesco_20150115_srilanka-filippine-incontro-giornalisti.html>. Acesso em 03 de julho de 2016).

Encontro com os jornalistas durante o voo de regresso da Coreia a Roma, 18 de agosto de 2014. Disponível em:

$<\mathrm{http}$ ///w2.vatican.va/content/francesco/pt/speeches/2014/august/documents/papafrancesco_20140818_corea-conferenza-stampa.html>. Acesso em 30 de maio de 2016.

Encontro com os representantes dos Meios de Comunicação Social, 16 de março de 2013.2 Disponível em: <http://w2.vatican.va/content/francesco/pt/speeches/2013/march/documents/papafrancesco_20130316_rappresentanti-media.html>. Acesso em 24 de abril de 2015.

2013. Entrevista ao Papa Francisco. Pe. Antonio Spadaro, 21 de setembro de <http://w2.vatican.va/content/francesco/pt/speeches/2013/september/documents/p 
apa-francesco_20130921_intervista-spadaro.html>. Acesso em 26 de maio de 2015. 2016 .

ExortaçãoApóstólica Pós-Sinodal Amoris Laetitia. São Paulo: Paulus,

Exortação Apostólica Evangelii Gaudium. São Paulo: Paulus, 2013

- Homilia Do Santo Padre. II Domingo de Páscoa ou da Divina Misericórdia, 7 de abril de 2013. Disponível em: <http://w2.vatican.va/content/francesco/pt/homilies/2013/documents/papafrancesco_20130407_omelia-possesso-cattedra-laterano.html>. Acesso em $04 \mathrm{de}$ julho de 2016.

, Homilia, V Domingo de Quaresma, 17 de Março de 2013. Disponível em: <http://w2.vatican.va/content/francesco/pt/homilies/2013/documents/papafrancesco_20130317_omelia-santa-anna.html>. Acesso em 03 de julho de 2016.

Incontro con i partecipanti al convegno per persone disabili, promosso dalla Conferenza Episcopale Italiana, 11 de junho de 2016. Disponível em: $<$ http://w2.vatican.va/content/francesco/it/speeches/2016/june/documents/papafrancesco_20160611_convegno-disabili.html>.Acesso em 12 de junho de 2016.

, Jesus sempre nos espera. Brasília: Edições CNBB, 2014.

em: , JMJ Visita a comunidade de Varginha, 25 de julho de 2013. Disponível $<$ http://w2.vatican.va/content/francesco/pt/speeches/2013/july/documents/papafrancesco_20130725_gmg-comunita-varginha.html>. Acesso em 2 de julho de 2015.

Jubileu Extraordinário da Misericórdia. Jubileu da Divina Misericórdia, 03 de abril de 2016. Disponível em: $<$ https://w2.vatican.va/content/francesco/pt/homilies/2016/documents/papafrancesco_20160403_omelia-giubileo-divina-misericordia.pdf $>$. Acesso em $01 \mathrm{de}$ julho de 2016.

, Jubileu Extraordinário da Misericórdia. Jubileu dos doentes e das pessoas portadoras de deficiência, 12 de junho de 2016. Disponível em: $<$ https://w2.vatican.va/content/francesco/pt/homilies/2016/documents/papafrancesco_20160612_omelia-giubileo-ammalati-disabili.html>. Acesso em 26 de junho de 2016 .

, Jubileu Extraordinário da Misericórdia. Jubileu dos Sacerdotes, 03 de junho de 2016.2 Disponível em: <http://w2.vatican.va/content/francesco/pt/homilies/2016/documents/papafrancesco_20160603_omelia-giubileo-sacerdoti.html>. Acesso em 02 de julho de 2016. 
- Meditações matutinas na Santa Missa celebrada na capela da Domus

Sanctae Marthae. Quando o ódio mata. 12 de junho de 2014. Disponível em: $<$ http://w2.vatican.va/content/francesco/pt/cotidie/2014/documents/papa-

francesco_20140612_meditazioni-69.html>. Acesso em 22 de junho de 2015.

, Meditações matutinas na Santa Missa celebrada

na capela da casa Santa Marta. Perdão numa caricia, 07 de abril de 2014.

Disponível em:

<https://w2.vatican.va/content/francesco/pt/cotidie/2014/documents/papa-

francesco_20140407_meditazioni-46.html>. Acesso em 29 de junho de 2016.

\section{Meditações matutinas na Santa Missa celebrada}

na capela da casa Santa Marta. Carícia de pai, 10 de dezembro de 2015. Disponível

em:

$<$ http://w2.vatican.va/content/francesco/pt/cotidie/2015/documents/papa-

francesco-cotidie_20151210_caricia-de-pai.html>. Acesso em 04 de julho de 2015.

Meditações matutinas na Santa Missa celebrada

na capela da casa Santa Marta. A nossa esperança nas mãos seguras de Deus, 14 de novembro de 2013. Disponível em: <http://w2.vatican.va/content/francesco/pt/cotidie/2013/documents/papafrancesco_20131114_meditazioni-25.html>. Acesso em 30 de junho de 2016.

Meditações matutinas na Santa Missa celebrada na capela da casa Santa Marta. A canção de embalar de Deus,. 27 de Junho de 2014.

Disponível

em: http://w2.vatican.va/content/francesco/pt/cotidie/2014/documents/papafrancesco_20140627_meditazioni-77.html. Acesso em 29 de junho de 2016.

, Mensagem Áudio aos Sócios da União Italiana de cegos e a todos os deficientes visuais, 11 de junho de 2013. Disponível em: $<$ https://w2.vatican.va/content/francesco/pt/messages/pontmessages/2013/documents/papa-francesco_20130611_audiomessaggiociechi.html>. Acesso em 11 de novembro de 2014.

Mensagem de vídeo aos participantes na peregrinação-encontro no Santuário dedicado a Nossa Senhora de Guadalupe na cidade do México, 16 de novembro de 2013. Disponível em: $<$ http://w2.vatican.va/content/francesco/pt/messages/pontmessages/2013/documents/papa-francesco_20131116_videomessaggioguadalupe.html>. Acesso em 04 de julho de 2016.

, Mensagem para a celebração do XLVIII Dia Mundial da Paz, 08 de dezembro de 2014. Disponível em: <http://w2.vatican.va/content/francesco/pt/messages/peace/documents/papafrancesco_20141208_messaggio-xlviii-giornata-mondiale-pace-2015.html>. Acesso em 22 de maio de 2015. 
, Mensagem para a celebração do XLVII Dia Mundial da Paz, $1^{\circ}$ de janeiro de 2014. Disponível em: $<$ http://w2.vatican.va/content/francesco/pt/messages/peace/documents/papafrancesco_20131208_messaggio-xlvii-giornata-mondiale-pace-2014.html>. Acesso em 03 de julho de 2016.

$\begin{array}{cccc}\text {, Mensagem para o XLIX Dia Mundial das Comunicações Sociais, } 23 \mathrm{de} \\ \text { janeiro } & \text { de } & \text { Disponível }\end{array}$ <http://w2.vatican.va/content/francesco/pt/messages/communications/documents/ papa-francesco_20150123_messaggio-comunicazioni-sociali.html>. Acesso em 14 de agosto de 2015 .

2014. Mensagem para o XXIII dia Mundial do Doente,2015, 03 de dezembro de
Disponível <http://w2.vatican.va/content/francesco/pt/messages/sick/documents/papafrancesco_20141203_giornata-malato.html>. Acesso em 29 de junho de 2016.

, Mensagem por ocasião do I Congresso Latino-Americano de pastoral familiar que se celebra de 4 a 9 de agosto na cidade do Panamá, 08 de agosto de 2014.2 Disponível em: $<$ http://w2.vatican.va/content/francesco/pt/messages/pontmessages/2014/documents/papa-francesco_20140508_messaggio-i-congressocelam-pastorale-familiare.html>. Acesso em 01 de julho de 2016.

, Mensagem por ocasião do XXXV meeting para a amizade entre os povos, 23 de agosto de 2014. Disponível em: $<$ http://w2.vatican.va/content/francesco/pt/messages/pontmessages/2014/documents/papa-francesco_20140823_messaggio-meetingamicizia-popoli.html>.Acesso em 03 de julho de 2016.

, Mensagem Urbi et Orbi Natal 2013, 25 de dezembro de 2013. Disponível em : <http://w2.vatican.va/content/francesco/pt/messages/urbi/documents/papafrancesco_20131225_urbi-et-orbi-natale.html>. Acesso em 29 de junho de 2016.

, Mensagem vídeo por ocasião da abertura do ano da vida consagrada na Basílica de Santa Maria Maior, 29 de novembro de 2014. Disponível em: $<$ http://w2.vatican.va/content/francesco/pt/messages/pontmessages/2014/documents/papa-francesco_20141129_video-messaggio-vitaconsacrata.html>. Acesso 30 de junho de 2016.

, Mensagem ao cardeal Kurt Koch por ocasião da $10^{a}$ Assembleia Geral do Conselho Ecuménico das Igrejas, 04 de outubro de 2013. Disponível em: $<$ http://w2.vatican.va/content/francesco/pt/messages/pontmessages/2013/documents/papa-francesco_20131004_world-councilchurches.html>. Acesso em 30 de junho de 2016.

Misas matutinas en la capilla de la domus Sanctae Marthae. Esos cristianos necios, 11 de setembro de 2014. Disponível em: 
<http://w2.vatican.va/content/francesco/es/cotidie/2014/documents/papafrancesco_20140911_cristianos-necios.html>. Acesso em 10 de agosto de 2015.

, O nome de Deus é misericórdia. São Paulo: Planeta, 2016

Disponível

Palavras do Papa Francisco, Invocação pela paz, 8 de junho de 2014.

<http://w2.vatican.va/content/francesco/pt/speeches/2014/june/documents/papa-

francesco_20140608_invocazione-pace.html>. Acesso em 24 de junho de 2015.

, Papa fala sobre tesouros da Igreja, pobres $e$ infância http://papa.cancaonova.com/papa-fala-sobre-tesouros-da-igreja-pobres-e-infancia/ 6 de novembro de 2015. Acesso em 03 de julho de 2016.

\begin{tabular}{ccccc}
\multicolumn{4}{c}{, Primeira saudação do Papa Francisco. Benção Apostólica "Urbi et orbi", } \\
13 de
\end{tabular} <http://w2.vatican.va/content/francesco/pt/speeches/2013/march/documents/papafrancesco_20130313_benedizione-urbi-et-orbi.html >. Acesso em 30.04.2016.

Quando o Senhor chora, 06 de fevereiro de 2014. Disponível em: $<$ http://w2.vatican.va/content/francesco/pt/cotidie/2014/documents/papafrancesco_20140206_meditazioni-35.html>. Acesso em 04 de julho de 2016.

, Santa Missa com os seminaristas, noviços, noviças e quantos estão em caminhada vocacional, 07 de julho de 2013. Disponível em: <http://m2.vatican.va/content/francesco/pt/homilies/2013/documents/papafrancesco_20130707_omelia-seminaristi-novizie.html>. Acesso em 04 de julho e 2016.

Santa Missa com os novos cardeais, 23 de fevereiro de 2014. Disponível em: <http://w2.vatican.va/content/francesco/pt/homilies/2014/documents/papafrancesco_20140223_omelia-nuovi-cardinali.html>. Acesso em 03 de julho de 2016.

Santa Missa de Crisma, 17 de Abril de 2014. Disponível em: <http://w2.vatican.va/content/francesco/pt/homilies/2014/documents/papafrancesco_20140417_omelia-crisma.html>. Acesso em 01 de julho de 2016.

$\begin{array}{ccc}\text { - Santa Missa pelas vítimas dos naufrágios. Viagem a Lampedusa, } 08 \mathrm{de} \\ \text { julho } & 2013 . & \text { Disponível }\end{array}$ $<$ https://w2.vatican.va/content/francesco/pt/homilies/2013/documents/papafrancesco_20130708_omelia-lampedusa.html>. Acesso em 28 de maio de 2015).

, Solenidade do Natal do Senhor, 24 de dezembro de 2014. Disponível em: <http://w2.vatican.va/content/francesco/pt/homilies/2014/documents/papafrancesco_20141224_omelia-natale.html>. Acesso em 30 de junho de 2016. 
, Viagem Apostólica a Cuba, 20 de setembro de 2015. Disponível em: $<$ https://w2.vatican.va/content/francesco/pt/homilies/2015/documents/papafrancesco_20150920_cuba-omelia-la-habana.html>. Acesso em 01 de julho de 2016.

$\begin{array}{ccc}\text {, Vigília de oração por ocasião do Jubileu da Divina Misericórdia, } 02 \mathrm{de} \\ \text { abril } & 2016 . & \text { Disponível }\end{array}$ <https://w2.vatican.va/content/francesco/pt/speeches/2016/april/documents/papafrancesco_20160402_veglia-preghiera.html>. Acesso em 01 de julho de 2016.

, Vigília de pentecoste com os movimentos eclesiais, 18 de maio de 2013.

Disponível

em

<http://w2.vatican.va/content/francesco/pt/speeches/2013/may/documents/papafrancesco_20130518_veglia-pentecoste.html>. Acesso em 11 de junho de 2015

Disponível

Vigília de Pentecostes com os movimentos eclesiais, 18 de maio de 2013.

<http://w2.vatican.va/content/francesco/pt/speeches/2013/may/documents/papafrancesco_20130518_veglia-pentecoste.html>. Acesso em 01 de julho de 2016).

- Visita à FAO por ocasião da II Conferência Internacional sobre a alimentação, 20 de novembro de 2014. Disponível em: <http://w2.vatican.va/content/francesco/pt/speeches/2014/november/documents/p apa-francesco_20141120_visita-fao.html>. Acesso em 30 de junho de 2016.

_. Visita ao "Centro Astalli" de Roma para a assistência aos refugiados, 10 de setembro de 2013. Disponível em: <https://w2.vatican.va/content/francesco/pt/speeches/2013/september/documents/ papa-francesco_20130910_centro-astalli.html>. Acesso em 03 de julho de 2016.

, Visita apostólica ao Brasil por ocasião da XXVIII Jornada Mundial da Juventude. Encontro com o Episcopado Brasileiro, 27 de julho de 2013. Disponível

em:

<https://w2.vatican.va/content/francesco/pt/speeches/2013/july/documents/papafrancesco_20130727_gmg-episcopato-brasile.html>. Acesso em 25 de maio de 2015 .

, Visita pastoral à região de Molise, Italia, 05 de julho de 2014. Disponível em: <https://w2.vatican.va/content/francesco/pt/homilies/2014/documents/papafrancesco_20140705_molise-omelia.pdf $>$. Acesso em 02 de maio de 2015.

FRANKL. E. V., Em busca de sentido. Rio de Janeiro. Vozes, $34^{\circ}$ edição.

GEVAERT, J., Male e sofferenza interrogano. Torino: Elledici, 2000.

HUMMES, C., Ano Santo da Misericórdia. Um Jubileu extraordinário. São Paulo: Paulus, 2015.

JOÃO PAULO II, Universi Dominici Gregis, Constituição Apostólica Acerca da Vacância da Sé Apostólica e da Eleição do Romano Pontífice, 22 de fevereiro de 
1996. Disponível em: $<$ http://w2.vatican.va/content/john-paulii/pt/apost_constitutions/documents/hf_jp-ii_apc_22021996_universi-dominicigregis.html >). Acesso em 10 de julho de 2016.

INSTITUTO HUMANITAS UNISINOS. "Esta é a intervenção magistral do cardeal Bergoglio no pré-Conclave”, 26 de março de 2013. Disponível em: $<$ http://www.ihu.unisinos.br/noticias/518772-esta-e-a-intervencao-magistral-docardeal-bergoglio-no-pre-conclave>. Acesso em 15 de maio de 2016itutions/documents/hf_jp-ii_apc_22021996_universi-dominici-gregis.html>). Acesso em 10 de julho de 2016.

KASPER, W., Papa Francesco. La rivoluzione della tenerezza e dell'amore. Brescia: Queriniana, 2015, pp. 15-17).

Testimone della misericordia. Il mio viaggio com Francesco. Milano: Garzanti, 2015.

PIQUÉ, E., Papa Francisco: vida e revolução. São Paulo: LeYa, 2014, pp. 32$33)$.

RADIOVATICANO, Serviço Sacerdotal Noturno de Urgência recebe Mensagem do Papa. Disponível em: 〈http://br.radiovaticana.va/news/tags/servi\%C3\%A7o>. Acesso em14 de agosto de 2015.

RIBEIRO, A.A., A simplicidade do Papa Francisco em 13 gestos. In: Aletéia, 22 de março de 2013. Disponível em: <http://pt.aleteia.org/2013/03/22/asimplicidade-do-papa-francisco-em-13-gestos/>. Acesso em 01 de junho de 2016.

RODRIGUES, A. H., CORONATO, M., Muitos homens correm ao ver um filho com deficiência diz Olivia Byington, 26 de junho de 2016. Época Globo. Disponível em: <http://epoca.globo.com/vida/noticia/2016/06/muitos-homenscorrem-ao-ver-um-filho-com-deficiencia-diz-olivia-byington.html >. Acesso em 27 de junho de 2016.

SELI, A.; MARTELANC, K., Come incontrare l"altro. La consulenza psicosociale. Milano: Paoline, 2012.

SOCCI, A., In: Lo Straniero. Il blog di Antonio Socci. Disponível em: $<$ http://www.antoniosocci.com/la-lettera-che-mi-ha-scritto-il-papa-su-la-profeziafinale-e-la-mia-risposta/>. Acesso em 17 de junho de 2016).

La profezia finale. Lettera a Papa Francesco sulla Chiesa $i$ tempo di Guerra. Milano: Rizzoli, 2016, p. 91-92). 2014.

Non è Francesco. La chiesa nella grande tempesta. Milano: Mondadori, 
SPADARO, A., A proposta do Papa Francisco. O futuro rosto da Igreja. São Paulo: Loyola, 2013.

VANIER J., Signs ot times. Seven paths of hope for a troubled world. London: Darton, Longman and Todd, 2013, ebookkindle.

Quotes by Jean Vanier. Disponível em:

<http://www.goodreads.com/quotes/1743689-the-cry-for-love-and-communionand-for-recognition-that>. Acesso em 25 de junho de 2016. 